Center for the Advancement of Sustainability Innovations

\title{
Sustainability Indicators for the Army Installation Management Command
}

Chris C. Rewerts, Michelle J. Hanson, David A. Krooks,

March 2011

Gary G. Gerdes, Michael R. Kemme, and William T. Brown

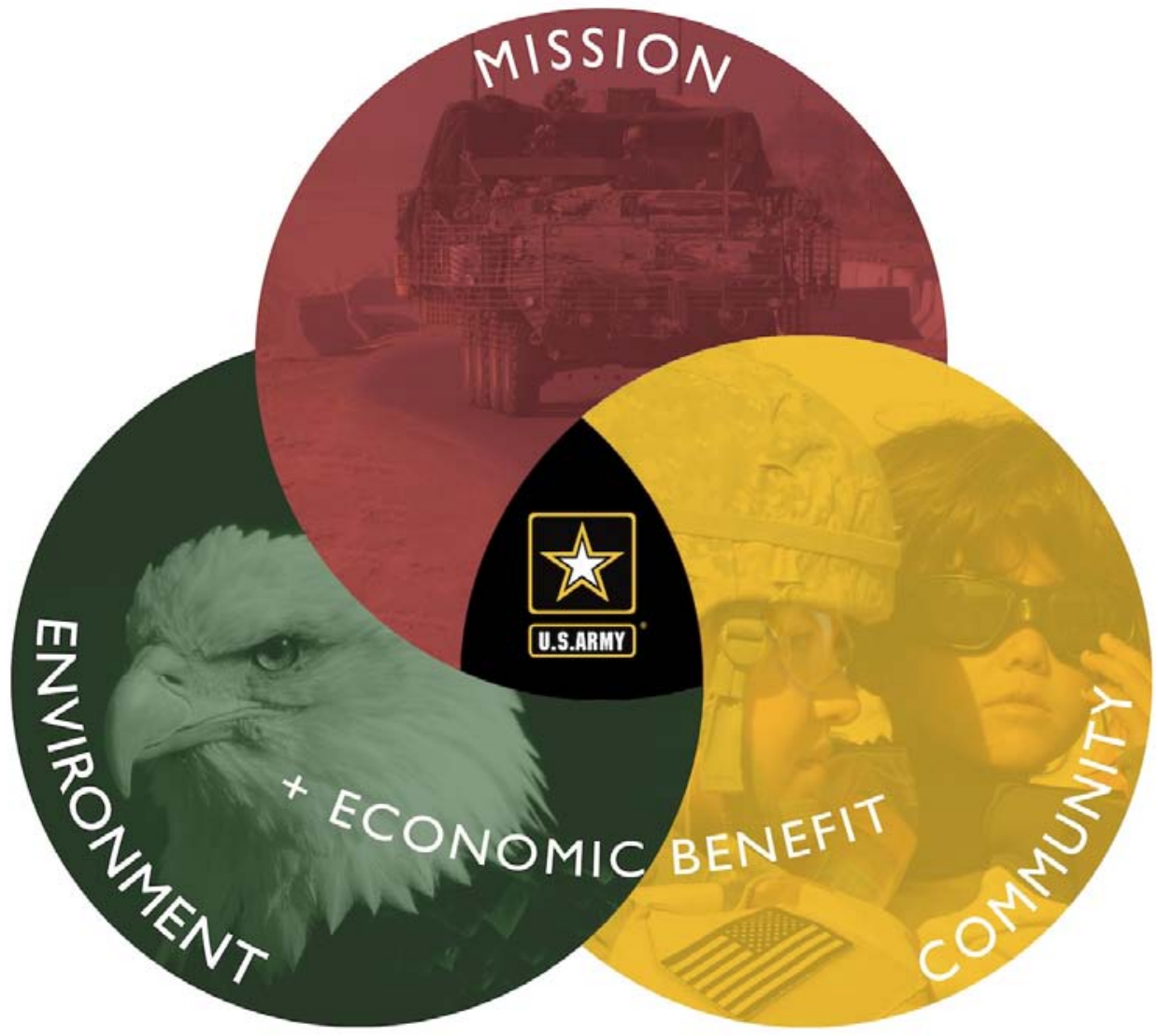





\section{Sustainability Indicators for the Army Installation Management Command}

Chris C. Rewerts, Michelle J. Hanson, David A. Krooks, Gary G. Gerdes, Michael R. Kemme, and William T. Brown

Construction Engineering Research Laboratory (CERL) U.S. Army Engineer Research and Development Center 2902 Newmark Dr.

Champaign, IL 61822-1076

Final Report

Approved for public release; distribution is unlimited.

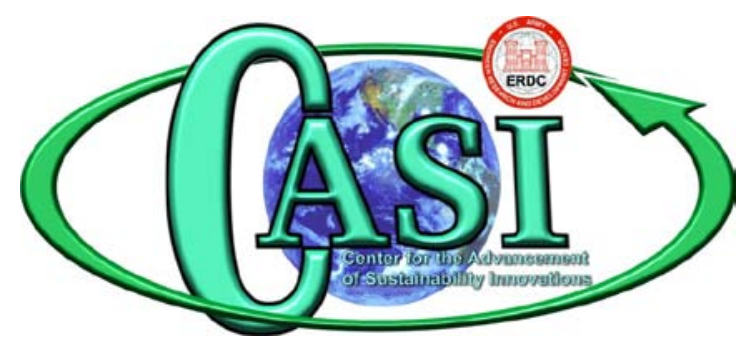

https://casi.erdc.usace.army.mil

Prepared for U.S. Army Installation Management Command

Under Work Unit BK9414 


\begin{abstract}
This study addresses indicators of sustainability. Such indicators differ from both sustainability goals and plans, and even from the implementation of actions that are believed likely to enhance sustainability. The indicators developed during this study are intended as direct measures of sustainability. The attributes of ideal indicators of sustainability are discussed. A set of indicators is defined that satisfy the criteria represented by those attributes. This ideal set of indicators is then confronted with Army data that might be used to derive values for the indicators. A set of six indicators and data sources is proposed for use by both the installations that are part of the U.S. Army's Installation Management Command (IMCOM) and by the Command itself.
\end{abstract}

DISCLAIMER: The contents of this report are not to be used for advertising, publication, or promotional purposes. Citation of trade names does not constitute an official endorsement or approval of the use of such commercial products. All product names and trademarks cited are the property of their respective owners. The findings of this report are not to be construed as an official Department of the Army position unless so designated by other authorized documents. 


\section{Executive Summary}

The United States Army Installation Management Command Headquarters (HQ IMCOM) tasked the Center for Advancement of Sustainability Innovations (CASI) with the creation of a set of indicators that would reveal the level of sustainability at each of its installations. The approach taken by CASI to develop this set of indicators involved the steps given here:

1. Determine the attributes of ideal indicators.

2. Define a set of indicators that had the desired attributes.

3. Compare the indicators with the metrics and goals developed by other efforts and refine the list as necessary.

4. Delineate the sources of data to be used to generate the indicator's value.

The ideal indicators were determined to have the attributes listed here, and a list of preliminary indicators was developed that meet these criteria.

- Indicators must measure sustainability, rather than merely quantify practices or actions that might be implemented as means of attaining sustainability.

- Indicators should represent elements directly related to mission.

- Indicators should report sustainability as a rate.

- Indicators should be independent of possible fluctuations in operations tempo (OPTEMPO), such as units deploying.

- Indicators should be applicable to any IMCOM installation.

- Indicators need to encompass the entire installation, fence line to fence line.

- Indicators should be easy to understand and should show status simply and clearly.

- Data must be readily available from which to derive the indicator's value.

In order to expose any deficiencies, those preliminary indicators were compared to metrics included in other approaches. The intention was to establish whether other approaches addressed a topic or topics important enough to require us to substitute it for one or more members of our set of 
possible indicators. Appendix A reproduces tables that exhibit the comparisons between our approach and the following five other approaches.

- The Tri-Services Sustainable Communities Scorecard

- The SERDP-funded report by Alan Atkinson, David Berry, and Lee Hatcher (2009) entitled Sustainability Assessment of a Military Installation: A Template for Developing a Mission Sustainability Frame-work, Goals, Metrics, and Reporting System

- The College Sustainability Report Card

- Executive Order (EO) 13514, Federal Leadership in Environmental, Energy, and Economic Performance, 5 October 2009

- The Army Sustainability Campaign Plan

The major outcome from comparisons between these documents and the preliminary set of installation sustainability indicators was the addition of an indicator (waste) that captures efforts toward the sustainable management of material resources. A proposed metric focused on infrastructure was deleted. What made the deletion of the infrastructure metric possible is the premise that any positive changes that an installation makes in the management of its infrastructure will result in improved performance against the water, energy, land, and waste indicators.

Ultimately, six installation sustainability indicators were selected, as defined here.

1. Water: water needed compared to water available

2. Energy: fossil fuel energy used per person

3. Waste: total cost per person of waste going to final disposal

4. Land: ratio of area of training land needed to accomplish the mission to area of training land available

5. Economic Impact: installation payroll compared to regional gross domestic product

6. Well-Being: installation's overall score from the dashboard developed by the Well-Being Division in Army G1 (Personnel). ${ }^{1}$

The indicators are designed to give each IMCOM installation a view of its own sustainability that is as straightforward as possible. The indicators are designed to allow HQ IMCOM to make informed decisions regarding sustainability efforts. This handful of indicators is intended to give as clear a

1 The Well-Being indicator has not been finalized, pending G1 efforts to develop metrics in this area. 
picture of sustainability as possible and to reveal trends at the installation, region, and enterprise levels.

The indicators offer a unique approach to monitoring sustainability. Many sustainability approaches merely aim at inspiring frugality. Others prescribe arbitrary numerical goals that are assumed (but not necessarily demonstrated) to result in improved sustainability. Still others merely tabulate a group of steps that might lead to enhanced sustainability.

The indicators proposed here are intended instead as direct measures of sustainability, such that an improvement in a given indicator's value over time actually demonstrates an improvement in sustainability. In short, this approach is unique because it sets out to answer the questions, "How sustainable are we?" and "Which way are we trending?" For example, a decrease in fossil fuel use shows an improvement in an installation's sustainability by directly correlating to a decrease in consumption of a finite and critical resource and a decrease in greenhouse gas emissions.

Furthermore, the set of indicators is broad-based and intended to address the sustainability issues vital to enduring Army mission success. The individual indicators also are easily understood and communicated, even by laypersons whose interest in sustainability might range from moderate to nonexistent. Perhaps most importantly, the indicators do not dictate what choices installations must make on their journey to improved sustainability. Instead, an installation is free to implement those actions most appropriate to its unique natural, economic, and cultural environments. The simplicity and breadth of the indicators provides the freedom to encourage systems thinking that is creative and crosses traditional domains.

Data that support many of the installation sustainability indicators are found in Installation Status Report - Natural Infrastructure (ISR-NI), Army Energy and Water Reporting System (AEWRS), and Solid Waste Annual Reporting (SWAR) system. It is expected that these data (and more) will be available in the Army's Strategic Management System (SMS). It is therefore expected that SMS will be the home for the installation sustainability indicators so that they ultimately can be of use not only to IMCOM and its installations, but also to the Army as a whole. 


\section{Table of Contents}

Executive Summary ....................................................................................................... iii

List of Figures and Tables ...........................................................................viii

Preface

Unit Conversion Factors .........................................................................................

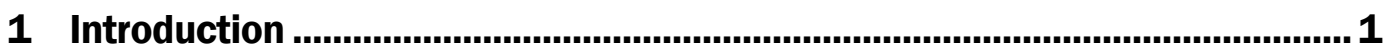

1.1 Background .........................................................................................

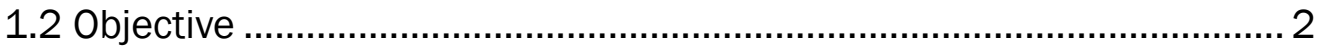

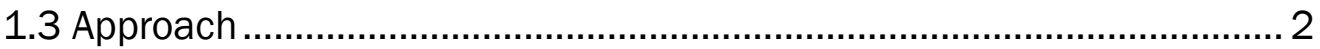

1.4 Mode of technology transfer ........................................................ 2

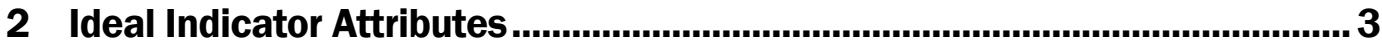

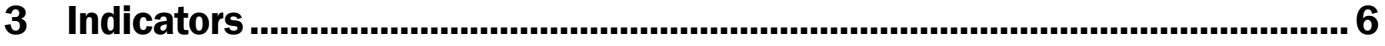

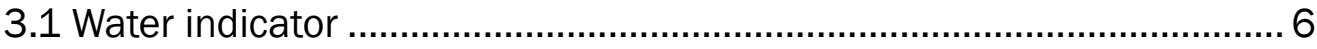

3.2 Energy indicator ......................................................................... 8

3.3 Waste indicator ..........................................................................

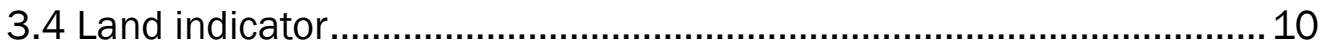

3.5 Economic impact indicator .......................................................... 11

3.6 Well-being indicator ...................................................................... 12

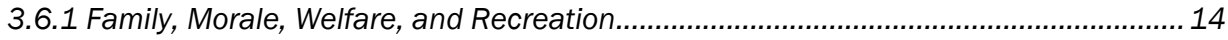

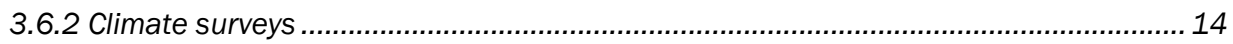

3.6.3 The Army Family Covenant .................................................................................... 14

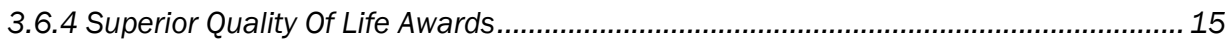

3.6.5 Army recruitment and retention rates........................................................................ 15

3.6.6 The Installation Management Campaign Plan and Quality of Life ................................ 16

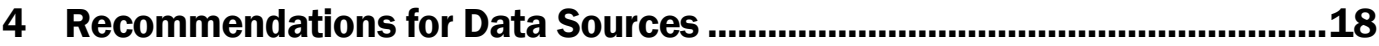

4.1 Water indicator ............................................................................ 18

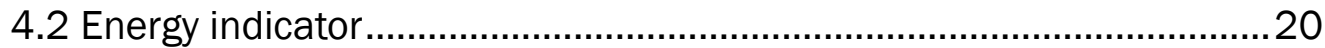

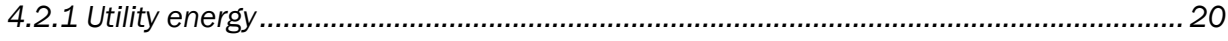

4.2.2 Army civilian fleet vehicle fuel consumption ............................................................. 23

4.2.3 Army tactical vehicle fuel consumption ....................................................................... 23

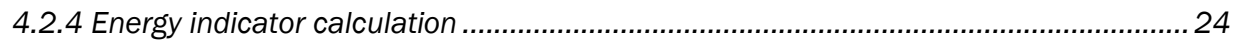

4.3 Waste indicator ......................................................................... 25

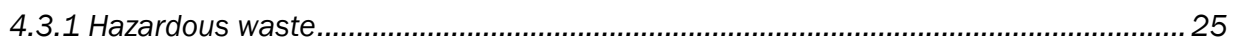

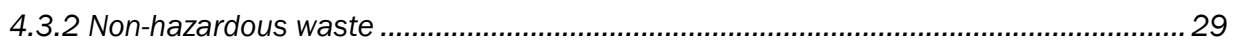

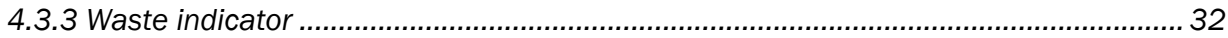




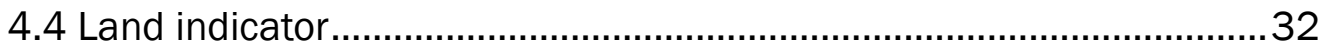

4.5 Economic impact indicator ...................................................................33

4.6 Well-being indicator ......................................................................... 35

4.7 Army Strategic Management System ............................................... 37

5 Comparison of Approaches for Capturing the Level of an

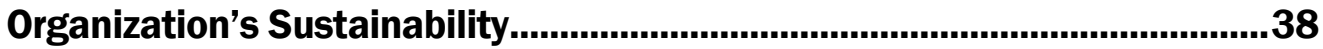

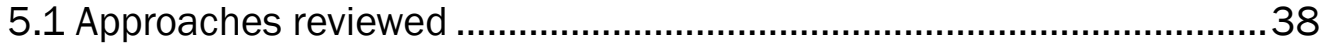

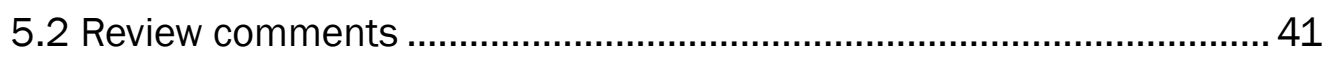

5.2.1 The Tri-Services Sustainable Communities Scorecard ............................................... 41

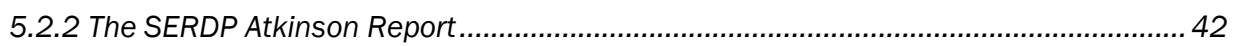

5.2.3 The College Sustainability Report Card....................................................................... 43

5.2.4 Executive Order 13514, Federal Leadership in Environmental, Energy, and Economic Performance, 5 October 2009......................................................................... 43

5.2.5 Army Sustainability Campaign Plan ........................................................................... 44

5.3 Consequences of the comparisons....................................................44

6 Conclusions and Recommendations......................................................46

Appendix A: Approaches Compared ..................................................................49

Appendix B: Installation Strategic Sustainability Planning (ISSP)

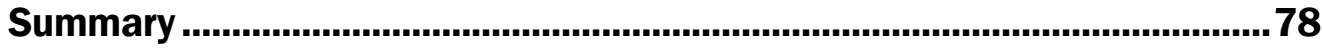

REPORT DOCUMENTATION PAGE......................................................... 103 


\section{List of Figures and Tables}

\section{Figures}

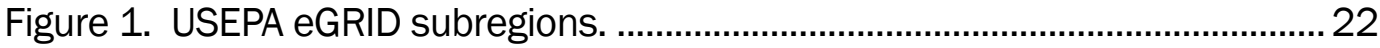

Figure 2. Section 8 of Fort Lewis's SWARWeb comprehensive report for FY09

\section{Tables}

Table 1. Water indicator example data as it would have been extracted from the Installation Status Report - Natural Infrastructure.

Table 2. FY08 Utilities by product report for Fort Hood, Texas (data source: AEWERS).

Table 3. Fuel consumption calculation example information from the OSMIS Aviation Commodity Group for Fort Hood during FY08.

Table 4. Energy consumption from fossil fuel use at Fort Hood during FY08.

Table 5. AE - Generator DoDAAC/HIN, Pickup DoDAAC Summary Report column descriptions.

Table 6. Generator DoDAAC/HIN, Pickup DoDAAC Summary Report for FY09 at Fort Lewis.

Table 7. Example hypothetical training schedule.

Table 8. Army installations with the borders of regional and micro MSAs. 


\section{Preface}

This study was conducted for the U.S. Army Installation Management Command (IMCOM) under Project Number BK4914, "Analysis of Installation Sustainability Program Goals for IMCOM Futures Strategies". The IMCOM technical monitor was Mr. Matthew Barden, Program Analyst, IMCOM Strategic Planning Division.

The work was performed by the Land and Heritage Conservation Branch $(\mathrm{CN}-\mathrm{C})$ of the Installations Division $(\mathrm{CN})$ at the Engineer Research and Development Center- Construction Engineering Research Laboratory (ERDC-CERL). Dr. Christopher M. White was Chief, CEERD-CN-C; Dr. J ohn Bandy was Chief, CEERD-CN; and Mr. William D. Goran was Technical Director for Sustainable Programs and Director of the Center for Advancement of Sustainability Innovations (CASI). The Deputy Director of ERDC-CERL was Dr. Kirankumar V. Topudurti and the Director was Dr. Ilker R. Adiguzel.

The Commander and Executive Director of ERDC was COL Kevin J . Wilson, and the Director of ERDC was Dr. J effery P. Holland. 


\section{Unit Conversion Factors}

\begin{tabular}{|l|c|l|}
\hline Multiply & By & To Obtain \\
\hline acres & $4,046.873$ & square meters \\
\hline British thermal units (International Table) & $1,055.056$ & joules \\
\hline gallons (U.S. liquid) & $3.785412 \mathrm{E}-03$ & cubic meters \\
\hline pounds (mass) & 0.45359237 & kilograms \\
\hline
\end{tabular}




\section{Introduction}

\subsection{Background}

The U.S. Army is a leader and innovator in sustainability. About 2000, the Army Forces Command (FORSCOM) began the Installation Strategic and Sustainability Planning (ISSP) effort. This effort engaged installations and their surrounding stakeholder communities in identifying a range of goals and objectives to advance sustainability within the Army. The initial efforts of installations in strategic sustainability planning were affirmed and strengthened as Army leadership presented a sustainability vision in 2004 with the Army Strategy for the Environment, ${ }^{2}$ which introduced the concept of the "Triple Bottom Line: Mission, Environment, and Community." In 2008, the first annual, Army-wide sustainability report was published. ${ }^{3}$ None of these efforts were required by policy or regulation; instead, the Army saw sustainability as something important enough to its mission to take the initiative.

The Army continues to seek innovations on its path to sustainability while learning from its previous efforts. For instance, over 30 installations have implemented ISSPs. Unfortunately, this bottom-up approach has created a situation in which installations have established various sets of noble though possibly unattainable goals. ${ }^{4}$ Army Installation Management Command (IMCOM) must now determine how to implement sustainability practices and infrastructure at installations and how to enhance sustainability within the Army.

To enhance Army sustainability, IMCOM needed the capability to determine how its available resources could best be used. To do this, IMCOM decided on an approach that would use a small set of carefully chosen indicators as a management tool to quantify installation sustainability and

\footnotetext{
2 U.S. Army, 2004. Available at http://www.asaie.army.mil/Public/ESOH/doc/ArmyEnvStrategy.pdf (last accessed 19 September 2010)

3 U.S. Army, 2007. “Sustainability Report 2007”, Available at http://www.aepi.army.mil/docs/FINALArmySustainabilityReport2007.pdf (last accessed 19 September 2010)

4 Lachman, B., E. Pint, G. Cecchine, and K. Collaton. 2009. “Developing Headquarters Guidance for Army Installation Sustainability Plans in 2007". RAND Corporation Report.

http://www.rand.org/pubs/monographs/MG837/ (last accessed 8 February 2010).
} 
begin to answer the question, "How sustainable are we?" Unlike ISSP goals that were defined independently at the installation level and were not comparable across installations, the installation-level set of indicators would be designed to allow the comparison of relative sustainability states and priorities across the IMCOM organization. The installation-level indicators could also roll up to the Army level to provide a more informed reporting of trends in the Army's annual sustainability report, while better informing installation-level ISSP goal setting.

\subsection{Objective}

The objective of this work was to develop a set of five to seven sustainability indicators for IMCOM's use at both the enterprise and installation levels. The indicators would measure progress toward sustainability that was due to the implementation of policy and other initiatives. While it may not be possible yet to quantify sustainability completely, the indicators are to be used as a relative or comparative measure of sustainability. Using available data, this initial set of indicators allows an organization to begin to answer the question, "How sustainable are we?"

\subsection{Approach}

Our development of a set of installation sustainability indicators has followed the path outlined here.

1. Define the attributes of ideal indicators. Given the small number, the set of indicators needs to cover the spectrum of sustainability and generate a big picture.

2. Prepare a list of ideal indicators that have the desired attributes.

3. Compare the indicators with other lists of sustainability metrics.

4. Discover and document sources of data that have the greatest ability to generate the indicators' value.

5. Negotiate between the ideal indicators and available data sources to determine practical indicators closest to theideal.

\subsection{Mode of technology transfer}

This report will be made accessible through the World Wide Web (WWW) at URL: http://libweb.wes.army.mil/uhtbin/hyperion/CERL-TR-11-11.pdf. 


\section{Ideal Indicator Attributes}

To accomplish the objective, the set of installation-level sustainability indicators should simply and broadly answer the question, "How sustainable are IMCOM installations?" in the areas of greatest importance to fulfilling the Army mission. To do that, ideally each indicator should have the attributes listed below.

- Indicators must measure true sustainability rather than quantify a practice or action used to enhance sustainability. Indicators need to focus on the ends (true sustainability), not the means to achieve those ends.

- Indicators should represent elements directly related to mission.

- Indicators should report sustainability as a rate.

- Indicators should be minimally influenced by fluctuations in operational tempo (OPTEMPO), such as units deploying.

- Indicators should be applicable to any IMCOM installation, making it possible to compare sustainability among all installations and combine indicators to look at the trends across the enterprise.

- Indicators need to encompass the entire installation, fence line to fence line; thus, the indicators should represent aspects of sustainability that can be affected by installation and IMCOM decisions and actions.

- Indicators should be easy to understand and should show sustainability status and trends simply and clearly.

- Indicators' values should be derived from data that is readily available.

To further elaborate on the first bullet point above, an indicator should not single out specific efforts that improve sustainability. Rather, an indicator should measure an aspect of sustainability that can be improved by the implementation of sustainable actions or practices. For example, it is better to monitor fossil fuel usage than the amount of renewable energy used. Using renewable energy is one of many options that could reduce dependency on fossil fuel. Monitoring sustainability rather than a single action or practice allows the installation freedom to implement measures appropriate to its location. Such implementation creativity and innovation will be best promoted by allowing flexibility whenever possible at the installation level. 
The attributes of good indicators suggest that an indicator should be a ratio that represents a specific sustainability domain (energy, water, etc.) and then relates that domain to a common point of reference (per person, per square foot, etc.). When properly defined, each indicator is a metric that measures sustainability across installations and is independent of installation size or OPTEMPO.

For some indicators, the best resource usage rate is "per person." The perperson denominator addresses the impact of all who live and/ or work on the installation. We recommend that the total population served, as reported in the Army Stationing and Installation Planning (ASIP) database, be used as the denominator to obtain a "per person" measure.

Another valuable resource ratio is to compare the amount of a resource that will always be available versus the amount of that resource an installation needs to sustain its mission. In this case, the level of sustainability improves as the value of this ratio becomes larger.

An indicator should be easy to understand. It should be like the gas gauge on an automobile dashboard that does not need to tell the driver the chemistry of combustion or the mechanics of using it for propulsion, but simply how much fuel is available. The driver easily knows what to do with the information.

To date, many sustainability efforts have focused on goals such as reduction of energy or water use. Without knowing the state of sustainability; such goals are only attempts at inspiring frugality. Sustainability means operating within our means. So-called sustainability goals often imply or state a prescriptive means to obtain them. In contrast, the design of the indicators outlined here may better empower Army personnel to employ systems thinking that will develop innovative processes and methods to support the mission.

An indicator must be based on information that is currently reported. Large amounts of information and data are already available to IMCOM via the Installation Status Report (ISR), the Army Energy and Water Reporting System (AEWRS), and other systems. The derivation and updating of the indicator values should require only a small amount of effort on the part of IMCOM personnel. Ideally, there will be no new reporting requirements placed on the installations in order to measure sustainability. 
There is a tendency to focus on environmental compliance when establishing metrics for sustainability. Sustainability is about the stewardship of natural and human resources. While environmental compliance is certainly a tool of proper stewardship, it is not a measure of sustainability, nor is it the focus of any of the indicators developed as part of this effort. 


\section{Indicators}

Our concise group of indicators has been defined in such a way that the attributes discussed in Chapter 2 affected the indicators' definitions as closely as possible. Those definitions with brief explanations are below.

1. Water: water needed/ water available (maximum amount needed by the installation versus the amount available)

2. Energy: fossil fuel energy (BTU)/ person (fossil fuel energy used per person)

3. Waste: total cost of waste going to final disposal per person (cost of solid waste + hazardous waste + construction and demolition waste disposal per person)

4. Land: area of training land available/ area of land needed (acres available versus acres required to accomplish the installation's mission)

5. Economic Impact: installation payroll (\$)/regional GDP (ratio of installation payroll to economic metric of the local community)

6. Well-Being: overall score from dashboard developed by the Well-Being Division in Army G1, Personnel.

The value of each indicator is not meaningful in isolation; it becomes meaningful when used in comparison to previous values and/ or in comparison to other installations. The following sections discuss each of the aboveindictors in detail.

\subsection{Water indicator}

Water is critical to the Army's operations and mission because it is essential for human survival. Each installation must have a sustainable source of water and an appropriate infrastructure to deliver water where it is needed. The ideal indicator for water sustainability should take into consideration water availability and water usage. Most importantly, the amount of water that is available must always be greater than the amount of water that is needed if the installation is to be considered sustainable.

Globally, water is not a limited resource; two-thirds of Earth is covered with it. However, water is often a resource that is limited at the installation level. Thus the sustainability aspect of water is not a function of water being a finite resource, as it is for fossil fuel, but rather it is related to the 
economics of obtaining water from the nearest source and then treating it. For instance, seawater is Earth's most plentiful source of water, but treating and transporting it long distances is usually not considered a viable option because of the high cost to do so. As a result, likely sources of water are normally surface fresh water or groundwater, both of which are limited in volume and of varying quality. As the cost of water goes up, alternative sources such as treated wastewater and collected stormwater become economically viable. However, these alternative sources do not actually become available until the necessary delivery infrastructure is in place. In order to evaluate the utility of alternate sources, IMCOM needs an indicator that will capture the notion of "available water."

The research team considered using the installation's cost of water as the sustainability indicator for water. The underlying assumption was that the availability of water would be reflected in its cost. The cost of water per person could then be used by IMCOM to determine where water conservation measures are most appropriate across the Army. A disadvantage to using cost as an indicator is that it tends to reflect current availability, but might not reflect long-term availability particularly well. Also, the cost for water currently is not reported to IMCOM, thus undermining using cost as an indicator. Since cost is not an effective indicator, indicators that measured availability were evaluated.

Measuring the availability of water is complex. Surface waters are limited by weather cycles, and groundwater is limited by recharge rates. Population growth also limits the long-term availability of water.

The Installation Status Report-Natural Infrastructure (ISR-NI) has standards that address the amount of water available versus the amount of water being used at an installation. From this, we can derive the installation sustainability indicator for water as the ratio of peak water usage to minimum water available. Chapter 4 discusses in detail the use of ISR-NI data for water availability.

Many installations are in areas where the water resources are already limited and require local or regional management. The water indicator will clearly reveal where use is relatively unsustainable, so that IMCOM can direct its sustainability efforts where they are most needed. The water indicator also allows an installation the flexibility to implement recycling, conservation, and other measures appropriate to its specific context. 
As the value of this indicator increases, water sustainability decreases. And of course as the value decreases, water sustainability increases. The numerical value of the water indicator must be kept below 1.0 in order for water to be a sustainable commodity (i.e., water usage must not exceed water availability.

\subsection{Energy indicator}

By itself, energy use is not a sustainability issue. Similar to its total water resources, the Earth is awash in sustainable energy sources that are yet to be fully exploited. However, the currently used primary sources of energy are not sustainable.

Fossil fuel consumption is the most unsustainable current use of energy. Fossil fuel is a finite world resource and also is the most significant source of greenhouse gas emissions on Army installations. For these reasons, the energy indicator is defined as: energy (measured in BTUs) as derived from the amount of fossil fuel used per person.

By defining the energy indicator in this way, the installation is free to reduce fossil fuel consumption in a number of ways, such as through increased efficiency and/ or use of various types of renewable energy. The installation can choose the approach that is most cost-effective and suitable for its infrastructure. This definition does not constrain the installation to the implementation of specific technologies.

Additionally, the quantity of fossil fuel use is essentially an indicator of $\mathrm{CO}_{2}$ emissions. Thus, much of the data required for reporting greenhouse gas emissions can be used to calculate the energy indicator's value.

Military training and operations currently are dependent on energy derived from fossil fuels; thus, the energy indictor is directly related to mission fulfillment. Its critical nature is further supported by the existence of Army doctrine that addresses the logistics of providing liquid fossil fuel to support operations. ${ }^{5}$ Because fossil fuel is a finite world resource, monitoring its use and reducing dependency on it are essential to making the Army's mission sustainable.

${ }^{5}$ Army field manuals do not specifically address any other material resource except water. 
Reporting energy use is often limited to the amounts used in infrastructure and is normally reported as "per square foot." However, this measure does not represent total fossil fuel use that includes fossil fuel consumption by civilian fleet and tactical vehicles. An adequate indicator must include all fossil fuel use.

Even measuring total fossil fuel use would not offer an adequate indicator. Deployments have a significant impact on total energy use by dramatically decreasing the installation's resident population. If the indicator were to measure only total energy used without reference to population, or if it were to measure energy used per square foot, then it would falsely appear that significant improvement in energy efficiency had occurred, when it was caused merely by a temporary reduction in population. This false positive likely will not occur when the value of the energy indicator is calculated per person.

As the value of the indicator increases, the energy sustainability of the installation decreases. As the value of the indicator decreases, energy sustainability improves.

Data on Army energy use must be collected from several sources. Utility fossil fuel energy data can be collected from AEWRS, federal civilian vehicle fleet fossil fuel usage from the General Services Administration's (GSA) Federal Automotive Statistical Tool (FAST), and tactical vehicle fuel consumption from the Operating and Support Management Information System (OSMIS) relational database system.

\subsection{Waste indicator}

The waste indicator is defined as the cost per person to dispose of waste. The indicator's value will be the sum of final disposal costs for hazardous and non-hazardous wastes. That sum would also include costs to dispose of ash from incinerators and the disposal of construction and demolition waste.

When developing the waste indicator, two alternatives were considered for the numerator: cost and weight. Using weight as the measure tends to give a much greater importance to the minimization of non-hazardous waste disposal versus hazardous waste disposal. The per-pound cost to dispose of hazardous waste is normally much higher than the cost to dispose of non-hazardous waste, yet the total amount of hazardous waste generated 
is much smaller than the amount of non-hazardous waste. It was assumed that the incentives to limit the disposal of hazardous and non-hazardous wastes should be as near equal as possible. Therefore, total cost was chosen as the numerator for this indicator because its use tends to equalize the incentive to minimize the disposal of both hazardous and nonhazardous wastes.

As with energy, the value of the waste indicator is not meaningful except for the purpose of comparisons to previous values and to other installations. Obviously, the goal will be to minimize the cost per person to dispose of waste at an installation. Minimizing cost encourages an installation to implement cost-effective measures to reduce its waste by methods such as recycling, reuse, reduction of packaging, energy recovery, product substitution, and composting. Because the indicator uses installation population as the denominator, its value is independent of population changes due to deployments.

Non-hazardous solid waste disposal cost data is being reported currently on the "Comprehensive Report" in the Solid Waste Annual Reporting (SWAR) system. Hazardous waste disposal costs can be obtained through a Defense Logistics Agency (DLA) Disposition Services database tool called the Environmental Reporting System (ERS).

\subsection{Land indicator}

An Army installation must have enough land available so that the training necessary to develop and maintain mission capabilities can be conducted. However, training land is often restricted by encroachment from nearby commercial and residential developments and by habitat requirements for threatened and endangered species. The Army Compatible Use Buffer (ACUB) system has been helpful in maintaining the availability of land on many installations.

The land indicator is defined as the ratio of the area of land needed to accomplish mission to the area of land actually available. Ideally, "land needed" would include all uses whether for maneuver training, structures, or industrial purposes. However, the amount of land supporting administrative and industrial use is trivial compared to the amount used for ranges. Thus, the land indicator can be limited to range land needed for maneuver training and weapons use. For the purpose of this indicator, 
"land needed" is defined as the area of range land necessary to accomplish all required training by the tactical units dependent on that land.

"Land available" takes into consideration any land lost due to range management requirements (e.g., controls related to habitat, noise or dust), and any land lost due to outside-the-fence influences (e.g., encroachment). When the ratio of land needed to land available has a value of 1.0 or less, an installation has at least as much land as it needs. A ratio greater than 1.0 indicates the installation cannot fully accomplish its training mission because it needs more land than it has available.

\subsection{Economic impact indicator}

The economic impact indicator is included to represent the elements of community and economics that are reflected in the Army's concept of Triple Bottom Line - Plus (Mission, Environment, Community, Economy), as given in the Army Sustainability Report (2007). An installation interacts with the local community in many ways, not the least of which is the direct economic impact the installation has on the local economy by providing jobs to civilians and payroll to soldiers who live in the community. In return, the community normally provides retail, entertainment, and professional services; infrastructure to access those services; and utility services for use by the installation's military and civilian populations. The natural financial and social interactions between the installation and the local community often generate more formal interactions between installation command and local governments. Communities also may become involved in cooperative efforts to provide services used by installation personnel.

An ideal economic impact indicator would measure the relative health of the overall relationship between an installation and its local community. Unfortunately, there are presently no metrics that objectively measure that relationship. For instance, good will and cooperation are important but not easily quantifiable. Economic impact, however, is more easily quantifiable.

An installation's economic impact on the surrounding community includes: (a) jobs created inside and outside the fence line, (b) dollars inserted into the local economy through local acquisition, and (c) taxes generated for local governments. The installation has the most control over the amount of money inserted into the local economy, through purchases 
and contracts with local vendors and through wages paid to military and civilian personnel at the installation. Quantifying local purchases might be a good measure of economic impact, were it not for Department of Defense (DoD) and Army policies that tend to centralize procurement, even of office supplies, for example. But for such policies, quantifying local purchases also would emphasize the sustainability principle of buying goods and services locally. Unfortunately, the amount of installation funding going toward the local economy does not appear to be reported or tracked.

Another possibility for an economic indicator is the effect wages paid to the military members and civilians have on the local economy. This effect can be measured by the ratio of total annual payroll to the regional gross domestic product (GDP). The economic indicator is then defined as: installation payroll (total population)/regional GDP. That ratio, or percentage, will tell HQ IMCOM the relative impact each installation has on the respective local economy. It also will indicate to HQ IMCOM the relative affect changes in mission or OPTEMPO have on the surrounding community. Using this measurement, the relative impact the installation has on the local economy, the greater the value of its economic indicator.

Data are available to support this indicator from two sources. The Bureau of Economic Analysis (BEA) provides data regarding regional GDP, and the human resources group within the Directorate of Resource Management should be able to provide payroll data.

\subsection{Well-being indicator}

..I sometimes feel like I live in a parallel universe. I sit through these briefings at the Pentagon, where I learn all about these great things that the Department of Defense is doing when it comes to family programs. But when I visit a base or a post and actually talk to military families, I sometimes hear a different story. (SECDEF Robert E. Gates ${ }^{6}$ )

The Army Mission is not sustainable without people. First and foremost is the well-being of soldiers and their families, plus that of Army civilians on the installation. Including well-being as an installation-level sustainability metric thus is important not only for the mission dimension of sustainabil-

\footnotetext{
6 Town Hall Meeting at Fort Riley, Kansas, on 8 May 2010. Available at: http://www.defense.gov/Transcripts/Transcript.aspx?TranscriptID=4622
} 
ity, but also for the community dimension. There is a continuum of possible indicators that starts with standard of living, moves through quality of life, and continues through well-being. First, "standard of living" normally includes measures such as income per person relative to poverty rates, and the access and quality of health care, education, services, and goods. Secondly, "quality of life" generally takes into account the material components in the standard of living but also considers less tangible life factors such as environmental quality, health, leisure, culture, and social life. Third on the continuum of indicators is "well-being" which is less involved with the outward aspects of people's lives and focuses on more inward and personal aspects such as physical, mental, and spiritual health.

Well-being, as defined by Army Command Policy: ${ }^{7}$

Army Well-being is the personal-physical, material, mental, and spiritual - state of the Army Family, including Soldiers (active, reserve, and guard), retirees, veterans, DA civilians, and all their Families, that contributes to their preparedness to perform and support the Army's mission. The focus of Army Well-being is to take care of our Army Family before, during, and after deployments.

It makes intuitive sense that promoting well-being on the installation will benefit the sustainability of the Army mission. Reduced stress would improve safety, workers would be more productive, soldier retention would be higher, and there would be benefits to the surrounding community that likely would result in increasing support of the Army installation as a neighbor. The difficulty, in terms of indicator development, is how to quantify and measure well-being.

A number of possible sources were considered for well-being metrics within the Army. There are many programs that focus on soldiers and/ or families; however, few result in quantifiable data.

7 US Army. 18 March 2008. Army Regulation 600-20, Chapter 3, Section 3-2, p 20. Available at http://www.apd.army.mil/pdffiles/r600_20.pdf 


\subsubsection{Family, Morale, Welfare, and Recreation}

The Family, Morale, Welfare, and Recreation (FMWR) function at installations is a well-being program that supports readiness by providing a variety of community, soldier, and family support programs, activities, and services. This variety includes social, fitness, recreational, educational, and other programs and activities that enhance installation life, foster soldier and unit readiness, promote physical and mental fitness, and provide a working and living environment that attracts and retains quality soldiers. The Army Regulation for FMWR, AR 215-1,8 states, "programs are prioritized based on their impact on readiness." Unfortunately, we have yet to find any metrics that quantify this impact.

\subsubsection{Climate surveys}

A potential source for well-being metrics could be organizational climate surveys, such as those conducted on behalf of the Army Deputy Chief of Staff, G-1; ${ }^{9}$ or by the Army Research Institute for Behavioral and Social Sciences (ARI). ${ }^{10}$ What is not known is how well such climate survey results might reflect the effect that the installation has on the morale and well being of the soldiers and civilians, and how any connections to well-

being can be made obvious. Furthermore, both groups conduct climate surveys only by authorized requests and do not release the results of the surveys except to the commander who requested them. Therefore, these surveys are not a potential source for well-being metrics that can be used across all installations.

\subsubsection{The Army Family Covenant}

The Army Family Covenant: Keeping the Promise ${ }^{11}$ was introduced Armywide in October 2007. It provides a compilation of information reported across the following areas of interest:

\footnotetext{
8 http://www.army.mil/usapa/epubs/215_Series_Collection_1.html (last accessed 6 July 2010)

9 For example, http://www.deocs.net/public/index.cfm (last accessed 6 July 2010)

10 http://www.hqda.army.mil/ari/about/index.shtml, specifically, see http://www.hqda.army.mil/ari/pdf/surveysandtransformation.pdf (last accessed 6 July 2010)

$11 \mathrm{~A}$ brochure is available for download at the Army Family Covenant homepage (accessed July 2010)
} 
- family programs and services

- health care

- soldier and family housing

- child, youth, and school services

- education, careers, and libraries

- recreation, travel, and BOSS (Better Opportunities for Single Soldiers)

- communities and marketplace

Although it does address topics of interest from the perspective of wellbeing, it is a compilation of success stories intended to articulate what the Army has done under each of the topic headings above. It is not a report against a specific plan or a specific program that establishes clearly defined measures of success.

\subsubsection{Superior Quality Of Life Awards}

In December 2010, the Office of the Secretary of the Army sought submissions for the third annual Superior Quality of Life Awards to installations. There are three awards, one each for a small, a medium, and a large installation. It was thought that the criteria used in selecting the winners of these awards might provide insight into an effective well-being indicator. While the criteria do include a category called "measurement of impact," the installation submitting its application must develop its own measurement method. Measurement methods are not provided by the submission website. ${ }^{12}$ Therefore, the award selection criteria were not helpful in defining the well-being indicator.

\subsubsection{Army recruitment and retention rates}

Both Army recruitment and retention are considered as possible indicators for quality of life or well-being, since the trending of either rate could reflect a relative change in perceived well-being. We found recruitment to be an Army-wide issue and one that is not reported at the installation level. Similarly, retention is not an issue over which the installation can exercise control. Even if a causal link between well-being and recruitment or retention could be argued, the lack of reporting or influence at the installation level makes them poor choices as metrics.

http://www.myarmyonesource.com/CommunitiesandMarketplace/ArmyFamilyCovenant/default.aspx

12 www.acsim.army.mil 


\subsubsection{The Installation Management Campaign Plan and Quality of Life}

The Installation Management Campaign Plan (IMCP) ${ }^{13}$ contains a number of references that might suggest metrics useful to quantifying well-being. For example, in the section entitled, "Soldier, Family and Civilian WellBeing," we find the statement saying, "The Army Comprehensive Soldier Fitness (CSF) initiative focuses on sustaining resilience in our Soldiers, Families and Civilians through individual assessment and planning across emotional, social, spiritual, family, and physical domains. It provides one tool to measure the effectiveness of the AFC [Army Family Covenant]." The keystone of the CSF is the global assessment tool (GAT), which allows the Soldier to assess him-/ herself "on the dimensions of emotional, spiritual, social, and family fitness."

The GAT ${ }^{14}$ is a survey that takes about 10-20 minutes to complete and, at the end, presents the taker with a rapid estimate of his/her individual fitness in the following four dimensions: emotional, spiritual, social, and family fitness. The same GAT website's welcome page indicates that the Soldier will be able to see individual performance in response to training, experience, and maturity. The website continues:

Additionally, beginning in FY 2010, the results will automatically develop an individualized profile to guide you through self-development training modules most appropriate for your stage and current level of performance in each dimension. The self-development training modules will provide you with real-time and interactive multi-media training...A complete transcript and record of the courses you complete will be stored in a database that allows you to display your training as a component of the Army Career Tracker.

According to ACSIM's website, 15 the program is intended to:

...develop and institute a holistic fitness program for Soldiers, families and Army civilians to enhance performance and build resilience [the ability to grow and thrive in the face of challenges and to bounce back from adversity]. As a result we will have an Army of balanced, healthy, self-confident

\footnotetext{
13 References to IMCP are to the Version 1.0 Draft, date March 2010. Version 2.0 (Installation Management Community Campaign Plan 2010-2017) was released October 2010.

14 See https://www.sft.army.mil/Protected/Secured/Welcome.aspx

15 See http://www.acsim.army.mil/readyarmy/ra_csf.htm
} 
people whose resilience and total fitness enables them to excel in an era of high operational tempo and persistent conflict.

The same website also indicates, "Soldiers will take the GAT every two years or 120 days following contingency operation deployments. The reserve-component Soldiers are also able to take the GAT every two years, and within 180 days following contingency operation deployments." The opportunity to participate in the GAT survey recently has been made available to Soldiers' family members and to DA civilians.

Although it does appear that the Army expects to roll up GAT scores to the Army level, it is unclear whether or not it would be possible to use any such results as a metric at the installation level. Additionally, none of the CSF sources we have reviewed (and referred to in this report) indicate anything more than that changes in scores over time will be available to individuals. Thus, we do not see any possibility for adding information from CSF to the IMCOM installation sustainability indicators.

The IMCOM Campaign Plan also mentions the following:

- a metric defined as percentage change in the Military Family Life Counselor contacts and referrals;

- a summary report prepared by the Suicide Prevention Task Force to which garrisons submit data; and

- an ISR standard for alcohol-related incidents.

It is likely that these metrics would only weakly support an installationlevel well-being indicator. Section 4.6 below contains the recommended course of action for developing a well-being indicator. 


\section{Recommendations for Data Sources}

Chapter 3 of this report introduces the concept of sustainability and explores possible ways to measure it in the Army. The process of refining the recommended sustainability indicators starts with exploring the data that might support them. The goal of that exploration is to find data that matches as closely as possible to the ideal indicator metrics, and, whenever possible, was collected by the Army itself. For purposes of trending the various indicators, it is imperative that these data sources also have a long life expectancy.

When considering sources of data that might support indicators, it is important to remember the data's original purpose was to measure something other than sustainability. The goal is to find the closest fit possible between the desired characteristics of the sustainability indicators and the available data. This will be an iterative process because first, an ideal indicator definition may change to fit better with available data and secondly, over time the use of indicators may demonstrate a need for new data or other parties may suggest data that previously was not found in the course of preparing this report. The sections below describe information sources for each of the indicators. Example data are included whenever possible.

As a general rule, all the data used in calculating the value of a given indicator must be taken from the same range of dates. For example, if data from 2008 were used to calculate the water indicator value, all data used to develop that indicator value must come from 2008. On the other hand, it is possible (but not significant) that the data ranges for individual indicators may vary. That is, if the most recent data for the water indicator come from 2008, it is not critical (and may not be possible) that the data underlying the energy indicator also come from 2008.

\subsection{Water indicator}

Data for the water indicator can be obtained from the Natural Infrastructure section of the ISR database system. The Natural Infrastructure section has a subcategory for Mission Support - Water - Potable Water and this subcategory includes eleven standards. One of these standards, MS310-3, reports the percentage of available potable water used (based on peak daily demand) versus its lowest availability in the previous three years. This 
measure is acceptable as the data source for this indicator for immediate use. However, the definition of "Total Available Water Supply" should be modified to consider long-term availability of water from its source. Other recommendations to correct the way water data are defined for input into ISR-NI series MS310 are in the Note below.

Calculating the water indicator will use the two data inputs for MS310-3: "Total Available Potable Water Supply" and "Total Water Used (Peak)." The water indicator will be a ratio of those two inputs. Table 1 (using notional data) shows an example of the water indicator values for four example installations.

Table 1. Water indicator example data as it would have been extracted from the Installation Status Report - Natural Infrastructure.

\begin{tabular}{|l|c|c|c|c|}
\hline \multirow{2}{*}{} & \multicolumn{4}{|c|}{ Installation } \\
\cline { 2 - 5 } & Fort X & Fort Z & Camp A & Camp B \\
\hline $\begin{array}{l}\text { Total Water Used Peak } \\
\text { (GPD) }\end{array}$ & $8,060,000$ & $9,000,000$ & $5,400,000$ & $5,500,000$ \\
\hline $\begin{array}{l}\text { Available Potable Water } \\
\text { Supply (GPD) }\end{array}$ & $16,050,000$ & $23,300,000$ & $6,000,000$ & $14,000,000$ \\
\hline Water Indicator & 0.50 & 0.39 & 0.90 & 0.39 \\
\hline
\end{tabular}

As seen in the above hypothetical example, Camp A is using the highest percentage of its available water supply. It would be concluded that IMCOM might consider prioritizing actions to improve water sustainability at such an installation.

As the value of this indicator increases, water sustainability decreases and as the value decreases, water sustainability increases. Water is a sustainable commodity when the numerical value of the ratio of the amount of water needed to the amount of water available is always kept below 1.0. A maximum acceptable value for this ratio of 0.5 has been set in the ISR-NI in order for an installation to achieve a "Green" rating.

Note: The input for "Total Available Potable Water Supply (Gallons)" is not meaningful as defined in the ISR-NI worksheet. Water stored in water towers should not be included in the quantity reported. The purpose of water towers is to provide a large volume of water for emergency purposes (e.g., fire fighting), and at some locations, to maintain a constant line pressure. Water stored in water towers is not used to meet average daily water 
demand. If is recommended that the definition of available potable water be corrected in the series of ISR-NI indicators for potable water. Further, "Total Available Water Supply" should be reported in gallons per day (GPD), so that the units of measure for that input match the units for "Total Water Used." Making these corrections to the definitions used in the ISR-NI Potable Water Standards will result in changes to the installation inputs, and possible result in changes to ratings.

\subsection{Energy indicator}

Energy consumption on an installation can be broken down into electrical energy usage, fossil fuel combustion for utility purposes (e.g., distributed and central heating/ cooling), fossil fuel combustion for military mobile sources, and fossil fuel combustion for federal civilian mobile sources. AEWRS contains information about both electrical energy consumption and fuel usage for utility purposes. FAST tracks vehicle fleet inventory, acquisition and disposal expenses, vehicle cost, miles driven, and fuel consumption. Tactical vehicle fuel consumption information can be found in OSMIS. The sections below will describe how energy information is collected for these categories by presenting example data for FY08 provided by Fort Hood, Texas.

\subsubsection{Utility energy}

Energy consumed at Fort Hood for utility purposes is shown in Table 2. The first section of the Utilities by Product report shows electrical energy consumption, and the second section shows natural gas consumption. No other fuels were reported in AEWERS for Fort Hood. AEWRS does not include renewable energy when utility energy consumptions are entered; thus, increased use of purchased or on-base renewable energy will lead to a reduction of the energy consumption values shown in Table 2 . The report indicates 1,136,165 MMBTU of electrical energy and 891,988 MMBTU of natural gas were consumed by Fort Hood in FY08. 
Table 2. FY08 Utilities by product report for Fort Hood, Texas (data source: AEWERS).

\begin{tabular}{|c|c|c|c|c|c|c|c|}
\hline \multicolumn{8}{|c|}{ UTILITIES BY PRODUCT } \\
\hline \multicolumn{6}{|c|}{27 August 2010} & \multicolumn{2}{|c|}{ Page 1 of 2} \\
\hline \multicolumn{8}{|c|}{ 48255 FORT HOOD } \\
\hline \multicolumn{8}{|c|}{ Units Are: MMBTUs } \\
\hline $\begin{array}{l}\text { Prod } \\
\text { Code }\end{array}$ & $\mathrm{FY}$ & Month & $\begin{array}{c}\text { Building } \\
\text { Consumed }\end{array}$ & $\begin{array}{l}\text { Industrial } \\
\text { Consumed }\end{array}$ & \begin{tabular}{|l|} 
F. Housing \\
Consumed
\end{tabular} & $\begin{array}{c}\text { MSE } \\
\text { Consumed }\end{array}$ & $\begin{array}{c}\text { Total } \\
\text { Consumed }\end{array}$ \\
\hline \multirow[t]{14}{*}{ ELC } & 2008 & Oct-07 & 86,521 & 0 & 0 & 7,332 & 93,854 \\
\hline & & Nov-07 & 76,064 & 0 & 0 & 7,315 & 83,379 \\
\hline & & Dec-07 & 78,616 & 0 & 0 & 6,937 & 85,552 \\
\hline & & Jan-08 & 81,612 & 0 & 0 & 0 & 81,612 \\
\hline & & Feb-08 & 75,937 & 0 & 0 & 0 & 75,937 \\
\hline & & Mar-08 & 88,395 & 0 & 0 & 0 & 88,395 \\
\hline & & Apr-08 & 86,542 & 0 & 0 & 0 & 86,542 \\
\hline & & May-08 & 102,831 & 0 & 0 & 0 & 102,831 \\
\hline & & Jun-08 & 117,380 & 0 & 0 & 0 & 117,380 \\
\hline & & Jul-08 & 118,676 & 0 & 0 & 0 & 118,676 \\
\hline & & Aug-08 & 116,636 & 0 & 0 & 0 & 116,636 \\
\hline & & Sep-08 & 85,372 & 0 & 0 & 0 & 85,372 \\
\hline & & & - & - & -- & - & -ב_- \\
\hline & & Total & $1,114,581$ & 0 & 0 & 21,584 & $1,136,165$ \\
\hline \multirow[t]{14}{*}{ NAG } & 2008 & Oct-07 & 39,959 & 0 & 0 & 528 & 40,487 \\
\hline & & Nov-07 & 83,125 & 0 & 0 & 752 & 83,877 \\
\hline & & Dec-07 & 153,324 & 0 & 0 & 973 & 154,297 \\
\hline & & Jan-08 & 201,858 & 0 & 0 & 0 & 201,858 \\
\hline & & Feb-08 & 118,993 & 0 & 0 & 0 & 118,993 \\
\hline & & Mar-08 & 111,493 & 0 & 0 & 0 & 111,493 \\
\hline & & Apr-08 & 53,911 & 0 & 0 & 0 & 53,911 \\
\hline & & May-08 & 35,083 & 0 & 0 & 0 & 35,083 \\
\hline & & Jun-08 & 25,493 & 0 & 0 & 0 & 25,493 \\
\hline & & Jul-08 & 21,812 & 0 & 0 & 0 & 21,812 \\
\hline & & Aug-08 & 20,799 & 0 & 0 & 0 & 20,799 \\
\hline & & Sep-08 & 23,884 & 0 & 0 & 0 & 23,884 \\
\hline & & & - & - & |--_-_- & - & 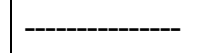 \\
\hline & & Total & 889,735 & 0 & 0 & 2,253 & 891,988 \\
\hline
\end{tabular}


Electrical energy purchased from the distribution grid in the United States will include different mixtures of renewable and non-renewable energy. One way to account for this is through the U.S. Environmental Protection Agency's (USEPA) Emissions \& Generation Resource Integrated Database (eGRID) that contains unique $\mathrm{CO}_{2}, \mathrm{CH}_{4}$, and $\mathrm{N}_{2} \mathrm{O}$ emission factors for 26 different geographic subregions in the United States. Figure 1 shows the eGRID subregions on a US map. The emission factors shown relate mass of greenhouse gas (GHG) emissions to purchased electrical energy and are based on the mixture of renewable and non-renewable electrical energy generation within the subregions. The eGRID subregions can be determined by zip code and the eGRID subregion for Fort Hood is ERCT. Information for ERCT obtained from the eGRIDWeb application ${ }^{16}$ indicates that $86.5421 \%$ of the electrical energy generation is from fossil fuel combustion. If this percentage is applied to the AEWRS electrical energy consumption of 1,136,165 MMBTU (Table 2), then 980,000 MMBTU of electrical energy consumption at Fort Hood is attributable to fossil fuel combustion.

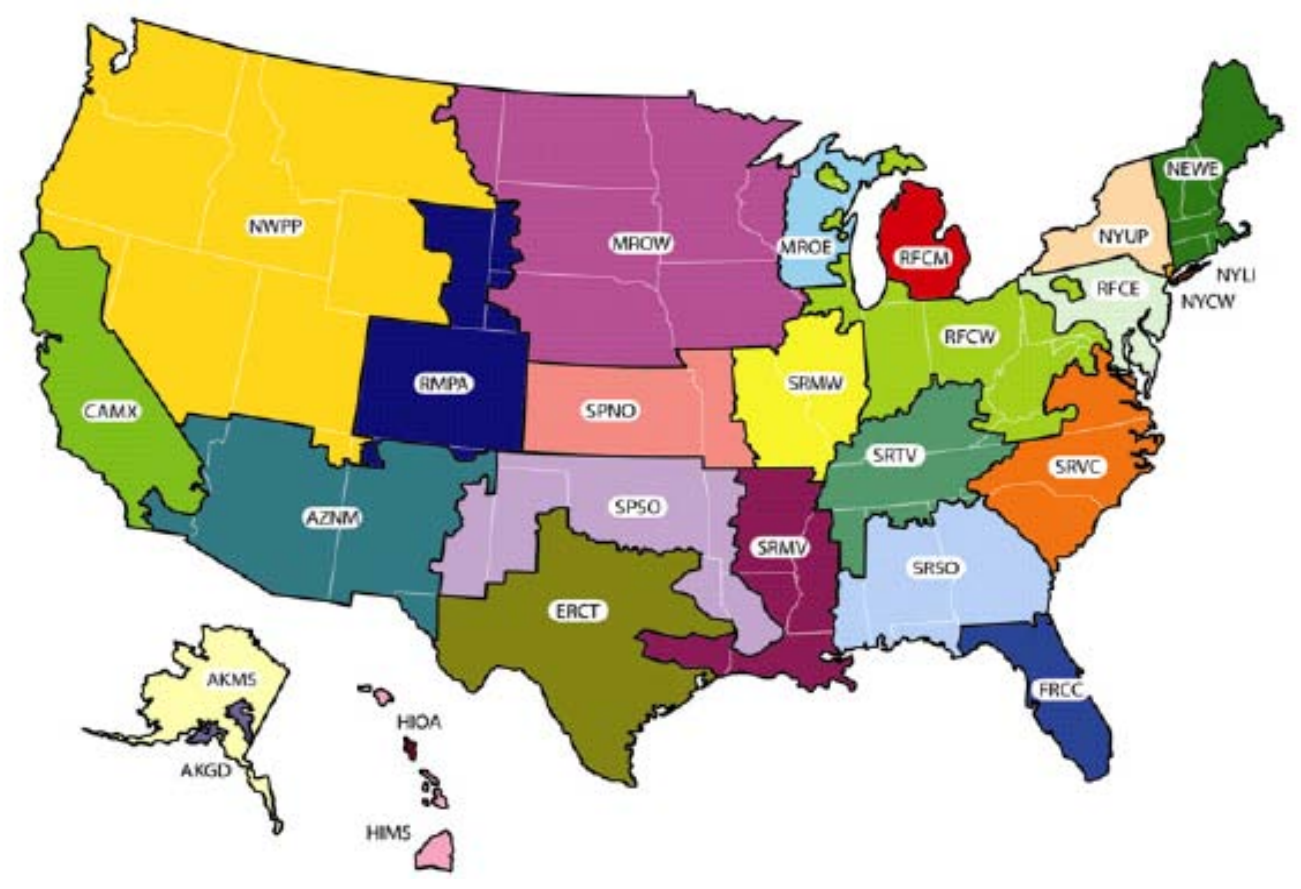

Figure 1. USEPA eGRID subregions. ${ }^{17}$

16 See http://www.epa.gov/cleanenergy/energy-resources/egrid/index.html

17 Image from USEPA Clean Energy eGRID website http://www.epa.gov/cleanenergy/documents/egridzips/eGRID2007_eGRID_subregions.jpg 


\subsubsection{Army civilian fleet vehicle fuel consumption}

As mentioned in Chapter 3, federal fleet fuel consumption information can be obtained from the GSA's FAST. FAST provides fuel consumption and fuel type data for each fleet vehicle. For Fort Hood, we obtained FY08 GSA FAST fleet data from the Directorate of Logistics Transportation motor pool and the Directorate of Public Works, which are the main two fleet vehicle organizations on the installation. Each fuel consumption record was converted to MMBTU and summed for the installation. This results in total energy consumption of 105,000 MMBTU by non-tactical fleet vehicles at Fort Hood during FY08.

\subsubsection{Army tactical vehicle fuel consumption}

As also explained in Chapter 3, tactical vehicle fuel consumption information can be obtained from OSMIS. OSMIS can generate reports that provide total fuel costs and fuel price information for tactical vehicles and weapon systems that fall into commodity groups. The commodity groups are Aviation, Combat, Electronic, Missile, Engineering, Armament, Medical, Tactical Vehicles, and Wheeled Combat. To generate the fuel consumption information for an installation, a report must be generated for each fuel type used by each commodity group. These reports are exported into spreadsheets through the OSMIS export feature. Each report will include a record for each of the weapon system and tactical vehicle types found on an installation. Fuel consumption information is calculated by dividing the total fuel cost for each weapon system by the price of the fuel. The fuel consumption must then be converted to MMBTUs. This is illustrated in Table 3, which contains a few of the records and a subset of columns from the Aviation Commodity Group report.

Summing the fuel consumption across all weapon systems in all commodity groups for Fort Hood for FY08 yielded a grand total of 4,807,000 MMBTU of energy consumed by tactical vehicles. 
Table 3. Fuel consumption calculation example information from the OSMIS Aviation Commodity Group for Fort Hood during FY08.

\begin{tabular}{|l|l|l|r|r|r|r|r|}
\hline \multicolumn{1}{|c|}{ MDS } & \multicolumn{1}{|c|}{$\begin{array}{c}\text { MDS } \\
\text { NAME }\end{array}$} & $\begin{array}{l}\text { Fuel } \\
\text { Type }\end{array}$ & $\begin{array}{c}\text { Fuel } \\
\text { Price } \\
\text { (\$/gallon) }\end{array}$ & $\begin{array}{c}\text { Total Pol } \\
\text { Cost }(\$)\end{array}$ & Gallons & $\begin{array}{c}\text { Energy } \\
\text { Conversion } \\
\text { (MMBTU/gal) }\end{array}$ & MMBTU \\
\hline UH-60A & BLACKHAWK & JP4 & 2.24 & $219,409.34$ & 97950.6 & 0.127 & 12439.726 \\
\hline UH-1H & HUEY & JP4 & 2.24 & $7,539.84$ & 3366 & 0.127 & 427.482 \\
\hline UH-6OL & BLACKHAWK & JP4 & 2.24 & $2,215,707.65$ & 989155.2 & 0.127 & 125622.71 \\
\hline CH-47D & CHINOOK & JP4 & 2.24 & $1,454,435.14$ & 649301.4 & 0.127 & 82461.278 \\
\hline AH-64D & APACHE & JP4 & 2.24 & $2,864,845.28$ & 1278948.8 & 0.127 & 162426.5 \\
\hline UH-6OA & BLACKHAWK & JP4 & 2.24 & $72,885.12$ & 32538 & 0.127 & 4132.326 \\
\hline UH-1H & HUEY & JP4 & 2.24 & $9,767.52$ & 4360.5 & 0.127 & 553.7835 \\
\hline UH-6OL & BLACKHAWK & JP4 & 2.24 & $1,156,611.46$ & 516344.4 & 0.127 & 65575.739 \\
\hline CH-47D & CHINOOK & JP4 & 2.24 & $1,149,825.60$ & 513315 & 0.127 & 65191.005 \\
\hline
\end{tabular}

\subsubsection{Energy indicator calculation}

Table 4 shows all reported energy consumed at Fort Hood from fossil fuel combustion during FY08. Tactical vehicle energy consumption dominated at Fort Hood, which is likely related to the installation's large training mission. ASIP records show that Fort Hood contained a total population of 70,812 (53,758 military and 17,054 civilian) in FY08. The calculated FY08 energy indicator for Fort Hood is therefore 6,784,000 MMBTU divided by 70,812 people or 95.4 MMBTU/ person.

Table 4. Energy consumption from fossil fuel use at Fort Hood during FY08.

\begin{tabular}{|l|l|}
\hline \multicolumn{1}{|c|}{ Energy Category } & \multicolumn{1}{|c|}{$\begin{array}{c}\text { Energy Consumption } \\
\text { from Fossil Fuel Use } \\
\text { (MMBTU) }\end{array}$} \\
\hline $\begin{array}{l}\text { Utility Fuel Combus- } \\
\text { tion }\end{array}$ & 892,000 \\
\hline $\begin{array}{l}\text { Utility Electrical } \\
\text { Energy }\end{array}$ & 980,000 \\
\hline $\begin{array}{l}\text { Civilian Fleet Ve- } \\
\text { hicles }\end{array}$ & 105,000 \\
\hline Tactical Vehicle & $4,807,000$ \\
\hline Total & $6,784,000$ \\
\hline
\end{tabular}

The value of this indicator is not meaningful except when used in comparison to previous values, and/ or in comparison to other installations. As the value of the indicator increases, the energy sustainability of the installation 
decreases. As the value of the indicator decreases, energy sustainability improves.

\subsection{Waste indicator}

\subsubsection{Hazardous waste}

Hazardous waste data can be obtained from a Defense Logistics Agency (DLA) Disposition Services ${ }^{18}$ database tool called the Environmental Reporting System (ERS). ERS is the data warehouse ${ }^{19}$ for the Base Operations Supply System (BOSS) that manages Hazardous Contracting, Finance, and Manifest Tracking data for all Defense Reutilization Marketing Offices (DRMOs).

ERS data come from two main areas of BOSS - the Hazardous Line Item and the Manifest Line Item. Data are extracted by DLA on a daily basis from BOSS and updated in ERS. Data are stored in an ORACLE database and DISCOVERER VIEWER formatted reports are set up to run against the database. Once the report has been run, users have the option of exporting data to make it available for use in reports, charts, or for loading into another database.

The DISCOVERER VIEWER opening page presents a list of reports that have been developed for BOSS data. The Generator DoDAAC/ HIN, Pickup DoDAAC Summary report provides information on the weight of hazardous waste disposed and the cost associated with the disposal. The report can be queried by a range of delivery order issue dates, the DRMO contract number, and the installation's Generator Department of Defense Activity Address Code (DoDAAC). The Generator DoDAAC/ HIN, Pickup DoDAAC Summary report generates a list of all the Generator DODAACs related to the query parameters.

Table 5 shows the column headings and their association with BOSS data.

\footnotetext{
18 DLA Disposition Services disposes of excess property received from military services. For more information, see www.drms.dla.mil .

19 Information about ERS can be found at: http://www.drms.dla.mil/newenv/hazardousreports.shtml.
} 
Table 5. AE - Generator DoDAAC/HIN, Pickup DoDAAC Summary Report column descriptions.

\begin{tabular}{|l|l|}
\hline \multicolumn{1}{|c|}{ Column Label } & \multicolumn{1}{c|}{ Associated Field } \\
\hline Generator DODAAC & Generator DoD Activity Address Code \\
\hline Pickup DoDAAC & Pickup DoD Activity Address Code \\
\hline Pickup Name & $\begin{array}{l}\text { Name associated with the Pickup Do- } \\
\text { DAAC }\end{array}$ \\
\hline HIN & Hazardous item number \\
\hline Description & HIN description \\
\hline Quantity & Sum of obligated quantity for the HIN \\
\hline UM & Unit of measure for the HIN \\
\hline COST & Sum of all obligated costs for the HIN \\
\hline
\end{tabular}

To create a report for a specific installation, the Generator DoDAAC/ HIN, Pickup DoDAAC Summary report can be queried by providing the installation's Generator DoDAAC and a range of dates. For example, Table 6 shows the report results for FY09 at Fort Lewis. The report shows the quantity and costs for each of the HINs during FY09. The HINs include disposal costs for hazardous waste categories, hazardous waste equipment costs, and hazardous waste service costs. In this example the hazardous waste cost component of the waste indicator would be $\$ 695,055$.

Table 6. Generator DoDAAC/HIN, Pickup DoDAAC Summary Report for FY09 at Fort Lewis.

\begin{tabular}{|c|l|r|l|r|}
\hline HIN & \multicolumn{1}{|c|}{ Description } & Quantity & UM & \multicolumn{1}{c|}{ Cost } \\
\hline 0812 AB & Small cylinder, engine start cartridges & 23 & EA & $\$ 1,723$ \\
\hline 087200 & Cylinder- small & 7 & EA & $\$ 831$ \\
\hline 632100 & $\begin{array}{l}\text { Provide and prepare lab packs, consist- } \\
\text { ing of small quantity items (55 gal) }\end{array}$ & 132 & EA & $\$ 29,615$ \\
\hline 632300 & $\begin{array}{l}\text { Provide and prepare lab packs, consist- } \\
\text { ing of small quantity items (5-15 gal) }\end{array}$ & 4 & EA & $\$ 542$ \\
\hline 633200 & Expedited removal - 7 Days & 1 & EA & $\$ 283$ \\
\hline 633400 & Expedited removal - 3 Days & 2 & EA & $\$ 1,153$ \\
\hline 635000 & $\begin{array}{l}\text { Tank cleaning/services - (above ground) } \\
\text { mobilization cost }\end{array}$ & 3 & EA & $\$ 5,617$ \\
\hline 635600 & $\begin{array}{l}\text { Tank cleaning/services - additional mo- } \\
\text { bilization cost for confined entry }\end{array}$ & 3 & EA & $\$ 605$ \\
\hline
\end{tabular}




\begin{tabular}{|c|c|c|c|c|}
\hline HIN & Description & Quantity & UM & Cost \\
\hline 636000 & $\begin{array}{l}\text { Personnel for cleaning/servicing of } \\
\text { tanks, totes, oil/water separators (team } \\
\text { leader) }\end{array}$ & 16 & EA & $\$ 1,197$ \\
\hline 636100 & $\begin{array}{l}\text { Personnel for cleaning/servicing of } \\
\text { tanks, totes, oil/water separators } \\
\text { (technician) }\end{array}$ & 24 & EA & $\$ 1,133$ \\
\hline 637200 & Provide storage container (20 Cyl) & 2 & EA & $\$ 1,844$ \\
\hline 637500 & Provide storage container (40 Cyl) & 4 & EA & $\$ 3,804$ \\
\hline 638500 & Rental - storage containers (40 Cyl) & 1 & EA & $\$ 483$ \\
\hline $6400 A B$ & Prepare Waste Profile form & 31 & EA & $\$ 3,573$ \\
\hline 6400TS & $\begin{array}{l}\text { Perform unknown analysis (two-step) } \\
\text { and prepare waste profile form. }\end{array}$ & 1 & EA & $\$ 732$ \\
\hline 641800 & $\begin{array}{l}\text { Provide incineration and stabilization of } \\
\text { lab packs, non-lab packed waste, non- } \\
\text { regulated waste, and soil samples (in } \\
\text { accordance with } 40 \text { CFR } 268 \text { Appendix } \\
\text { IV and for solid wastes not subject to } \\
\text { regulations under } 40 \text { CFR 261). }\end{array}$ & 21,260 & EA & $\$ 12,300$ \\
\hline $6500 \mathrm{MM}$ & $\begin{array}{l}\text { Surcharge for disposal of high level } \\
\text { mercury }\end{array}$ & 315 & LB & $\$ 1,571$ \\
\hline 650200 & Perform management services & 24 & $\mathrm{HR}$ & $\$ 1,492$ \\
\hline 6502ZD & Management services & 357 & EA & $\$ 20,467$ \\
\hline 701400 & Small capacitors 500-4999 ppm Pcb & 66 & LB & $\$ 97$ \\
\hline $7014 A A$ & $\begin{array}{l}\begin{array}{l}\text { Small capacitors } 500 \text { ppm \& over Pcb } \\
\text { (w/ballasts) }\end{array} \\
\end{array}$ & 643 & LB & $\$ 582$ \\
\hline 702800 & $\begin{array}{l}\text { Debris (example: rags, cans, drums, } \\
\text { wood) Pcb contaminated }\end{array}$ & 77 & LB & $\$ 42$ \\
\hline 910100 & Ignitable - small containers & 6,849 & LB & $\$ 4,035$ \\
\hline 910200 & $\begin{array}{l}\text { Ignitable - containerized liquids/multi- } \\
\text { phase }\end{array}$ & 31,360 & LB & $\$ 11,547$ \\
\hline 9102RR & $\begin{array}{l}\text { Ignitable - containerized liquids/multi- } \\
\text { phase - mandatory recycling/fuels } \\
\text { blending }\end{array}$ & 12,952 & LB & $\$ 4,137$ \\
\hline 910400 & Ignitable - containerized solids & 17,966 & LB & $\$ 13,958$ \\
\hline 910600 & Ignitable - bulk liquids (pumpable) & 160,040 & LB & $\$ 55,795$ \\
\hline 9106RR & $\begin{array}{l}\text { Ignitable - bulk liquids (pumpable) -- } \\
\text { mandatory recycling }\end{array}$ & 44,435 & LB & $\$ 12,442$ \\
\hline 9108CD & CDE Kits - liquid and/or solid & 751 & LB & $\$ 1,187$ \\
\hline 920100 & Corrosive - small containers & 1,514 & LB & $\$ 785$ \\
\hline
\end{tabular}




\begin{tabular}{|c|c|c|c|c|}
\hline HIN & Description & Quantity & UM & Cost \\
\hline 920200 & $\begin{array}{l}\text { Corrosive - containerized liquids/multi- } \\
\text { phase }\end{array}$ & 7,653 & LB & $\$ 2,907$ \\
\hline 920400 & Corrosive - containerized solids & 31 & LB & $\$ 15$ \\
\hline 9204LA & Corrosive - containerized solids & 64 & LB & $\$ 20$ \\
\hline 9204NC & Corrosive - containerized solids & 1,186 & LB & $\$ 969$ \\
\hline 9204NH & Containerized solids & 1,117 & LB & $\$ 916$ \\
\hline 920600 & Corrosive - bulk liquids (pumpable) & 3,790 & LB & $\$ 1,251$ \\
\hline 9208CD & CDE Kits liquid and/or solid & 63 & LB & $\$ 106$ \\
\hline 930100 & Reactive - small containers & 729 & LB & $\$ 1,092$ \\
\hline 930400 & Reactive - containerized solids & 351 & LB & $\$ 608$ \\
\hline 9304LL & Reactive - containerized solids & 16,926 & LB & $\$ 38,023$ \\
\hline 930500 & Reactive - aerosols & 21,782 & LB & $\$ 20,160$ \\
\hline $9308 \mathrm{CD}$ & CDE Kits - liquid and/or solid & 10 & LB & $\$ 35$ \\
\hline 940100 & Toxicity - small containers & 798 & LB & $\$ 462$ \\
\hline 9401MM & $\begin{array}{l}\text { Toxicity - small containers with mer- } \\
\text { cury/mercury compounds }\end{array}$ & 691 & LB & $\$ 3,752$ \\
\hline 940200 & $\begin{array}{l}\text { Toxicity - containerized liquids/multi- } \\
\text { phase }\end{array}$ & 21,009 & LB & $\$ 7,749$ \\
\hline 940400 & Toxicity - containerized solids & 14,910 & LB & $\$ 5,751$ \\
\hline 9404FT & $\begin{array}{l}\text { Toxicity - containerized solids fluores- } \\
\text { cent tubes }\end{array}$ & 16,366 & LB & $\$ 15,150$ \\
\hline 9404MB & Toxicity - containerized solids & 6 & LB & $\$ 23$ \\
\hline 9404MG & Toxicity - containerized solids & 32 & LB & $\$ 42$ \\
\hline 9404NC & Toxicity - containerized solids & 6,674 & LB & $\$ 5,531$ \\
\hline 940700 & Toxicity - bulk solids & 7,840 & LB & $\$ 2,744$ \\
\hline 9407DB & Toxicity - bulk solids & 794 & LB & $\$ 667$ \\
\hline 9407PL & $\begin{array}{l}\text { Bulk solids packed in large (>119 gal) } \\
\text { boxes by generator }\end{array}$ & 1,090 & LB & $\$ 545$ \\
\hline 9408CD & CDE Kits liquid and/or solid & 3,293 & LB & $\$ 5,455$ \\
\hline 950100 & Solvent - small containers & 586 & LB & $\$ 305$ \\
\hline 950200 & $\begin{array}{l}\text { Solvent - containerized liquids/multi- } \\
\text { phase }\end{array}$ & 9,850 & LB & $\$ 3,422$ \\
\hline 950400 & Solvent - containerized solids & 4,259 & LB & $\$ 3,186$ \\
\hline 970100 & P-Listed - small containers & 22,776 & LB & $\$ 37,261$ \\
\hline 9708CD & CDE Kits liquid and/or solid & 4 & LB & $\$ 7$ \\
\hline 975100 & U-Listed - small containers & 421 & LB & $\$ 280$ \\
\hline
\end{tabular}




\begin{tabular}{|c|c|c|c|c|}
\hline HIN & Description & Quantity & UM & Cost \\
\hline 975200 & $\begin{array}{l}\text { U-Listed - containerized liquids/multi- } \\
\text { phase }\end{array}$ & 153 & LB & $\$ 65$ \\
\hline 975400 & U-Listed - containerized solids & 376 & LB & $\$ 355$ \\
\hline 980100 & State Reg - small containers & 11,641 & LB & $\$ 5,000$ \\
\hline 980200 & $\begin{array}{l}\text { State Reg - containerized liquids/multi- } \\
\text { phase }\end{array}$ & 99,708 & LB & $\$ 33,711$ \\
\hline 980400 & State Reg - containerized solids & 87,246 & LB & $\$ 80,861$ \\
\hline 980600 & State Reg - bulk liquids (pumpable) & 283,885 & LB & $\$ 65,294$ \\
\hline 980700 & State Reg - bulk solids & 55,190 & LB & $\$ 25,387$ \\
\hline $9808 \mathrm{CD}$ & CDE Kits liquid and/or solid & 253 & LB & $\$ 418$ \\
\hline 990100 & Non Reg - small containers & 16,764 & LB & $\$ 6,357$ \\
\hline 990200 & $\begin{array}{l}\text { Non-Reg - containerized liquids/multi- } \\
\text { phase }\end{array}$ & 35,364 & LB & $\$ 10,382$ \\
\hline 9902AF & $\begin{array}{l}\text { Non-Reg - containerized liquids/multi- } \\
\text { phase }\end{array}$ & 4,943 & LB & $\$ 1,675$ \\
\hline 9902FA & $\begin{array}{l}\text { Non-Reg - containerized liquids/multi- } \\
\text { phase }\end{array}$ & 35,669 & LB & $\$ 10,990$ \\
\hline 9902RR & $\begin{array}{l}\text { Containerized liquids/multi-phase, fuels } \\
\text { blending }\end{array}$ & 9,730 & LB & $\$ 2,822$ \\
\hline 990400 & Non-Reg - containerized solids & 142,100 & LB & $\$ 46,586$ \\
\hline 9904AB & Non-Reg - containerized solids & 8,525 & LB & $\$ 6,698$ \\
\hline 9904CZ & Non-Reg - containerized solids & 347 & LB & $\$ 273$ \\
\hline 9904LA & Record created by rehost conversion & 276 & LB & $\$ 88$ \\
\hline 990500 & Non-Reg - aerosols & 122 & LB & $\$ 113$ \\
\hline 990600 & Non-Reg bulk liquids (pumpable) & 18,320 & LB & $\$ 4,030$ \\
\hline 990700 & Non-Reg - Bulk Solids & 121,060 & LB & $\$ 29,054$ \\
\hline 9907PL & Non-Reg - Bulk Solids & 13,867 & LB & $\$ 3,328$ \\
\hline \multirow[t]{2}{*}{ 9908CD } & CDE Kits Liquid and/or Solid & 5,701 & LB & $\$ 9,566$ \\
\hline & Sub-Total: & $1,415,204$ & & $\$ 695,055$ \\
\hline
\end{tabular}

\subsubsection{Non-hazardous waste}

For nonhazardous waste, data can be obtained from the Solid Waste Annual Reporting (SWAR) system. The SWARWeb system is a data management system designed to facilitate tracking and reporting of solid waste and recycling data at $\mathrm{DoD}$ facilities. Army installations are required to report their nonhazardous solid waste generation and cost information using this system. 
SWARWeb is located on the Army Knowledge Online (AKO) Installation Management Applications Resource Center (IMARC) page. ${ }^{20}$ SWARWeb is a web-based program, allowing access via User ID and password from any Internet-connected computer. The IMARC portal contains other Assistant Chief of Staff for Installation Management (ACSIM) systems. ${ }^{21}$

Cost and revenue information about Army installations' non-hazardous solid waste management program can be extracted from the Comprehensive Report that SWARWeb provides. The report is based on an installation's data input for solid waste disposal and diversion. The information tracks both costs for disposal and treatment along with any revenue from the installation's recycling programs. Section 8 of the report summarizes solid waste management information. Figure 2 shows this section for Fort Lewis's FY09 information. The bottom of the report contains a cost figure labeled ADC that is used in calculating cost avoidance information. The $\mathrm{ADC}$ cost reflects all non-hazardous waste disposal costs, program costs, and revenues/ costs from the recycling program. In the case of Fort Lewis in FY09 this cost was $\$ 1,730,337.76$.

\footnotetext{
${ }^{20}$ Accessible to registered users at https://imcom-it.apgea.army.mil/imarc/web/access/login
}

21 https://www.us.army.mil/suite/page/550262 
Comprehensive Report

WA215220506 - FORT LEWIS

FY2009 (From 10/01/2008 to 09/30/2009)

SECTION 8. INSTALLATION INTEGRATED SOLD WASTE MANAGEMENT SUMMARY

DOD MOM:

Overall Diversion Rate: $77.47 \%$

Integrated SW Management Cost Avoidance(\$): 1, 971, 729.96

Breakout of other Totals and Diversion rates:

Generation

(US)

Total

$C \& D$

Non $C \& D$

WCF

Non WCF

Without C\&D and WCF

Without Composting

Without $C \& D$ and Composting

QRP

Non-QRP

Daily Per Capita

MSW (lbs/person/day)

(Cost)/Revenue Summary:

C\&D

WCF

Without C\&D and WCF

QRP

Non-QRP

DRMO

Daily Per Capita

(\$/person/day)

Breakout of Cost Avoidance:

Total
PDC

(\$)

$59,180.9998$

$10,749.5065$

$48,431.4933$

0.0000

$59,180.9998$

$48,431.4933$

$59,180.9998$

$48,431.4933$

Generation

(\$)

$(220.64)$

0.00

$(1,730,117.12)$

(0.09)

$, 702,067.72$
Disposal

(US)

$13,331.2368$

18.6800

$13,312.5568$

0.0000

$13,331.2368$

$13,312.5568$

$13,331.2368$

$13,312.5568$

$45,849.7630$

$35,118.9365$

0.0000

$36,541.7915$

1.4305

3.7738
Diversion

$(220.64)$

0.00

0.00

$(166,314.35)$

0.00

$(77,013.67)$

$(89,521.32)$

$(0.01)$

Figure 2. Section 8 of Fort Lewis's SWARWeb comprehensive report for FY09. 


\subsubsection{Waste indicator}

The waste indicator is the sum of hazardous waste costs and nonhazardous solid waste costs divided by the installation population. For Fort Lewis in FY09, the hazardous waste costs were \$695,055 and the non-hazardous waste costs were $\$ 1,730,338$ (total $\$ 2,425,393$ ). ASIP shows that the Fort Lewis total population for FY09 was 44,239 (34,036 military and 10,203 civilian personnel). The FY09 waste indicator for Fort Lewis was therefore $\$ 2,425,393$ divided by 44,239 people or $\$ 54.82$ per person.

As with energy, the value of this indicator is not meaningful except for comparisons to previous values and to other installations. Obviously, the sustainability goal would be to minimize the installation's cost per person to dispose of waste.

\subsection{Land indicator}

The land indicator is defined as a ratio of the amount of land needed to accomplish maneuver training to the total amount of land that is available. Land use is measured in acre-days (e.g., one acre of land used for training one day equals one acre-day). If 10 acres were used all year, the land use calculation would be 10 acres $\times 365$ days $=3,650$ acre-days. The total acredays of training land available is reported on ISR-NI sheet MS101-2 in the column titled "Available Acre-Days Remaining" (although it would seem that this column should be titled "Available Acre-Days"). This entry takes into consideration days when maneuver areas are not available. MS101-2 shows entries for "Heavy Maneuver" and "Light Maneuver." Normally, all acres available for heavy maneuver training also are available for light maneuver training. Therefore, the "Available Acre-Days Remaining for Light Maneuver" entry is used as the value for the total acre-days available for maneuver training at an installation.

The number of acre-days required by each Army Unit using maneuver training land at an installation is reported in ISR-NI sheet MS101-3 "Training Acre-Day Requirements." Then, the total acre-days needed for maneuver training is the sum of all entries in the "Training Acre-Day Requirements" column. The value of the land indicator is then the sum of the entries for "Training Acre-Day Requirements" divided by the "Available Acres-Days Remaining for Light Maneuver." 
Table 7 shows a hypothetical example for the fictional "Camp Swampy." At Camp Swampy, there are four heavy maneuver units of varying types and training requirements. Camp Swampy has a total of 25,000,000 training acre-days available during a calendar year after all restrictions on training land use have been accounted for.

Table 7. Example hypothetical training schedule.

\begin{tabular}{|l|l|c|c|}
\hline \multicolumn{1}{|c|}{ Training Type } & \multicolumn{1}{|c|}{ Unit } & $\begin{array}{c}\text { Training Acre-Day } \\
\text { Requirement }\end{array}$ & $\begin{array}{c}\text { Available Acre-Days } \\
\text { Remaining }\end{array}$ \\
\hline Heavy Maneuver & 01231 & $4,500,000$ & $20,500,000$ \\
\hline Heavy Maneuver & 01232 & $6,000,000$ & $14,500,000$ \\
\hline Heavy Maneuver & 01233 & $1,500,000$ & $13,000,000$ \\
\hline Heavy Maneuver & 01234 & $5,000,000$ & $8,000,000$ \\
\hline & Total Required & $17,000,000$ & \\
\hline
\end{tabular}

The land indicator is reported as a percentage. In this simplistic example, $17,000,000$ acre-days of annual training capacity are needed of the $35,000,000$ acre-days available. Thus the land indicator for Camp Swampy would have a value of $17,000,000 / 25,000,000$, or $68 \%$. When the value is less than $100 \%$, the installation has enough maneuver area available. If the value is more than $100 \%$, there is not enough maneuver area available at the installation.

NOTE: There seems to be a problem with ISR-NI sheet MS 101 report design. The apparent purpose of ISR-NI sheet MS101-3 is to determine whether there is enough land available for maneuver training. However, it appears that this sheet is designed incorrectly; it calculates whether there is land capacity for each individual unit, but not does not calculate whether there is land capacity to satisfy the land requirements for all of the units combined. Furthermore, some of the data entered into the system seems to be incorrect (for example, at Fort Carson all of the units report doing maneuver training 365 days a year). It is recommended that HQ IMCOM correct the calculation function used to report the status of Maneuver Land Capacity. IMCOM should consider a general quality assessment of ISR-NI regarding how data elements are defined and reported.

\subsection{Economic impact indicator}

The indicator for economic impact is defined as the ratio of the total personal income for the military and civilian personnel at an installation ver- 
sus the gross domestic product (GDP) for the regional Metropolitan Statistical Area (MSA) that includes the installation. The GDP for the regional MSAs is readily available for many of the IMCOM installations through the Bureau of Economic Analysis (BEA) website. ${ }^{22}$ The difficulty with using the MSA data from BEA is that the most recent data may be for statistics two years previous to the date of the search; thus, data for this indicator may lag behind data for the other sustainability indicators.

Table 8 shows installations found within the borders of regional and micro MSAs. (Our search of BEA statistics has not yet located a good representation of regional GDP outside MSAs.)

Installations often use figures from the personal income of military and civilian personnel (payroll) for various purposes. That data is undoubtedly available to IMCOM from the Human Resources groups within the Directorate of Resource Management (DRM) at both the installation and headquarters (HQ) IMCOM level.

As the value of the economic indicator increases, the relative impact the installation has on the local economy increases.

Table 8. Army installations with the borders of regional and micro MSAs.

\begin{tabular}{|l|l|}
\hline MSA & Installation \\
\hline Alexandria (Polk), LA & Fort Polk \\
\hline Las Cruces or Alamogordo, NM & White Sands Missile Range \\
\hline Baltimore, MD & Aberdeen Proving Grounds \\
\hline Clarksville, TN & Fort Campbell \\
\hline Colorado Springs, CO & Fort Carson \\
\hline Dothan, AL & Fort Rucker \\
\hline El Paso, TX & Fort Bliss \\
\hline Fayetteville, NC & Fort Bragg \\
\hline Harrisburg, PA & Fort Indiantown Gap \\
\hline Hinesville, GA & Fort Stewart \\
\hline
\end{tabular}

22 The Bureau of Economic Analysis website is available at www.bea.gov/regional/bearfacts. 


\begin{tabular}{|l|l|}
\hline MSA & Installation \\
\hline Honolulu, HI & $\begin{array}{l}\text { Schofield Barracks; } \\
\text { Fort Shafter }\end{array}$ \\
\hline Killeen, TX & Fort Hood \\
\hline Olympia, WA & Fort Lewis \\
\hline Richmond, VA & Fort Lee; Fort A.P. Hill \\
\hline San Antonio), TX & Fort Sam Houston \\
\hline Tucson, AZ & Fort Huachuca \\
\hline Washington, DC & Numerous installations \\
\hline Watertown, NY & Fort Drum \\
\hline Yuma, AZ & Yuma Proving Grounds \\
\hline
\end{tabular}

\subsection{Well-being indicator}

The Army cannot exist without its soldiers and civilians, and thus its sustainability depends on their well-being. As can be seen in the well-being section of Chapter 3, aspects such as well-being or quality of life are intangible and thus difficult to measure and quantify, especially compared to other sustainability elements like water, land, or energy. It has been difficult, therefore, to find installation-level indicators to represent this essential component of Army sustainability. The recommendation is to look to a relatively new effort at the Well-Being Division of the Army Office of the Deputy Chief of Staff, G-1, Human Resources Policy Directorate (HRPD). On their public website, 23 they describe themselves on the "About Us" page:

${ }^{23} \mathrm{http}: / /$ www.armywell-being.org (last accessed 20 August 2010) They also have a website at http://www.armyg1.army.mil/hr/wellBeing.asp (last accessed 17 September 2010). 
The Army Well Being Division provides a central source of compiled human dimension data (both objective and subjective) with the commensurate analytical capability to inform Human Capital Strategy, policy and program decisions and to provide assessments of issues related to the well-being of the force. In short, we are a key measurement tool for senior Army leadership.

We provide the capability to use metric analyses and assessments to inform Strategy, policy, Core Enterprise Activities, Task Force operations and Army Staff Action Plans.

We provide knowledgeable and trained Subject Matter Experts in support of G-1/ HRPD Human Capital Strategy, Human Dimension, Well-Being of the Force and Health of the Force requirements for information, recommendations and assessments.

It is clear that the Army Well-Being Division is a compelling potential source for an installation-level sustainability indicator for well-being. The Division is initiating the development of a well-being dashboard that is organized around five domains of well-being: ${ }^{24}$

1. standard of living

2. career

3. health

4. personal life

5. community

The Division's current efforts at quantifying well-being have two main dashboards: "Soldier, Civilian, and Family Indicators" and "Violent Crimes." Both include a number of subtopics populated from many internal Army sources that provide a spectrum of metrics and indicators.

Our recommendation for an installation-level sustainability indicator for well-being is that IMCOM coordinate efforts with the Well-Being Division. They clearly have both a mission and a strategy that align well to serve the purposes of the well-being indicator. However, they are only in the beginning stages of standing up their dashboards. Currently their dashboard

24 The information herein has been compiled from notes from several telephone conversations with Mr. David White, Chief of the Well-Being Division HRPD, that took place July-August 2010. 
provides data and analysis at the Army-wide level, but does not yet have the ability to drill down to the installation or unit level. Also, they provide a dashboard of many indicators, not a single indicator. They do have a notional strategy to create such a single indicator, however, through the development of an algorithm and weighting scheme.

\subsection{Army Strategic Management System}

The data that support many of the installation sustainability indicators are found in ISR-NI, AEWRS, and SWAR systems. These data (and more) are expected to be available in the Army's Strategic Management System (SMS). It is therefore our hope that SMS will be the home for the installation sustainability indicators so that they can ultimately be of use not only to IMCOM and its installations, but also to the Army as a whole. 


\section{Comparison of Approaches for Capturing the Level of an Organization's Sustainability}

Our work proposes to IMCOM a set of brief, concrete measures that will give a straightforward indication of whether (and if so, how) an installation is progressing towards becoming more sustainable. That set of installation sustainability indicators must also allow a roll-up of installationlevel facts such that the parent command can understand how it, too, is progressing as a whole. In order to expose any deficiencies in our approach to designing that set of indicators, we compared our proposed indicators to other approaches that also could be potentially applicable to an Army installation context. Our intention was to establish whether other approaches addressed a topic (or topics) important enough to require us to substitute it for one or more members of our set of proposed indicators.

This chapter describes the approaches we reviewed and some advantages of each. Included is information about the relative complexity of the approach and whether its indicators are quantitative, qualitative, or simple "yes/ no" type. Appendix A reproduces the tables that instantiate the comparisons.

\subsection{Approaches reviewed}

We reviewed and agreed to look further at the following approaches to capturing an organization's relative degree of sustainability:

- The Tri-Services Sustainable Communities Scorecard 25 from The TriService Sustainable Communities, a collaboration led by the Air Force Center for Environmental Excellence (AFCEE).

- The Atkinson Group's SERDP-funded 2009 report, "Sustainability Assessment of a Military Installation: A Template for Developing a Mission Sustainability Framework, Goals, Metrics, and Reporting System." ${ }^{26}$ Authors Alan Atkinson, David Berry, and Lee Hatcher provide a

25 This evaluation was based on Version 9 (6-Nov-09) of the working draft of the Tri-Services Sustainable Communities Credit Table. The POC for the coordination of the Tri-Services Sustainable Communities group at AFCEE is Christopher Kruzel (Christopher.Kruzel@brooks.af.mil; 210 536-8951).

${ }^{26}$ Available at http://www.serdp.org/Research/upload/SustainAssessMili.pdf (accessed 22-Jan-10). 
prototype system to be used by an installation to establish sustainability metrics.

- The College Sustainability Report Card ${ }^{27}$ which is designed to collect metrics on hundreds of colleges from publically available data and surveys. The report card's design makes comparisons between colleges possible.

- Executive Order (EO) 13514, October 5, $2009^{28}$ was included in our review since it (and the implementation guidance that will ultimately followit) will shape much of the U.S. Government's future sustainabilityrelated activities. This EO represents the most comprehensive set of federal sustainability policies and goals to date. The EO is not analogous, however, to the other scorecards and metrics in this comparison, especially since it is not optional. Compliance with EO 13514 also will not answer the question, "How sustainable is IMCOM?"

- The Army Sustainability Campaign Plan (ASCP) because it also will serve as a touchstone for much of the Army's future activity.

We also considered two other approaches but decided not to include them in our comparison, as explained below:

- Installation Strategic and Sustainability Planning. The ISSP process was one of the early appearances of the concept of sustainability in the Army. It can be seen as a bottom-up approach that has created an awareness of sustainability concepts across installation communities. A review of the available ISSP documents ${ }^{29}$ did not provide a consistent set of goals or metrics that could be compiled for a comparison such as this. The ISSP template ${ }^{30}$ includes a step for establishing baseline data for the suggested groupings such as utilities, infrastructure, transportation, procurement, environmental, regional, operations and training, and military community. However, upon examination, the goals from the ISSP processes of a number of installations exhibit little or no overt connection to baselines in the goal statements or to how the goal would be tracked against trends in the data. A report prepared for the Army ${ }^{31}$

\footnotetext{
27 Available at http://www.greenreportcard.org/ (last accessed 22-Jan-10).

28 Available at http://edocket.access.gpo.gov/2009/pdf/E9-24518.pdf (last accessed 22-Jan-10).

29 Appendix B provides a summary of ISSP goals and status for 22 installations.

30 For instance, see the Installation Sustainability Planning Guide at http://www.sustainability.army.mil/tools/programtools_guide.cfm (last accessed 8-Feb-10).

31 Lachman, B., E. Pint, G. Cecchine, and K. Collaton. 2009. "Developing Headquarters Guidance for Army Installation Sustainability Plans in 2007". RAND Corporation Report available at http://www.rand.org/pubs/monographs/MG837/ (last accessed 8-Feb-10).
} 
looked at the ISSP process, initial outcomes, and provided recommendations for future improvements. In that report, Lachman et al. noted that the ISSP process has no requirements or follow-through to identify the most important, strategic, or pressing sustainability issue. ${ }^{32}$ Perhaps this may have led to what they also observed by writing, "so far most installations tend to place too much emphasis on easier sustainability approaches, such as technology adoption and issues internal to the installation, and not enough emphasis on assessing and considering regional trends, relationships, and effects that can be important for long-term installation sustainability." 33 Thus, while the ISSP process could perhaps be better informed by a set of installation sustainability indicators, that process does not provide ready examples of what those indicators might look like.

- The Global Reporting Initiative(GRI). ${ }^{34}$ The GRI sustainability performance indicators are the outcome of an international, consensusbased process that engaged a wide range of stakeholder groups in the development of a tool that would support public reporting of organization-specific information on sustainability. It represents an extensive catalog of topics connected to sustainability that was agreed upon as part of that international effort. The extent to which the GRI performance indicators are used in an organization's public reporting on its sustainability is left entirely to the discretion of the individual reporting organization. GRI's 79 performance indicators are grouped under the following headings: Economic (9), Environmental (30), and Social (40). Obviously, each of these topics embraces quite a large number of indicators (none of which is explicitly motivated); therefore, its utility in working toward a concise set of sustainability indicators is limited. GRI's indicators are not amenable to roll up, i.e., there is no way to take a subset of GRI indicators and combine them to arrive at a good summary of how sustainable an organization is. Indeed, GRI is not so much a list of indicators as a list of potential concerns that a company or consumer may have when thinking about sustainability. While it

\footnotetext{
32 Lachman, B., E. Pint, G. Cecchine, and K. Collaton. 2009. “Developing Headquarters Guidance for Army Installation Sustainability Plans in 2007". RAND Corporation Report. http://www.rand.org/pubs/monographs/MG837/ (last accessed 8-Feb-10), p. 64.

33 Ibid.

${ }^{34}$ For a detailed discussion of the GRI as it is used for Army Sustainability Reporting see Foltz, S., G. Gerdes, M. Hanson, D. Krooks, and C. Rewerts, "Public Reporting and a More Sustainable Army". Technical Report, 14 Apr 09, ERDC-CERL, Champaign, IL, Report No ERDC/CERL TR-09-11. http://www.cecer.army.mil/techreports/ERDC-CERL_TR-09-11/ERDC-CERL_TR-09-11.pdf (last accessed 7-Feb-10).
} 
may have value as a framework for public reporting, the tool's level of complexity makes it an unlikely candidate for building a set of sustainability indicators.

\subsection{Review comments}

\subsubsection{The Tri-Services Sustainable Communities Scorecard}

The Tri-Services Scorecard is focused on compliance with requirements and on giving an installation credit for its attempts to become more sustainable across a wide range of possibilities. One striking feature is its rather narrow emphasis only on keeping required plans updated. Plans are all well and good, but the measure of an organization's sustainability is going to come not from having an updated plan but from making that plan a good one and then executing it well.

The Tri-Services group is seeking to build a scorecard that will be a comprehensive, installation-based sustainability rating system using an approach similar to LEED ${ }^{\circledR}$ (Leadership in Energy and Environmental Design). Installation personnel will use the scorecard as a checklist of their accomplishments, to obtain an overall rating. The current version of the Sustainable Communities Scorecard is a rating system that uses a combination of "Requirements" and "Credits" to show compliance with federal requirements (Requirements) and to document best practices (Credits). The rating system is comprised of 10 categories: Community Design and Development; Energy and Greenhouse Gases; Water Efficiency; Built Infrastructure; Natural Infrastructure; Materials and Waste Management; Transportation; Human Health, Development, and Productivity; Community Engagement; and Innovation \& Regional. Each category is defined by the credits and requirements within it. Scoring for a category cannot begin without the requirements having been accomplished, while credits allow an installation optional ways to increase their score. There has been discussion of an added mechanism to provide the incorporation of life-cycle cost effectiveness as part of the prioritization of actions.

There are a number of benefits to the Tri-Services approach. It is relatively simple and does not mandate that installations do more than what is already required. It also streamlines the tracking of installation compliance with the requirements in a more centralized, enterprise process. Assuming that the types of optional credits can evolve to capture a wide spectrum of the equivalent of best management practices for sustainability, this ap- 
proach could prove to be as useful to installations as LEED has been to buildings. However, compliance is not necessarily equal to sustainability, and this system will not inform installations as to whether or not they are becoming more sustainable.

\subsubsection{The SERDP Atkinson Report}

The Atkinson, Inc., SERDP final report is titled "Sustainability Assessment of a Military Installation: A Template for Developing a Mission Sustainability Framework, Goals, Metrics, and Reporting System." 35 The expressed need for this SERDP report is the premise that existing sustainability metrics and management frameworks are not adequate due to the complexity of military installations. However, the report makes no argument as to why this premise is true. Nor does the report compare the sustainability management needs of the military with other metrics-based systems, such as GRI. The report does express a somewhat unique definition of installation sustainability: "Capacity for continuous operations in the long term coupled with resilience for maintaining operations in the case of shortterm shocks and disturbances." (p. 8)

The study developed a Mission Sustainability Framework (MSF) consisting of six metric categories: mission, installation management, neighbors and stakeholders, operations and maintenance, environment, and quality of life. Each of these categories was subdivided into varying numbers of what are called "issues and elements." Issues and elements were subdivided again into specific metrics.

The last step of the study's methodology was to “Develop a conceptual Sustainability Reporting Template that can be used as a 'dashboard' to monitor ... sustainability metrics ... in each MSF category..." (p. 7). However, that dashboard is never specifically discussed anywhere else in the report. The template suggests 86 conceptual metrics from which an installation may choose when developing its reporting system. The template does not provide a specific group of metrics that could be used as a dashboard in the vein of the set of installation sustainability indicators described herein. The 86 conceptual metrics listed are either too specific, do not actually measure an aspect of sustainability, or are not metrics at all. Many of the metrics measure the existence or magnitude of sustainability efforts, or

35 This report is available at http://handle.dtic.mil/100.2/ADA512929 (last accessed 3 Mar 2010) 
generally declare the existence of good intentions on the part of an installation.

\subsubsection{The College Sustainability Report Card}

The College Sustainability Report Card is a method of measuring the relative sustainability of college campuses. This measurement is carried out via a college's self-assessment by using a protocol developed for that purpose.

There are similarities between military installations and college campuses. Both operate with a focus on transient populations. In general, the buildings, housing, utilities, and other facilities of a campus and a cantonment area are analogous.

The protocol has nine categories under which there are a total of 48 indicators. Each indicator has a value, and the sum of those values under each category is used to score that category. The maximum score for a category is 100 points. Each of the nine categories is given a grade (A, B, C, D, or E) based on the number of points earned by addressing the indicators. The category grades are then averaged, and a score for the institution is awarded.

There are very few quantitative metrics for determining the grade of a category. Most of the indicators are Yes/ No type, meaning either something has been done or it hasn't. There are also extra credit points available if the something has been done really well, but awarding those seems to be subjective.

Setting goals and awarding points for achieving goals are not part of the protocol. Basically colleges are graded on the intensity of their good intentions. Because of the lack of quantifiable metrics, this grading system does not have indicators that the Army could use as indicators of sustainability.

\subsubsection{Executive Order 13514, Federal Leadership in Environmental, Energy, and Economic Performance, 5 October 2009}

EO 13514 contains broad policy directives and some quite specific goals for Federal agencies. These goals can be arranged within the following eight category topics.

1. Reduction in Green House Gas Emissions (3 goals) 
2. Reduction in Water Consumption (4 goals)

3. Pollution Prevention (P2) and Waste Elimination (10 goals)

4. Regional and Local Planning (5 goals)

5. Green Buildings (7goals)

6. Sustainable Acquisition (1 goal)

7. Electronics Stewardship (5 goals)

8. Environmental Management (2 goals)

Metrics are specified for some of the goals listed under topics 1- 5. The specified metrics may include, for example, a percentage reduction in resource consumption, in pollutant emissions, or an increase in waste diversion rates. A large number of the goals, ${ }^{36}$ however, simply require the federal agency to show some progress in a particular area from year to year.

With respect to our proposed indicators, we noticed no critical gaps except to note that our original set did not include any metric that addressed P2 and waste reduction. Our energy and water indicators will capture categories 1 and 2, respectively, while our waste indicator will capture categories 3 and 7. Infrastructure improvements, such as those that will result from an emphasis on green buildings, will be manifest in our energy and water indicators. Improvements brought about by sustainable acquisition policies and enhanced environmental management programs will also be taken into account under the indicators we propose.

\subsubsection{Army Sustainability Campaign Plan}

The ASCP is written at such a high level of abstraction that it will likely be easy to align any set of sustainability metrics or indicators with it. We do not see it as either harmful or helpful in developing a set of sustainability indicators, but it must be considered in all Army efforts because the Army intends it to be a capstone that embraces and unifies all the organization's efforts at becoming more sustainable.

\subsection{Consequences of the comparisons}

The major outcome of the several individual comparisons in this chapter was our decision to include an indicator (waste) that captures attempts at minimization, recycling, and pollution prevention. In order to be able to include it, an earlier proposed metric that focused on infrastructure was

36 The number of goals that require showing only some progress is 25 of 37 (68\%). 
deleted. In order to improve sustainability as measured by the water, energy, land, and waste indicators, an installation will necessarily make positive changes in the management of its infrastructure. 


\section{Conclusions and Recommendations}

The US Army is a leader in embracing sustainability as a goal. Over the years, the Army has continued to evolve its collective vision and its approaches to operationalize that vision. By initiating this report, IMCOM has embraced an approach that is not only unique, but also highly practical and resulted in a set of indicators designed to answer the question, "How sustainable are we?" This indicator set can serve to complement other existing approaches to sustainability by providing information that has rarely, if ever, been brought to bear in analysis and decision making.

The approach taken in the development of the indicators described in this report began with a team that was well acquainted with the Army's many sustainability efforts, and that approach then was broadened with a review of other organizations' approaches to capturing information about their sustainability. A set of criteria for the desired characteristics of indicators was developed; then an idealized list of potential indicators was proposed. Next, the ideal indicators were balanced against the available data that could be used to support them. A few indicators, such as the land indicator, proved straightforward to design; others, such as the well-being indicator, presented greater challenges.

At the same time this effort began to develop, IMCOM had been developing the Installation Management Campaign Plan (IMCP) that provides the Commander's vision and intent, an outline of tasks, and the metrics it will use to track those tasks. The installation sustainability indicators proposed in this report were designed to complement and reinforce the vision and intent of the IMCP. The IMCP will use the Army's Strategic Management System (SMS) to manage tasks and their metrics. SMS is the Army's enterprise, web-based system that provides a framework and methodology to enable Army leaders at all levels to manage performance. A majority of the data sources for the installation sustainability indicators are advertised as being incorporated in SMS. It is therefore logical that the way forward is to ensure that the installation sustainability indicators proposed herein are built into the SMS.

The application of the installation sustainability indicators in practice will need to be an iterative process. While some indicators can be readily im- 
plemented in SMS and sourced with data that are already there, others (e.g., well-being) will need some coordination to better mature the related data source.

It is also possible that IMCOM leadership may want to change the way some indicators are sourced or expressed. This discussion and evolution was anticipated and is the rationale for some of the extra content of this report that records the background research connected with each indicator. Thus, as the installation sustainability indicators are automated in the SMS, they can also be refined. When they are vetted and gain acceptance, the indicators can be institutionalized and used across the Army to ground more informed, relevant, and prioritized ISSP goals, and to produce an annual Army Sustainability Report that tracks efforts against trends in achieving sustainability.

It also is possible that the number of indicators may grow over time. IMCOM's initial vision for this project was to start with a small, manageable number of indicators because a manageable number of indicators would allow their utility to be demonstrated. Later, more indicators can be developed, especially as we learn about other available data that can support them.

In addition to the recommendations in Chapter 4 for sources for data to support the IMCOM indicators and the recommendation that SMS become the home for the indicators, it is recommended that IMCOM partner with The Well-Being Division of Army G1, Personnel, in the development of an installation sustainability indicator for well-being. 


\section{Appendix A: Approaches Compared}

In researching this report, we first determined attributes for ideal installation sustainability indicators and then prepared a list of preliminary indicators. In order to expose any deficiencies, those preliminary indicators were compared to metrics included in other approaches. The intention was to establish whether other approaches addressed a topic or topics important enough to require us to substitute it for one or more members of our set of possible indicators. Table A-1- Table A-5 exhibit the comparisons between our approach and the five alternative approaches listed here:

- The Tri-Services Sustainable Communities Scorecard (Table A-1)

- The SERDP-funded report by Alan Atkinson, David Berry, and Lee Hatcher (2009) entitled Sustainability Assessment of a Military Installation: A Template for Developing a Mission Sustainability Framework, Goals, Metrics, and Reporting System (Table A-2)

- The College Sustainability Report Card (Table A-3)

- Executive Order (EO) 13514, "Federal Leadership in Environmental, Energy, and Economic Performance," 5 October 2009 (Table A-4)

- The Army Sustainability Campaign Plan (Table A-5)

\section{Comparison with Tri-Services Sustainable Communities Scorecard}

Table A-1. The Tri-Services Sustainable Communities Scorecard credit table. ${ }^{37}$

\begin{tabular}{|c|c|c|c|}
\hline Credit Title & ID & $\begin{array}{l}\text { Topically } \\
\text { Relevant } \\
\text { CERL } \\
\text { Indicator }\end{array}$ & Metric \\
\hline \multicolumn{4}{|c|}{ Community Design and Development (CDD) } \\
\hline $\begin{array}{l}\text { Environmental Man- } \\
\text { agement Systems } \\
\text { (EMS) conformance }\end{array}$ & Req 1 & & $\begin{array}{l}\text { EMS must conform to require- } \\
\text { ments set forth by ISO 14001; } \\
\text { must also identify and show com- } \\
\text { pliance with all applicable regula- } \\
\text { tory permits }\end{array}$ \\
\hline $\begin{array}{l}\text { Asset management } \\
\text { plan }\end{array}$ & Req 2 & & $\begin{array}{l}\text { Establishment and maintenance of } \\
\text { a current plan in accordance with } \\
\text { EO 13327; components of the plan } \\
\text { are defined by EO and by example }\end{array}$ \\
\hline
\end{tabular}

37 Note: highlighted text indicates requirements (reproduced as presented in original draft). 


\begin{tabular}{|c|c|c|c|}
\hline Credit Title & ID & $\begin{array}{l}\text { Topically } \\
\text { Relevant } \\
\text { CERL } \\
\text { Indicator }\end{array}$ & Metric \\
\hline $\begin{array}{l}\text { Installation planning } \\
\text { profile }\end{array}$ & Req 3 & & $\begin{array}{l}\text { Installation Master Plan must be } \\
\text { current, thoroughly examined, re- } \\
\text { vised, and amended when neces- } \\
\text { sary; identify aspects that the plan } \\
\text { must include. }\end{array}$ \\
\hline $\begin{array}{l}\text { Sustainable design } \\
\text { standards }\end{array}$ & Credit 1 & & $\begin{array}{l}\text { Plan which includes: goal of LEED } \\
\text { Silver for all construction; use of } \\
\text { sustainable materials; cool } \\
\text { roof/high albedo roof specifica- } \\
\text { tions; water-efficient plumbing fix- } \\
\text { tures; advanced meters; facility } \\
\text { energy goals; use of WaterSense } \\
\text { Irrigation Contractor. }\end{array}$ \\
\hline Effective land use & Credit 2 & Land & $\begin{array}{l}\text { Change in acres of improved land, } \\
\text { semi-improved land, and unim- } \\
\text { proved land }\end{array}$ \\
\hline $\begin{array}{l}\text { Development near } \\
\text { existing infrastructure }\end{array}$ & Credit 3 & & $\begin{array}{l}\text { Consists of two parts: (a) New de- } \\
\text { velopment does not require exten- } \\
\text { sion of new roads and utility } \\
\text { transmission lines into previously } \\
\text { undeveloped land (increase in real } \\
\text { property records); (b) show a net } \\
\text { decrease in roads/utility transmis- } \\
\text { sion lines }\end{array}$ \\
\hline $\begin{array}{l}\text { Choices for getting } \\
\text { around }\end{array}$ & Credit 4 & & $\begin{array}{l}\text { Must meet (a) identification of pub- } \\
\text { lic transportation to the installa- } \\
\text { tion; (b) identification of on-base } \\
\text { public transportation which con- } \\
\text { nects to the external public trans- } \\
\text { portation }\end{array}$ \\
\hline $\begin{array}{l}\text { Shared-use pathway } \\
\text { network }\end{array}$ & Credit 5 & & $\begin{array}{l}\text { (a) Establish a comprehensive } \\
\text { pathway network plan; (b) percen- } \\
\text { tage execution of the plan }\end{array}$ \\
\hline $\begin{array}{l}\text { Brownfield redeve- } \\
\text { lopment }\end{array}$ & Credit 6 & & $\begin{array}{l}\text { (a) Identify the percentage of } \\
\text { brownfields remediated (no further } \\
\text { actions required) and/or (b) per- } \\
\text { centage of eligible brownfields re- } \\
\text { mediated using sustainable remed- } \\
\text { iation techniques. }\end{array}$ \\
\hline
\end{tabular}




\begin{tabular}{|l|l|l|l|}
\hline Credit Title & ID & $\begin{array}{l}\text { Topically } \\
\text { Relevant } \\
\text { CERL } \\
\text { Indicator }\end{array}$ & Metric \\
\hline Demolition & Credit 7 & & $\begin{array}{l}\text { Square footage of facilities demo- } \\
\text { lished }\end{array}$ \\
\hline $\begin{array}{l}\text { Heat island effect: } \\
\text { installation }\end{array}$ & Credit 8 & & $\begin{array}{l}\text { Using thermal images as a base- } \\
\text { line and identifying strategies to } \\
\text { reduce overall heat island effect for } \\
\text { roofs and non-roofs }\end{array}$ \\
\hline $\begin{array}{l}\text { Light pollution: instal- } \\
\text { lation }\end{array}$ & Credit 9 & Energy & $\begin{array}{l}\text { Use night-time lighting im- } \\
\text { ages/models to establish a base- } \\
\text { line and then show a decrease in } \\
\text { illumination (graduated scale); use } \\
\text { strategies such as full cut-off light- } \\
\text { ing or lighting curfew. }\end{array}$ \\
\hline Energy and Greenhouse Gases (EG) & Req 1 & $\begin{array}{l}\text { Energy } \\
\text { (partially) }\end{array}$ & $\begin{array}{l}\text { Provide baseline and annual inven- } \\
\text { tory of Scope 1, 2, and 3 GHG } \\
\text { emissions }\end{array}$ \\
\hline $\begin{array}{l}\text { GHG emissions ben- } \\
\text { chmarking and track- } \\
\text { ing }\end{array}$ & $\begin{array}{l}\text { Energy } \\
\text { Energy conservation: } \\
\text { installation }\end{array}$ & Req 2 & $\begin{array}{l}\text { Graduated scale based on a 2003 } \\
\text { baseline which exceeds 3\% per } \\
\text { year through 2015 (or 20\% total): } \\
\text { 2\% in 2009; 5\% in 2010; 8\% in } \\
\text { 2011; 11\% in 2012; 14\% in 2013; } \\
\text { 17\% in 2014; 20\% in 2015. }\end{array}$ \\
\hline $\begin{array}{l}\text { Refrigerant manage- } \\
\text { ment }\end{array}$ & Req 4 & Enewable energy: \\
installation & Req 3 & Energy & $\begin{array}{l}\text { Document that installation has met } \\
\text { renewable energy requirements: } \\
\text { 3\% for FY07-09; 5\% for FY10-12; } \\
7.5 \% \text { for FY13 and thereafter with } \\
\text { half coming from new renewable } \\
\text { energy sources. }\end{array}$ \\
\hline Energy management & Req 5 & Energy & $\begin{array}{l}\text { Phase out program of ozone dep- } \\
\text { leting chemicals (ODCs) for refrige- } \\
\text { rants OR maintenance program to } \\
\text { ensure proper charge levels are } \\
\text { maintained in all HVAC equipment }\end{array}$ \\
\hline $\begin{array}{l}\text { Does the installation have an } \\
\text { Energy Management Control Sys- } \\
\text { tem (EMCS) and is it benchmarking } \\
\text { collected meter readings? }\end{array}$ \\
\hline
\end{tabular}




\begin{tabular}{|c|c|c|c|}
\hline Credit Title & ID & $\begin{array}{l}\text { Topically } \\
\text { Relevant } \\
\text { CERL } \\
\text { Indicator }\end{array}$ & Metric \\
\hline $\begin{array}{l}\text { GHG Emissions Re- } \\
\text { duction }\end{array}$ & Credit 1 & $\begin{array}{l}\text { Energy } \\
\text { (partially) }\end{array}$ & $\begin{array}{l}\text { Graduated scale of reductions at } \\
2 \% \text { increments based on bench- } \\
\text { mark; can be achieved either for } \\
\text { total GHG emissions or under any } \\
\text { individual scope. }\end{array}$ \\
\hline $\begin{array}{l}\text { Increased Energy } \\
\text { Conservation, Instal- } \\
\text { lation }\end{array}$ & Credit 2 & Energy & $\begin{array}{l}\text { Graduated scale based on a } 2003 \\
\text { baseline which exceeds } 3 \% \text { per } \\
\text { year through } 2015 \text { (or } 20 \% \text { total): > } \\
2 \% \text { in } 2009 ;>5 \% \text { in } 2010 ;>8 \% \text { in } \\
2011 ;>11 \% \text { in } 2012 ;>14 \% \text { in } \\
2013 ;>17 \% \text { in } 2014 ;>20 \% \text { in } \\
2015 \text {, by } 2 \% \text { increments. }\end{array}$ \\
\hline $\begin{array}{l}\text { Increased renewable } \\
\text { energy, installation }\end{array}$ & Credit 3 & Energy & $\begin{array}{l}\text { Document that the installation has } \\
\text { exceeded renewable energy re- } \\
\text { quirements by } 2 \% \text { increments: } 3 \% \\
\text { for FY07-09; } 5 \% \text { for FY10-12; 7.5\% } \\
\text { for FY13 and thereafter with one- } \\
\text { half from new renewable energy } \\
\text { sources. }\end{array}$ \\
\hline $\begin{array}{l}\text { Carbon neutral instal- } \\
\text { lation }\end{array}$ & Credit 4 & & $\begin{array}{l}\text { Calculation showing annual GHG } \\
\text { emissions/energy consumption is } \\
\text { offset by carbon sequestration, re- } \\
\text { newable energy sources, and car- } \\
\text { bon-neutral energy sources. Points } \\
\text { awarded on a graduated scale } \\
\text { ranging from } 75 \%-100 \% \text { by } 5 \% \\
\text { increments. }\end{array}$ \\
\hline Advanced metering & Credit 5 & Energy & $\begin{array}{l}\text { Have meters been installed IAW AF } \\
\text { metering policy? }\end{array}$ \\
\hline $\begin{array}{l}\text { Electrical load / de- } \\
\text { mand efficiency }\end{array}$ & Credit 6 & Energy & To be determined \\
\hline \multicolumn{4}{|l|}{ Water Efficiency (WE) } \\
\hline Water use reduction & Req 1 & Water & $\begin{array}{l}2 \% \text { water reduction per year ( } 2007 \\
\text { as baseline year); or } 26 \% \text { by } 2020 \text {; } \\
\text { additional points given to exceed- } \\
\text { ing the requirement. }\end{array}$ \\
\hline
\end{tabular}




\begin{tabular}{|c|c|c|c|}
\hline Credit Title & ID & $\begin{array}{l}\text { Topically } \\
\text { Relevant } \\
\text { CERL } \\
\text { Indicator }\end{array}$ & Metric \\
\hline $\begin{array}{l}\text { Drinking water quality } \\
\text { management }\end{array}$ & $\operatorname{Req} 2$ & Water & $\begin{array}{l}\text { Show no primary drinking water } \\
\text { standards were exceeded in the } \\
\text { reporting year based on the con- } \\
\text { sumer confidence report and any } \\
\text { agency data call/report. }\end{array}$ \\
\hline $\begin{array}{l}\text { New construction } \\
\text { storm water man- } \\
\text { agement }\end{array}$ & $\operatorname{Req} 3$ & Water & $\begin{array}{l}\text { Document that all new construc- } \\
\text { tion projects must comply with this } \\
\text { policy [to preserve the pre- } \\
\text { development hydrology to the max- } \\
\text { imum extent possible on all new } \\
\text { construction projects (EISA07, } \\
\text { 438)] to the maximum extent tech- } \\
\text { nically feasible. }\end{array}$ \\
\hline $\begin{array}{l}\text { Wastewater man- } \\
\text { agement and reuse }\end{array}$ & Credit 1 & Water & $\begin{array}{l}\text { Reuse } 50 \% \text { of the installation's } \\
\text { wastewater OR treat } 50 \% \text { of the } \\
\text { installation's wastewater to tertiary } \\
\text { standards. }\end{array}$ \\
\hline $\begin{array}{l}\text { Stormwater man- } \\
\text { agement and reuse }\end{array}$ & Credit 2 & Water & $\begin{array}{l}\text { The installation must prevent the } \\
\text { off-site discharge of the precipita- } \\
\text { tion from all rainfall events less } \\
\text { than or equal to the 95th percen- } \\
\text { tile rainfall event. }\end{array}$ \\
\hline Water infrastructure & Credit 3 & Water & $\begin{array}{l}\text { The installation must have an } \mathrm{N}-1 \\
\text { or better rating in the annual Natu- } \\
\text { ral Infrastructure Assessment for } \\
\text { each of the specified categories. }\end{array}$ \\
\hline $\begin{array}{l}\text { Water rights docu- } \\
\text { mentation }\end{array}$ & Credit 4 & Water & $\begin{array}{l}\text { A completed water rights documen- } \\
\text { tation index has been prepared as } \\
\text { required by AF } 2009 \text { policy. }\end{array}$ \\
\hline $\begin{array}{l}\text { Minimize potable wa- } \\
\text { ter for landscaping }\end{array}$ & Credit 5 & Water & $\begin{array}{l}\text { Graduated scale: }<50 \% \text {; }<25 \% \text {; no } \\
\text { potable water }\end{array}$ \\
\hline $\begin{array}{l}\text { Minimize potable wa- } \\
\text { ter for golf course irri- } \\
\text { gation }\end{array}$ & Credit 6 & Water & $\begin{array}{l}\text { Graduated scale: }<50 \% \text {; }<25 \% \text {; no } \\
\text { potable water }\end{array}$ \\
\hline $\begin{array}{l}\text { Process water / grey } \\
\text { water management } \\
\text { and reuse }\end{array}$ & Credit 7 & Water & $\begin{array}{l}\text { Process waters and grey water is } \\
\text { reused at } 50 \% \text { or more of the facili- } \\
\text { ties where these process waters } \\
\text { exist. }\end{array}$ \\
\hline
\end{tabular}




\begin{tabular}{|c|c|c|c|}
\hline Credit Title & ID & $\begin{array}{l}\text { Topically } \\
\text { Relevant } \\
\text { CERL } \\
\text { Indicator }\end{array}$ & Metric \\
\hline \multicolumn{4}{|c|}{ Materials and Waste Management (MW) } \\
\hline $\begin{array}{l}\text { Hazardous waste } \\
\text { management }\end{array}$ & Req 1 & Waste & $\begin{array}{l}\text { Installation must have a HazWaste } \\
\text { Management Plan as required; the } \\
\text { plan must be reviewed and up- } \\
\text { dated regularly. }\end{array}$ \\
\hline $\begin{array}{l}\text { Integrated solid waste } \\
\text { management plan }\end{array}$ & Req 2 & Waste & $\begin{array}{l}\text { Plan must have all aspects as re- } \\
\text { quired; plan must be reviewed and } \\
\text { updated annually. }\end{array}$ \\
\hline $\begin{array}{l}\text { Electronics steward- } \\
\text { ship }\end{array}$ & Req 3 & Waste & $\begin{array}{l}\text { Policy must include guidance on } \\
\text { purchasing sustainable electronics } \\
\text { (e.g. Energy } \\
\text { Star, EPEAT, etc.). }\end{array}$ \\
\hline $\begin{array}{l}\text { Sustainable procure- } \\
\text { ment plan }\end{array}$ & Req 4 & Waste & $\begin{array}{l}\text { Plan must identify environmentally } \\
\text { preferable products, biobased } \\
\text { products, rapidly renewable, re- } \\
\text { cycled content, and low VOC. }\end{array}$ \\
\hline Solid waste reduction & Req 5 & Waste & $\begin{array}{l}\text { Divert } 50 \% \text { on non-hazwaste and } \\
\text { divert } 50 \% \text { of construc- } \\
\text { tion/demolition debris. }\end{array}$ \\
\hline $\begin{array}{l}\text { Hazmat reduction or } \\
\text { elimination }\end{array}$ & Credit 1 & Waste & $\begin{array}{l}\text { Percentage reduction in total ha- } \\
\text { zardous materials }\end{array}$ \\
\hline $\begin{array}{l}\text { Solid waste reduction: } \\
\text { above threshold }\end{array}$ & Credit 2 & Waste & $\begin{array}{l}\text { Graduated scale of percentage } \\
\text { above the federal requirement }\end{array}$ \\
\hline $\begin{array}{l}\text { Recycled Building Ma- } \\
\text { terials }\end{array}$ & Credit 3 & Waste & $\begin{array}{l}\text { Graduated scale of cubic yards of } \\
\text { materials used }\end{array}$ \\
\hline \multicolumn{4}{|c|}{ Natural Infrastructure (NI) } \\
\hline $\begin{array}{l}\text { Installation Natural } \\
\text { Resource Manage- } \\
\text { ment Plan (INRMP) }\end{array}$ & Req 1 & & $\begin{array}{l}\text { The Sikes Act (16 U.S.C. } 670 \text { ) and } \\
\text { DoD policy require all installations } \\
\text { with natural resources to maintain } \\
\text { an INRMP, and to keep the INRMP } \\
\text { current by review and update that } \\
\text { includes coordination with the } \\
\text { United States Fish and Wildlife } \\
\text { Service (USFWS), state fish and } \\
\text { wildlife management agency, and } \\
\text { installation commander no less } \\
\text { often than every } 5 \text { years. }\end{array}$ \\
\hline
\end{tabular}




\begin{tabular}{|c|c|c|c|}
\hline Credit Title & ID & $\begin{array}{l}\text { Topically } \\
\text { Relevant } \\
\text { CERL } \\
\text { Indicator }\end{array}$ & Metric \\
\hline $\begin{array}{l}\text { Installation Cultural } \\
\text { Resources Manage- } \\
\text { ment Plan (ICRMP) }\end{array}$ & Req 2 & & $\begin{array}{l}\text { The National Historical Preserva- } \\
\text { tion Act (NHPA) (16 U.S.C. } 470 \text { et } \\
\text { seq.) Section } 110 \text { and DOD policy } \\
\text { require the installation commander } \\
\text { to develop, update, and use the } \\
\text { ICRMP to define the cultural re- } \\
\text { sources program, plan for contin- } \\
\text { gencies, and comply with federal } \\
\text { laws and DoD policy to protect and } \\
\text { manage cultural resources. }\end{array}$ \\
\hline $\begin{array}{l}\text { Integrated Pest Man- } \\
\text { agement Plan (IPMP) }\end{array}$ & Req 3 & & $\begin{array}{l}\text { DODI } 4150.07 \text { and AFI 32-1053 } \\
\text { require an IPMP to be updated an- } \\
\text { nually and completely revised and } \\
\text { coordinated every five years. The } \\
\text { Plan describes an integrated pest } \\
\text { management approach by which } \\
\text { the installation will prevent pests } \\
\text { and disease vectors in accordance } \\
\text { with federal, state, and local laws. }\end{array}$ \\
\hline $\begin{array}{l}\text { Natural Infrastructure } \\
\text { Assessment (NIA) }\end{array}$ & Credit 1 & & $\begin{array}{l}\text { The installation is rated as } \mathrm{N}=0 \text { or } \\
\mathrm{N}=1\end{array}$ \\
\hline $\begin{array}{l}\text { Impact on the instal- } \\
\text { lation mission: } \\
\text { threatened and en- } \\
\text { dangered (T\&E) spe- } \\
\text { cies }\end{array}$ & $\begin{array}{l}\text { Credit } \\
2.1\end{array}$ & & $\begin{array}{l}\text { Graduated scale of acreage of as- } \\
\text { sociated critical habitat declined. }\end{array}$ \\
\hline $\begin{array}{l}\text { Impact on the instal- } \\
\text { lation mission: wild- } \\
\text { fire management }\end{array}$ & $\begin{array}{l}\text { Credit } \\
2.2\end{array}$ & & $\begin{array}{l}\text { The installation's wildland areas } \\
\text { meet the requirements of an ap- } \\
\text { proved strategy for reduction in } \\
\text { wildland fuels and wildfire risk mi- } \\
\text { tigation. }\end{array}$ \\
\hline $\begin{array}{l}\text { Impact on the instal- } \\
\text { lation mission: exotic } \\
\text { and invasive species }\end{array}$ & $\begin{array}{l}\text { Credit } \\
2.3\end{array}$ & & $\begin{array}{l}\text { Graduated scale of acreage of as- } \\
\text { sociated habitat declined }\end{array}$ \\
\hline $\begin{array}{l}\text { Impact on the instal- } \\
\text { lation mission: } \\
\text { bird/wildlife aircraft } \\
\text { strike hazard (BASH) } \\
\text { reduction }\end{array}$ & $\begin{array}{l}\text { Credit } \\
2.4\end{array}$ & & $\begin{array}{l}\text { Graduated scale of reduction in } \\
\text { BASH incidents }\end{array}$ \\
\hline
\end{tabular}




\begin{tabular}{|c|c|c|c|}
\hline Credit Title & ID & $\begin{array}{l}\text { Topically } \\
\text { Relevant } \\
\text { CERL } \\
\text { Indicator }\end{array}$ & Metric \\
\hline $\begin{array}{l}\text { Recovery of species } \\
\text { at risk }\end{array}$ & Credit 3 & & $\begin{array}{l}\text { Any species on the installation is } \\
\text { either delisted or downlisted on the } \\
\text { T\& E list due to actions by the in- } \\
\text { stallation. }\end{array}$ \\
\hline $\begin{array}{l}\text { Sustainable forest } \\
\text { management }\end{array}$ & Credit 4 & & $\begin{array}{l}\text { The installation's forests meet the } \\
\text { requirements of the Forest Ste- } \\
\text { wardship Council (FSC) or other } \\
\text { sustainable forest management } \\
\text { practices. }\end{array}$ \\
\hline $\begin{array}{l}\text { Effective urban fore- } \\
\text { stry }\end{array}$ & Credit 5 & & $\begin{array}{l}\text { The installation achieves the Na- } \\
\text { tional Arbor Day criteria to receive } \\
\text { "Tree City USA" certification. }\end{array}$ \\
\hline $\begin{array}{l}\text { Sustainable agricul- } \\
\text { ture management }\end{array}$ & Credit 6 & & $\begin{array}{l}\text { The installation's agricultural } \\
\text { areas/leases are managed in ac- } \\
\text { cordance with sustainability stan- } \\
\text { dards; document compliance. }\end{array}$ \\
\hline \multicolumn{4}{|l|}{ Built Infrastructure (BI) } \\
\hline $\begin{array}{l}\text { High-performance } \\
\text { sustainable buildings } \\
\text { (HPSB) }\end{array}$ & Req 1 & Energy & $\begin{array}{l}\text { Percentage of buildings (or square } \\
\text { footage) of facilities that meet the } \\
\text { requirements of HPSB; Building } \\
\text { centric aspects: day lighting, light- } \\
\text { ing controls, thermal com- } \\
\text { fort/ventilation, metering, commis- } \\
\text { sioning (including verifying the } \\
\text { facility energy model meets opera- } \\
\text { tional consumption). }\end{array}$ \\
\hline \multicolumn{4}{|l|}{ Vertical Construction } \\
\hline $\begin{array}{l}\text { HPSB: above thre- } \\
\text { shold }\end{array}$ & Credit 1 & & $\begin{array}{l}\text { Graduated scale: } 3 \% \text { by FY11; } 6 \% \\
\text { by FY12; } 9 \% \text { by FY14; } 15 \% \text { by FY15 }\end{array}$ \\
\hline $\begin{array}{l}\text { Certified green build- } \\
\text { ings }\end{array}$ & Credit 2 & & $\begin{array}{l}\text { Number of construction projects } \\
\text { receiving any certification of LEED } \\
\text { Gold or higher (NC or } \mathrm{Cl})\end{array}$ \\
\hline $\begin{array}{l}\text { Heat island effect: } \\
\text { roof }\end{array}$ & Credit 3 & & $\begin{array}{l}\text { Percentage of roof area on the in- } \\
\text { stallation that meets LEED re- } \\
\text { quirements for low heat island ef- } \\
\text { fect (i.e., minimizing the thermal } \\
\text { gradient caused by development, } \\
\text { namely roof reflectivity). }\end{array}$ \\
\hline
\end{tabular}




\begin{tabular}{|c|c|c|c|}
\hline Credit Title & ID & $\begin{array}{l}\text { Topically } \\
\text { Relevant } \\
\text { CERL } \\
\text { Indicator }\end{array}$ & Metric \\
\hline \multicolumn{4}{|c|}{ Horizontal Construction } \\
\hline $\begin{array}{l}\text { Heat island effect: } \\
\text { non-roof }\end{array}$ & Credit 4 & & $\begin{array}{l}\text { Percentage of pavement that } \\
\text { meets the LEED requirements for } \\
\text { low heat island effect }\end{array}$ \\
\hline Pavements: airfields & $\begin{array}{l}\text { Credit } \\
5.1\end{array}$ & & $\begin{array}{l}\text { Graduated scale of cumulative dol- } \\
\text { lar value of recycled content }\end{array}$ \\
\hline Pavements: roads & $\begin{array}{l}\text { Credit } \\
5.2\end{array}$ & & $\begin{array}{l}\text { Graduated scale of long feet of } \\
\text { road created or replaced with as- } \\
\text { phalt or concrete meeting a de- } \\
\text { fined threshold of re-cycled content }\end{array}$ \\
\hline Pavements: parking & $\begin{array}{l}\text { Credit } \\
5.3\end{array}$ & & $\begin{array}{l}\text { Graduated scale of square footage } \\
\text { / yardage of parking created or re- } \\
\text { placed with asphalt or concrete } \\
\text { that meets a defined threshold of } \\
\text { recycled content AND/OR amount } \\
\text { of open grid / porous pavement } \\
\text { used }\end{array}$ \\
\hline $\begin{array}{l}\text { Pavements: walks } \\
\text { and paths }\end{array}$ & $\begin{array}{l}\text { Credit } \\
5.4\end{array}$ & & $\begin{array}{l}\text { Graduated scale of long feet of } \\
\text { walks / paths created or replaced } \\
\text { with asphalt, concrete, or other } \\
\text { material meeting a defined thre- } \\
\text { shold of recycled content AND/OR } \\
\text { amount of open grid / porous } \\
\text { pavement used }\end{array}$ \\
\hline $\begin{array}{l}\text { Docks, bridges, and } \\
\text { other structures }\end{array}$ & $\begin{array}{l}\text { Credit } \\
5.5\end{array}$ & & **Placeholder** \\
\hline \multicolumn{4}{|l|}{ Lighting } \\
\hline $\begin{array}{l}\text { Exterior lighting effi- } \\
\text { ciency }\end{array}$ & Credit 6 & Energy & $\begin{array}{l}\text { Percentage of exterior lighting } \\
\text { meeting a specified lighting effi- } \\
\text { ciency (e.g., LED) -AND must not } \\
\text { exceed IESNA/OSHA lighting densi- } \\
\text { ty/levels }\end{array}$ \\
\hline $\begin{array}{l}\text { Exterior lighting con- } \\
\text { trols }\end{array}$ & Credit 7 & Energy & $\begin{array}{l}\text { Percentage of exterior lighting with } \\
\text { daylight controls AND must be on a } \\
\text { recurring commission- } \\
\text { ing/inspection program }\end{array}$ \\
\hline \multicolumn{4}{|l|}{ Space Optimization } \\
\hline $\begin{array}{l}\text { Space management } \\
\text { plan }\end{array}$ & Credit 8 & & $\begin{array}{l}\text { Having an approved and up-to-date } \\
\text { plan }\end{array}$ \\
\hline
\end{tabular}




\begin{tabular}{|c|c|c|c|}
\hline Credit Title & ID & $\begin{array}{l}\text { Topically } \\
\text { Relevant } \\
\text { CERL } \\
\text { Indicator }\end{array}$ & Metric \\
\hline $\begin{array}{l}\text { Adaptive reuse and } \\
\text { consolidation }\end{array}$ & Credit 9 & & $\begin{array}{l}\text { Percentage of facilities using adap- } \\
\text { tive reuse or consolidation }\end{array}$ \\
\hline \multicolumn{4}{|c|}{ Operations and Maintenance (O\&M) } \\
\hline $\begin{array}{l}\text { Certified green exist- } \\
\text { ing buildings, opera- } \\
\text { tions and mainten- } \\
\text { ance (EBOM) }\end{array}$ & Credit 10 & Energy & $\begin{array}{l}\text { Percentage or number of facilities } \\
\text { receiving certification for LEED } \\
\text { EBOM }\end{array}$ \\
\hline $\begin{array}{l}\text { Water fixture re- } \\
\text { placement program }\end{array}$ & Credit 11 & Energy & $\begin{array}{l}\text { O\&M program for replacement of } \\
\text { old fixtures with high-efficiency } \\
\text { ones }\end{array}$ \\
\hline $\begin{array}{l}\text { Light fixture replace- } \\
\text { ment program }\end{array}$ & Credit 12 & Energy & $\begin{array}{l}\text { O\&M program for replacement of } \\
\text { old lighting fixtures with new, high- } \\
\text { efficiency ones (both interior and } \\
\text { exterior) }\end{array}$ \\
\hline $\begin{array}{l}\text { Sustainable building } \\
\text { operations and main- } \\
\text { tenance plan }\end{array}$ & Credit 13 & & $\begin{array}{l}\text { Plan establishes goals for energy, } \\
\text { water, materials, recycling, and in- } \\
\text { door environmental quality; as- } \\
\text { sesses facilities and identifies } \\
\text { areas for improvement; identifies } \\
\text { avenues for occupant feedback on } \\
\text { workplace conditions/satisfaction; } \\
\text { identifies applicable AFIs/ETLs/fed } \\
\text { reqs; requires process water reduc- } \\
\text { tions to be considered in life-cycle } \\
\text { cost analysis. }\end{array}$ \\
\hline \multicolumn{4}{|l|}{ Transportation (T) } \\
\hline (no information) & & & \\
\hline \multicolumn{4}{|c|}{ Human Health, Development, and Productivity (HDP) } \\
\hline No-smoking policy & Req 1 & Well-Being & Document policy \\
\hline \multicolumn{4}{|c|}{ Community Engagement (CE) } \\
\hline Invasive Species Plan & Credit 1 & & Development of the plan \\
\hline \multicolumn{4}{|c|}{ Innovation and Regional (IR) } \\
\hline $\begin{array}{l}\text { Notices of Violation } \\
\text { (NOVs) }\end{array}$ & Credit 1 & & $\begin{array}{l}\text { Number of concurrent years since } \\
\text { last NOV (resets after an NOV is } \\
\text { received) }\end{array}$ \\
\hline
\end{tabular}




\section{Comparison with Atkinson SERDP-funded report}

According to page 13 of this report, '“Conceptual Metrics,'... are ideas for appropriate measures to assess the status and trend for a specific Issue or Element. Conceptual Metrics are topical rough drafts; they must be refined by analyzing available data, testing user comprehension, and other actions. Often, in practice, the envisioned metric must be replaced by indirect proxy measures that have better data or which communicate more effectively with the end-user or stakeholder." Fundamentally, then, it would seem that the metrics that are actually to be used against these conceptual ones are still to be determined.

Table A-2. Conceptual metrics from Atkinson SERDP report.

\begin{tabular}{|l|l|l|l|}
\hline Mission (MS) & Reference & $\begin{array}{l}\text { Topically } \\
\text { Relevant CERL } \\
\text { Indicator }\end{array}$ & $\begin{array}{l}\text { Specified } \\
\text { Metric }\end{array}$ \\
\hline Mission (MS) & MS1 & & \\
\hline CB Ops & MS2 & & \\
\hline Port Ops & MS3 & & \\
\hline Air Ops & MS4 & & \\
\hline Ops Support & MS5 & & \\
\hline $\begin{array}{l}\text { Fleet and family } \\
\text { readiness }\end{array}$ & MS6 & & \\
\hline Facility support & MS7 & $\begin{array}{l}\text { Water } \\
\text { Energy } \\
\text { Land } \\
\text { Waste }\end{array}$ & \\
\hline Environmental & Well-Being & \\
\hline Safety & MS8 & & \\
\hline Command and Staff & MS9 & & \\
\hline $\begin{array}{l}\text { Anti-Terrorism and Force } \\
\text { Protection }\end{array}$ & MS10 & Well-Being & \\
\hline $\begin{array}{l}\text { Emergency Prepared- } \\
\text { ness }\end{array}$ & MS11 & & \\
\hline Personnel & MS12 & & \\
\hline Equipment & MS13 & MS14 & \\
\hline Supply & MS15 & & \\
\hline Training & & & \\
\hline Ordnance & & & \\
\hline
\end{tabular}




\begin{tabular}{|l|l|l|l|}
\hline Mission (MS) & Reference & $\begin{array}{l}\text { Topically } \\
\text { Relevant CERL } \\
\text { Indicator }\end{array}$ & $\begin{array}{l}\text { Specified } \\
\text { Metric }\end{array}$ \\
\hline Facilities & MS17 & & \\
\hline Installation Management (MG) & MG1 & \\
\hline Billeting adequacy & MG2 & Well-Being & \\
\hline Civilian employment & MG3 & & \\
\hline Safety performance & MG4 & & \\
\hline Staffing levels & MG5 & & \\
\hline $\begin{array}{l}\text { Disaster preparedness } \\
\text { rating }\end{array}$ & MG6 & & \\
\hline Disaster readiness & MG7 & \\
\hline $\begin{array}{l}\text { Directives and instruc- } \\
\text { tions effectiveness }\end{array}$ & MG8 & & \\
\hline $\begin{array}{l}\text { Buildings certified as } \\
\text { sustainable }\end{array}$ & MG9 & Land & \\
\hline $\begin{array}{l}\text { Base master plan im- } \\
\text { plementation }\end{array}$ & Well-Being & \\
\hline Basic facility sufficiency & MG10 & & \\
\hline $\begin{array}{l}\text { Management tools ef- } \\
\text { fectiveness }\end{array}$ & MG11 & & \\
\hline $\begin{array}{l}\text { Management tool inte- } \\
\text { gration across base }\end{array}$ & MG12 & & \\
\hline Neighbors and Stakeholders (NS) & NS1 & & \\
\hline $\begin{array}{l}\text { “Walkable” on-base } \\
\text { community design }\end{array}$ & NS8 & \\
\hline $\begin{array}{l}\text { Alternative transporta- } \\
\text { tion utilization }\end{array}$ & NS2 & \\
\hline $\begin{array}{l}\text { Average commute time } \\
\text { for off-base personnel }\end{array}$ & NS3 & & \\
\hline $\begin{array}{l}\text { Alternative transporta- } \\
\text { tion performance }\end{array}$ & NS4 & & \\
\hline AlCUZ effectiveness & NS5 & & \\
\hline Encroachment index & NS6 & & \\
\hline $\begin{array}{l}\text { Enforcement actions } \\
\text { against installation }\end{array}$ & NS7 & & \\
\hline Land use planning & End & \\
\hline
\end{tabular}




\begin{tabular}{|c|c|c|c|}
\hline Mission (MS) & Reference & $\begin{array}{l}\text { Topically } \\
\text { Relevant CERL } \\
\text { Indicator }\end{array}$ & $\begin{array}{l}\text { Specified } \\
\text { Metric }\end{array}$ \\
\hline $\begin{array}{l}\text { Relationship with lo- } \\
\text { cal/regional zoning au- } \\
\text { thority }\end{array}$ & NS9 & Economy & \\
\hline $\begin{array}{l}\text { Community economic } \\
\text { impact of NBVC }\end{array}$ & NS10 & Economy & \\
\hline $\begin{array}{l}\text { Community perception } \\
\text { of NBVC }\end{array}$ & NS11 & Economy & \\
\hline $\begin{array}{l}\text { Direct impact on local } \\
\text { and regional business }\end{array}$ & NS12 & Economy & \\
\hline \multicolumn{4}{|c|}{ Operations and Maintenance (OM) } \\
\hline $\begin{array}{l}\text { Building maintenance } \\
\text { cost }\end{array}$ & OM1 & & \\
\hline Maintenance backlog & OM2 & & \\
\hline $\begin{array}{l}\text { Facilities performance } \\
\text { condition }\end{array}$ & OM3 & & \\
\hline $\begin{array}{l}\text { Sustainability retrofit } \\
\text { status }\end{array}$ & OM4 & & \\
\hline $\begin{array}{l}\text { Organic (natural) water } \\
\text { source capacity }\end{array}$ & OM5 & Water & \\
\hline $\begin{array}{l}\text { Water conservation im- } \\
\text { plementation }\end{array}$ & OM6 & Water & \\
\hline $\begin{array}{l}\text { Surface and groundwa- } \\
\text { ter status }\end{array}$ & OM7 & Water & \\
\hline $\begin{array}{l}\text { Regional water availabil- } \\
\text { ity }\end{array}$ & OM8 & Water & \\
\hline Water consumption & OM9 & Water & \\
\hline $\begin{array}{l}\text { Base electrical genera- } \\
\text { tion cost }\end{array}$ & OM10 & Energy & \\
\hline Base energy density & OM11 & Energy & \\
\hline Power reliability & OM12 & Energy & \\
\hline Renewable energy & OM13 & Energy & \\
\hline $\begin{array}{l}\text { Landscape mainten- } \\
\text { ance costs }\end{array}$ & OM14 & & \\
\hline Solid waste streams & OM15 & Waste & \\
\hline $\begin{array}{l}\text { On-base wastewater } \\
\text { treatment capacity }\end{array}$ & OM16 & & \\
\hline Wastewater volume & OM17 & & \\
\hline
\end{tabular}




\begin{tabular}{|l|l|l|l|l|}
\hline Mission (MS) & Reference & $\begin{array}{l}\text { Topically } \\
\text { Relevant CERL } \\
\text { Indicator }\end{array}$ & $\begin{array}{l}\text { Specified } \\
\text { Metric }\end{array}$ \\
\hline $\begin{array}{l}\text { On-base water reclama- } \\
\text { tion and reuse }\end{array}$ & OM18 & Water & \\
\hline Environment (EN) & \multicolumn{2}{|l|}{} \\
\hline $\begin{array}{l}\text { Greenhouse gas emis- } \\
\text { sions on-base }\end{array}$ & EN1 & $\begin{array}{l}\text { Energy } \\
\text { (partially) }\end{array}$ & \\
\hline $\begin{array}{l}\text { Greenhouse gas emis- } \\
\text { sions off-base }\end{array}$ & EN2 & $\begin{array}{l}\text { Energy } \\
\text { (partially) }\end{array}$ & \\
\hline $\begin{array}{l}\text { Air pollution non- } \\
\text { attainment days }\end{array}$ & EN3 & Waste & \\
\hline $\begin{array}{l}\text { Toxic emissions to air, } \\
\text { water, land }\end{array}$ & EN4 & Well-being & \\
\hline $\begin{array}{l}\text { Hazardous material } \\
\text { usage }\end{array}$ & EN5 & Well-being & \\
\hline $\begin{array}{l}\text { Habitat and species pro- } \\
\text { tection }\end{array}$ & EN6 & Well-being & \\
\hline $\begin{array}{l}\text { Endangered species } \\
\text { population recovery }\end{array}$ & EN7 & Well-being & \\
\hline Water consumption & EN8 & Well-being & \\
\hline Wastewater flow & EN9 & Water & \\
\hline $\begin{array}{l}\text { Non-point source pollu- } \\
\text { tion }\end{array}$ & EN10 & Water & \\
\hline Surface water quality & EN11 & Water & \\
\hline $\begin{array}{l}\text { Regional watershed } \\
\text { condition }\end{array}$ & EN12 & Water & \\
\hline Quality of Life (QL) & & QL1 & \\
\hline $\begin{array}{l}\text { Local community school } \\
\text { quality }\end{array}$ & QL3 & \\
\hline School adequacy & QL4 & \\
\hline Travel to schools & QL5 & \\
\hline $\begin{array}{l}\text { Housing accessibility on- } \\
\text { base and off-base }\end{array}$ & $\begin{array}{l} \\
\text { Off-base housing affor- } \\
\text { dability index } \\
\text { base and off-base }\end{array}$ & QL6 & \\
\hline
\end{tabular}




\begin{tabular}{|l|l|l|l|}
\hline Mission (MS) & Reference & $\begin{array}{l}\text { Topically } \\
\text { Relevant CERL } \\
\text { Indicator }\end{array}$ & $\begin{array}{l}\text { Specified } \\
\text { Metric }\end{array}$ \\
\hline $\begin{array}{l}\text { Housing sufficiency on- } \\
\text { base and off-base }\end{array}$ & QL7 & Well-being & \\
\hline $\begin{array}{l}\text { On-base housing availa- } \\
\text { bility }\end{array}$ & QL8 & Well-being & \\
\hline $\begin{array}{l}\text { Health care responsive- } \\
\text { ness }\end{array}$ & QL9 & Well-being & \\
\hline Health care satisfaction & QL10 & Well-being & \\
\hline $\begin{array}{l}\text { Public transportation to } \\
\text { health care facilities }\end{array}$ & QL11 & Well-being & \\
\hline $\begin{array}{l}\text { Travel to health care fa- } \\
\text { cilities }\end{array}$ & QL12 & Well-being & \\
\hline Child care accessibility & QL13 & Well-being & \\
\hline Child care satisfaction & QL14 & Well-being & \\
\hline $\begin{array}{l}\text { Quality, availability, and } \\
\text { accessibility of child } \\
\text { care }\end{array}$ & QL15 & Well-being & \\
\hline
\end{tabular}

\section{Comparison with College Sustainability Report Card}

The College Sustainability Report Card 38 has nine categories under which there are a total of 48 indicators. Each indicator is given a value, and the sum of those values under each category is 100. Each of the nine categories is given a grade (A, B, C, D, or E) based on the number of points earned from addressing the indicators. The grades for the nine categories are then averaged and a score for the institution is awarded.

There are very few quantitative metrics for determining the grade of a category. Most of the indicators are of the "yes/ no" type, meaning either something has been done or it hasn't. There are also extra-credit points available if a particular "something" has been done really well, but awarding extra-credit points appears subjective.

38 http://www.greenreportcard.org/ 
One thing that stands out due to its omission is a requirement to set goals and reward progress toward achieving them. Basically, colleges are graded on the intensity of their good intentions.

Table A-3. Comparison with College Sustainability Report Card.

\begin{tabular}{|c|c|c|}
\hline Category/Indicator & $\begin{array}{l}\text { Topically } \\
\text { Relevant CERL } \\
\text { Indicator }\end{array}$ & Specified Metric \\
\hline \multicolumn{3}{|l|}{ Administration } \\
\hline Sustainability policies & & $\begin{array}{l}\text { Formal policy; adopt } \\
\text { plans from higher levels }\end{array}$ \\
\hline Advisory council & & $\begin{array}{l}\text { Stakeholder advisory } \\
\text { council; accept student } \\
\text { input }\end{array}$ \\
\hline Sustainability staff & & $\begin{array}{l}\text { Designated staff; pro- } \\
\text { vide them adequate } \\
\text { funding }\end{array}$ \\
\hline Office or department & & $\begin{array}{l}\text { Focused on achieving } \\
\text { campus goals }\end{array}$ \\
\hline Website & & $\begin{array}{l}\text { Community involvement; } \\
\text { campus involvement. }\end{array}$ \\
\hline Green purchasing & & Formal policy \\
\hline \multicolumn{3}{|l|}{ Climate Change and Energy } \\
\hline GHG emissions inventory & $\begin{array}{l}\text { Energy } \\
\text { (partially) }\end{array}$ & Initiate and update \\
\hline $\begin{array}{l}\text { Commitment to GHG emissions } \\
\text { reduction }\end{array}$ & $\begin{array}{l}\text { Energy } \\
\text { (partially) }\end{array}$ & Formal commitment \\
\hline $\begin{array}{l}\text { Realized GHG emissions reduc- } \\
\text { tion }\end{array}$ & $\begin{array}{l}\text { Energy } \\
\text { (partially) }\end{array}$ & $\begin{array}{l}\text { Achieving a reduction } \\
\text { (per sq. ft. and per stu- } \\
\text { dent) }\end{array}$ \\
\hline Energy efficiency & Energy & $\begin{array}{l}\text { Use efficient systems; } \\
\text { upgrade existing sys- } \\
\text { tems }\end{array}$ \\
\hline Energy conservation & Energy & $\begin{array}{l}\text { Provide incentives to } \\
\text { reduce }\end{array}$ \\
\hline Renewable energy generation & Energy & $\begin{array}{l}\text { Install renewable } \\
\text { sources }\end{array}$ \\
\hline Renewable energy purchase & Energy & $\begin{array}{l}\text { Purchase renewable } \\
\text { power/credits; buy re- } \\
\text { newable non-electric }\end{array}$ \\
\hline
\end{tabular}




\begin{tabular}{|c|c|c|}
\hline Category/Indicator & $\begin{array}{l}\text { Topically } \\
\text { Relevant CERL } \\
\text { Indicator }\end{array}$ & Specified Metric \\
\hline On-site combustion & Energy & $\begin{array}{l}\text { Heating/cooling from } \\
\text { renewable sources }\end{array}$ \\
\hline \multicolumn{3}{|l|}{ Food \& Recycling } \\
\hline Locally grown and produced food & Economy & $\begin{array}{l}\text { Acquire food from }<150 \\
\text { miles }\end{array}$ \\
\hline $\begin{array}{l}\text { Organic and sustainably produced } \\
\text { food }\end{array}$ & & $\begin{array}{l}\text { Purchase sustainably } \\
\text { produced food; offer ve- } \\
\text { gan meals }\end{array}$ \\
\hline Fair trade products & & $\begin{array}{l}\text { Purchase fair trade } \\
\text { products }\end{array}$ \\
\hline $\begin{array}{l}\text { Dishware and eco-friendly incen- } \\
\text { tives }\end{array}$ & Waste & $\begin{array}{l}\text { Reusable dining hall } \\
\text { dishware; brown-bag in- } \\
\text { centives; eco-friendly } \\
\text { take-out containers }\end{array}$ \\
\hline $\begin{array}{l}\text { Food composting and waste di- } \\
\text { version }\end{array}$ & $\begin{array}{l}\text { Energy } \\
\text { Waste }\end{array}$ & $\begin{array}{l}\text { Compost food waste; } \\
\text { donate excess food; } \\
\text { trayless dining; recycle } \\
\text { cooking oil }\end{array}$ \\
\hline Recycling of traditional materials & Waste & $\begin{array}{l}\text { Administer recycling } \\
\text { program }\end{array}$ \\
\hline Recycling of electronic waste & Waste & $\begin{array}{l}\text { Provide recycling oppor- } \\
\text { tunity }\end{array}$ \\
\hline $\begin{array}{l}\text { Composting (aside from dining } \\
\text { facilities) }\end{array}$ & Waste & $\begin{array}{l}\text { Compost landscaping } \\
\text { waste; provide recep- } \\
\text { tacles for students }\end{array}$ \\
\hline Source reduction & Waste & $\begin{array}{l}\text { Programs to reuse } \\
\text { items; end of semester } \\
\text { clothing / furniture } \\
\text { swaps }\end{array}$ \\
\hline \multicolumn{3}{|l|}{ Green Building } \\
\hline Green building policy & & $\begin{array}{l}\text { Construction and demo- } \\
\text { lition policies }\end{array}$ \\
\hline Green building standards & $\begin{array}{l}\text { Water } \\
\text { Energy }\end{array}$ & Seek LEED certification \\
\hline Renovation and retrofits & $\begin{array}{l}\text { Water } \\
\text { Energy }\end{array}$ & $\begin{array}{l}\text { Renovate to LEED-EB, } \\
\text { Energy Star; retrofit with } \\
\text { energy / water conser- } \\
\text { vation devices }\end{array}$ \\
\hline
\end{tabular}




\begin{tabular}{|c|c|c|}
\hline Category/Indicator & $\begin{array}{l}\text { Topically } \\
\text { Relevant CERL } \\
\text { Indicator }\end{array}$ & Specified Metric \\
\hline \multicolumn{3}{|l|}{ Student Involvement } \\
\hline Residential communities & & $\begin{array}{l}\text { Offer sustainably } \\
\text { themed options }\end{array}$ \\
\hline New student orientation & & $\begin{array}{l}\text { Integrate sustainability } \\
\text { in orientation }\end{array}$ \\
\hline $\begin{array}{l}\text { Internships/outreach opportuni- } \\
\text { ties }\end{array}$ & & $\begin{array}{l}\text { Offer internship, student } \\
\text { position opportunities }\end{array}$ \\
\hline Student organizations & & $\begin{array}{l}\text { Active student orgs that } \\
\text { prioritize campus ef- } \\
\text { forts; student efforts } \\
\text { advance campus sus- } \\
\text { tainability }\end{array}$ \\
\hline $\begin{array}{l}\text { Sustainability challenges and } \\
\text { competitions }\end{array}$ & & $\begin{array}{l}\text { Campus sustainability } \\
\text { competitions at least } \\
\text { once per year }\end{array}$ \\
\hline \multicolumn{3}{|l|}{ Transportation } \\
\hline Campus motor fleet & Energy & $\begin{array}{l}\text { Fleet uses clean fuel; } \\
\text { minimize GHG on per- } \\
\text { passenger-mile-basis }\end{array}$ \\
\hline Local transportation alternatives & Energy & $\begin{array}{l}\text { Offer incentives to car- } \\
\text { pool, use public trans- } \\
\text { portation; provide } \\
\text { access to pub. trans. }\end{array}$ \\
\hline Bicycle program & Energy & $\begin{array}{l}\text { Offer bike rental, shar- } \\
\text { ing program, repair ser- } \\
\text { vice }\end{array}$ \\
\hline Car-sharing program & Energy & $\begin{array}{l}\text { Partner with a car- } \\
\text { sharing program }\end{array}$ \\
\hline Planning & Energy & $\begin{array}{l}\text { Implement policies for } \\
\text { pedestrian, bike-friendly } \\
\text { campus; parking poli- } \\
\text { cies that encourage alt. } \\
\text { transportation; achieve } \\
\text { low percentage of sin- } \\
\text { gle-person vehicles }\end{array}$ \\
\hline \multicolumn{3}{|l|}{ Endowment Transparency } \\
\hline \multicolumn{3}{|l|}{ Investment holdings } \\
\hline \multicolumn{3}{|l|}{ Proxy voting record } \\
\hline Accessibility & & \\
\hline
\end{tabular}




\begin{tabular}{|c|c|c|}
\hline Category/Indicator & $\begin{array}{l}\text { Topically } \\
\text { Relevant CERL } \\
\text { Indicator }\end{array}$ & Specified Metric \\
\hline \multicolumn{3}{|l|}{ Investment Priorities } \\
\hline \multicolumn{3}{|l|}{$\begin{array}{l}\text { Renewable energy and sustaina- } \\
\text { ble investments }\end{array}$} \\
\hline Community investment & Economy & $\begin{array}{l}\text { Invest in community de- } \\
\text { velopment loan funds, } \\
\text { etc. }\end{array}$ \\
\hline \multicolumn{3}{|l|}{ On-campus sustainability projects } \\
\hline \multicolumn{3}{|l|}{ Donor fund option } \\
\hline \multicolumn{3}{|l|}{ Optimizing investment return } \\
\hline \multicolumn{3}{|l|}{ Shareholder Engagement } \\
\hline \multicolumn{3}{|l|}{ Proxy vote decisions } \\
\hline Stakeholder involvement & & $\begin{array}{l}\text { Incorporate sharehold- } \\
\text { ers into investment ad- } \\
\text { visory process; include } \\
\text { faculty, student, and } \\
\text { alumni on adv. commit- } \\
\text { tee }\end{array}$ \\
\hline School community input & & $\begin{array}{l}\text { Encourage community } \\
\text { to provide input via fo- } \\
\text { rums or website }\end{array}$ \\
\hline Sustainability voting record & & \\
\hline
\end{tabular}




\section{Comparison with EO 13514}

Table A-4. Comparison with EO 13514. ${ }^{39}$

\begin{tabular}{|c|c|c|c|}
\hline EO Requirement & EO Section & $\begin{array}{l}\text { Topically } \\
\text { Relevant CERL } \\
\text { Indicator }\end{array}$ & $\begin{array}{l}\text { Specified } \\
\text { Metric }\end{array}$ \\
\hline \multicolumn{4}{|l|}{ Broad Policy Directives } \\
\hline Increase energy efficiency. & 1 & Energy & \\
\hline $\begin{array}{l}\text { Measure, report, and reduce } \\
\text { greenhouse gas emissions } \\
\text { from direct and indirect ac- } \\
\text { tivities. }\end{array}$ & 1 & $\begin{array}{l}\text { Energy } \\
\text { (partially) }\end{array}$ & \\
\hline $\begin{array}{l}\text { Conserve and protect water } \\
\text { resources through efficiency, } \\
\text { reuse, and stormwater man- } \\
\text { agement. }\end{array}$ & 1 & Water & \\
\hline $\begin{array}{l}\text { Eliminate waste, recycle, and } \\
\text { prevent pollution. }\end{array}$ & 1 & Waste & \\
\hline $\begin{array}{l}\text { Leverage agency acquisitions } \\
\text { to foster markets for sus- } \\
\text { tainable technologies and } \\
\text { environmentally preferable } \\
\text { materials, products, and ser- } \\
\text { vices. }\end{array}$ & 1 & $\begin{array}{l}\text { Economy } \\
\text { Waste }\end{array}$ & \\
\hline $\begin{array}{l}\text { Design, construct, maintain, } \\
\text { and operate high perfor- } \\
\text { mance sustainable buildings } \\
\text { in sustainable locations. }\end{array}$ & 1 & $\begin{array}{l}\text { Energy } \\
\text { Waste }\end{array}$ & \\
\hline $\begin{array}{l}\text { Strengthen the vitality and } \\
\text { livability of the communities } \\
\text { in which federal facilities are } \\
\text { located. }\end{array}$ & 1 & $\begin{array}{l}\text { Economy } \\
\text { Well-being }\end{array}$ & \\
\hline $\begin{array}{l}\text { Inform federal employees } \\
\text { about and involve them in } \\
\text { the achievement of these } \\
\text { goals. }\end{array}$ & 1 & & \\
\hline $\begin{array}{l}\text { Prioritize actions based on a } \\
\text { full accounting of both eco- } \\
\text { nomic and social benefits } \\
\text { and costs. }\end{array}$ & 1 & & \\
\hline
\end{tabular}

39 Executive Order 13514 "Federal Leadership in Environmental, Energy, and Economic Performance", signed 5 October 2009. http://www.fedcenter.gov/programs/eo13514/ 


\begin{tabular}{|c|c|c|c|}
\hline EO Requirement & EO Section & $\begin{array}{l}\text { Topically } \\
\text { Relevant CERL } \\
\text { Indicator }\end{array}$ & $\begin{array}{l}\text { Specified } \\
\text { Metric }\end{array}$ \\
\hline $\begin{array}{l}\text { Drive continuous improve- } \\
\text { ment by annually evaluating } \\
\text { performance, extending or } \\
\text { expanding projects that have } \\
\text { net benefits and reassessing } \\
\text { or discontinuing under- } \\
\text { performing projects. }\end{array}$ & 1 & & \\
\hline $\begin{array}{l}\text { Be transparent and disclose } \\
\text { results associated with the } \\
\text { actions taken pursuant to } \\
\text { this order on publicly availa- } \\
\text { ble federal websites. }\end{array}$ & 1 & & \\
\hline \multicolumn{4}{|l|}{ Goals for agencies: GHG } \\
\hline $\begin{array}{l}\text { Establish and report a per- } \\
\text { centage reduction target for } \\
\text { agency-wide reductions of } \\
\text { Scope } 1 \text { and } 2 \text { greenhouse } \\
\text { gas emissions in absolute } \\
\text { terms by FY } 2020 \text {, relative to } \\
\text { a FY } 2008 \text { baseline of the } \\
\text { agency's Scope } 1 \text { and } 2 \\
\text { greenhouse gas emissions. }\end{array}$ & $2 a$ & $\begin{array}{l}\text { Energy } \\
\text { (partially) }\end{array}$ & $\begin{array}{l}\text { Percentage } \\
\text { reductions } \\
\text { versus } \\
\text { FY } 2008 \\
\text { baseline }\end{array}$ \\
\hline $\begin{array}{l}\text { Establish and report a per- } \\
\text { centage reduction target for } \\
\text { reducing agency-wide Scope } \\
3 \text { greenhouse gas emissions } \\
\text { in absolute terms by fiscal } \\
\text { year } 2020 \text {, relative to a fiscal } \\
\text { year } 2008 \text { baseline of agen- } \\
\text { cy Scope } 3 \text { emissions. }\end{array}$ & $2 b$ & $\begin{array}{l}\text { Energy } \\
\text { (partially) }\end{array}$ & $\begin{array}{l}\text { Percentage } \\
\text { reductions vs. } \\
\text { FY2008 base- } \\
\text { line }\end{array}$ \\
\hline $\begin{array}{l}\text { Establish and report a com- } \\
\text { prehensive inventory of ab- } \\
\text { solute greenhouse gas emis- } \\
\text { sions, including Scope 1, } \\
\text { Scope 2, and specified } \\
\text { Scope } 3 \text { emissions (i) within } \\
15 \text { months of the date of this } \\
\text { order for FY 2010, and (ii) } \\
\text { thereafter, annually at the } \\
\text { end of January, for the pre- } \\
\text { ceding fiscal year. }\end{array}$ & $2 c$ & $\begin{array}{l}\text { Energy } \\
\text { (partially) }\end{array}$ & $\begin{array}{l}\text { Inventory } \\
\text { complete } \\
\text { within } 15 \text { mo } \\
\text { of } 5 \text { OCT } 09 \\
\text { for } 2010 ; \text { an- } \\
\text { nually the- } \\
\text { reafter }\end{array}$ \\
\hline
\end{tabular}




\begin{tabular}{|c|c|c|c|}
\hline EO Requirement & EO Section & $\begin{array}{l}\text { Topically } \\
\text { Relevant CERL } \\
\text { Indicator }\end{array}$ & $\begin{array}{l}\text { Specified } \\
\text { Metric }\end{array}$ \\
\hline \multicolumn{4}{|l|}{ Goals for agencies: Water } \\
\hline $\begin{array}{l}\text { Reduce potable water con- } \\
\text { sumption intensity by } 2 \% \\
\text { annually through FY } 2020 \text {, or } \\
26 \% \text { by the end of FY } 2020 \text {, } \\
\text { relative to a baseline of the } \\
\text { agency's water consumption } \\
\text { in FY } 2007 \text {, by implementing } \\
\text { water management strate- } \\
\text { gies including water-efficient } \\
\text { and low-flow fixtures and ef- } \\
\text { ficient cooling towers. }\end{array}$ & $2 d$ & Water & $\begin{array}{l}2 \% \text { consump- } \\
\text { tion reduction } \\
\text { annually } \\
\text { through } 2020 \\
\text { or } 26 \% \text { by the } \\
\text { end of } \\
\text { FY2020 rela- } \\
\text { tive to } \\
\text { FY2007 base- } \\
\text { line }\end{array}$ \\
\hline $\begin{array}{l}\text { Reduce agency industrial, } \\
\text { landscaping, and agricultural } \\
\text { water consumption by } 2 \% \\
\text { annually or } 20 \% \text { by the end } \\
\text { of FY } 2020 \text { relative to a } \\
\text { baseline of the agency's in- } \\
\text { dustrial, landscaping, and } \\
\text { agricultural water consump- } \\
\text { tion in FY } 2010 \text {. }\end{array}$ & $2 d$ & Water & $\begin{array}{l}2 \% \text { consump- } \\
\text { tion reduction } \\
\text { annually } \\
\text { through } 2020 \\
\text { or } 26 \% \text { by the } \\
\text { end of } \\
\text { FY2020 rela- } \\
\text { tive to FY07 } \\
\text { baseline }\end{array}$ \\
\hline $\begin{array}{l}\text { Identify, promote, and im- } \\
\text { plement water reuse strate- } \\
\text { gies that reduce potable wa- } \\
\text { ter consumption. }\end{array}$ & $2 d$ & Water & $\begin{array}{l}\text { None - show } \\
\text { progress }\end{array}$ \\
\hline $\begin{array}{l}\text { Implement and achieve the } \\
\text { objectives identified in the } \\
\text { storm water management } \\
\text { guidance referenced in Sec- } \\
\text { tion } 14 \text { of this order. }\end{array}$ & $2 \mathrm{~d}$ and 14 & Water & $\begin{array}{l}\text { None - show } \\
\text { progress }\end{array}$ \\
\hline \multicolumn{4}{|c|}{ Goals for Agencies: P2 / Waste Elimination } \\
\hline $\begin{array}{l}\text { Minimize the generation of } \\
\text { waste and pollutants through } \\
\text { source reduction. }\end{array}$ & $2 e$ & Waste & $\begin{array}{l}\text { None - show } \\
\text { progress }\end{array}$ \\
\hline $\begin{array}{l}\text { Divert at least } 50 \% \text { of non- } \\
\text { hazardous solid waste, ex- } \\
\text { cluding construction and } \\
\text { demolition debris, by the end } \\
\text { of FY } 2015 \text {. }\end{array}$ & $2 e$ & Waste & $\begin{array}{l}\text { At least } 50 \% \\
\text { diversion by } \\
\text { the end of } \\
\text { FY2015 }\end{array}$ \\
\hline
\end{tabular}




\begin{tabular}{|l|l|l|l|}
\hline EO Requirement & EO Section & $\begin{array}{l}\text { Topically } \\
\text { Relevant CERL } \\
\text { Indicator }\end{array}$ & $\begin{array}{l}\text { Specified } \\
\text { Metric }\end{array}$ \\
\hline $\begin{array}{l}\text { Divert at least 50\% of con- } \\
\text { struction and demolition ma- } \\
\text { terials and debris by the end } \\
\text { of FY 2015. }\end{array}$ & $2 \mathrm{e}$ & Waste & $\begin{array}{l}\text { At least 50\% } \\
\text { diversion by } \\
\text { the end of } \\
\text { FY2015 }\end{array}$ \\
\hline $\begin{array}{l}\text { Reduce printing paper use } \\
\text { and acquiring uncoated } \\
\text { printing and writing paper } \\
\text { containing at least 30\% } \\
\text { postconsumer fiber. }\end{array}$ & $2 \mathrm{e}$ & Waste & $\begin{array}{l}\text { None - show } \\
\text { progress }\end{array}$ \\
\hline $\begin{array}{l}\text { Reduce and minimize the } \\
\text { quantity of toxic and hazard- } \\
\text { ous chemicals and materials } \\
\text { acquired, used, or disposed. }\end{array}$ & $2 \mathrm{e}$ & Waste & $\begin{array}{l}\text { None - show } \\
\text { progress }\end{array}$ \\
\hline $\begin{array}{l}\text { Increase diversion of com- } \\
\text { postable and organic ma- } \\
\text { terial from the waste stream. }\end{array}$ & $2 \mathrm{e}$ & Waste & $\begin{array}{l}\text { None - show } \\
\text { progress }\end{array}$ \\
\hline $\begin{array}{l}\text { Implement integrated pest } \\
\text { management and other ap- } \\
\text { propriate landscape man- } \\
\text { agement practices. }\end{array}$ & $2 \mathrm{e}$ & & $\begin{array}{l}\text { None - show } \\
\text { progress }\end{array}$ \\
\hline $\begin{array}{l}\text { Increase use of acceptable } \\
\text { alternative chemicals and } \\
\text { processes in keeping with } \\
\text { the agency's procurement } \\
\text { policies. }\end{array}$ & $2 \mathrm{e}$ & Waste & $\begin{array}{l}\text { None - show } \\
\text { progress }\end{array}$ \\
\hline $\begin{array}{l}\text { Decrease use of chemicals } \\
\text { where such decrease will as- } \\
\text { sist the agency in achieving } \\
\text { greenhouse gas emission } \\
\text { reduction targets. }\end{array}$ & $2 \mathrm{e}$ & & $\begin{array}{l}\text { None - show } \\
\text { progress }\end{array}$ \\
\hline $\begin{array}{l}\text { Report in accordance with } \\
\text { EPCRA. }\end{array}$ & $2 \mathrm{e}$ & $\begin{array}{l}\text { None - show } \\
\text { progress }\end{array}$ \\
\hline
\end{tabular}




\begin{tabular}{|c|c|c|c|}
\hline EO Requirement & EO Section & $\begin{array}{l}\text { Topically } \\
\text { Relevant CERL } \\
\text { Indicator }\end{array}$ & $\begin{array}{l}\text { Specified } \\
\text { Metric }\end{array}$ \\
\hline \multicolumn{4}{|c|}{ Goals for Agencies: Regional / Local Planning } \\
\hline $\begin{array}{l}\text { Participate in regional trans- } \\
\text { portation planning and re- } \\
\text { cognizing existing community } \\
\text { transportation infrastructure }\end{array}$ & $2 f$ & Energy & $\begin{array}{l}\text { None - show } \\
\text { progress }\end{array}$ \\
\hline $\begin{array}{l}\text { Align federal policies to in- } \\
\text { crease the effectiveness of } \\
\text { local planning for energy } \\
\text { choices such as locally gen- } \\
\text { erated renewable energy }\end{array}$ & $2 f$ & Energy & $\begin{array}{l}\text { None - show } \\
\text { progress }\end{array}$ \\
\hline $\begin{array}{l}\text { Ensure that planning for new } \\
\text { federal facilities or new leas- } \\
\text { es includes consideration of } \\
\text { sites that are pedestrian } \\
\text { friendly, near existing em- } \\
\text { ployment centers, and ac- } \\
\text { cessible to public transit, and } \\
\text { emphasizes existing central } \\
\text { cities and, in rural communi- } \\
\text { ties, existing or planned town } \\
\text { centers }\end{array}$ & $2 f$ & $\begin{array}{l}\text { Energy } \\
\text { Well-being }\end{array}$ & $\begin{array}{l}\text { None - show } \\
\text { progress }\end{array}$ \\
\hline $\begin{array}{l}\text { Identify and analyze impacts } \\
\text { from energy usage and alter- } \\
\text { native energy sources in all } \\
\text { Environmental Impact } \\
\text { Statements and Environmen- } \\
\text { tal Assessments for propos- } \\
\text { als for new or expanded Fed- } \\
\text { eral facilities }\end{array}$ & $2 f$ & Energy & $\begin{array}{l}\text { None - show } \\
\text { progress }\end{array}$ \\
\hline $\begin{array}{l}\text { Coordinate with regional pro- } \\
\text { grams for federal, state, tri- } \\
\text { bal, and local ecosystem, wa- } \\
\text { tershed, and environmental } \\
\text { management }\end{array}$ & $2 f$ & & $\begin{array}{l}\text { None - show } \\
\text { progress }\end{array}$ \\
\hline
\end{tabular}




\begin{tabular}{|c|c|c|c|}
\hline EO Requirement & EO Section & \begin{tabular}{|l|} 
Topically \\
Relevant CERL \\
Indicator
\end{tabular} & \begin{tabular}{|l} 
Specified \\
Metric
\end{tabular} \\
\hline \multicolumn{4}{|l|}{ Goals for Agencies: Buildings } \\
\hline $\begin{array}{l}\text { Ensure that all new federal } \\
\text { buildings that enter the } \\
\text { planning process are de- } \\
\text { signed to achieve zero-net- } \\
\text { energy by } 2030\end{array}$ & $2 g$ & Energy & $\begin{array}{l}\text { Starting with } \\
\text { buildings that } \\
\text { enter plan- } \\
\text { ning process } \\
\text { in } 2020, \text { zero- } \\
\text { net-energy by } \\
2030\end{array}$ \\
\hline $\begin{array}{l}\text { Ensure that all new construc- } \\
\text { tion, major renovation, or re- } \\
\text { pair and alteration of Federal } \\
\text { buildings complies with the } \\
\text { Guiding Principles for Federal } \\
\text { Leadership in High Perfor- } \\
\text { mance and Sustainable } \\
\text { Buildings, (Guiding Prin- } \\
\text { ciples) }\end{array}$ & $2 g$ & $\begin{array}{l}\text { Energy } \\
\text { Waste }\end{array}$ & $\begin{array}{l}100 \% \text { com- } \\
\text { pliance of all } \\
\text { new construc- } \\
\text { tion, major } \\
\text { renovation, or } \\
\text { repair and al- } \\
\text { teration }\end{array}$ \\
\hline $\begin{array}{l}\text { Ensure that at least } 15 \% \text { of } \\
\text { the agency's existing build- } \\
\text { ings (above 5,000 gross sq } \\
\mathrm{ft} \text { ) and building leases } \\
\text { (above 5,000 gross sq ft) } \\
\text { meet the Guiding Principles } \\
\text { by fiscal year } 2015 \text { and that } \\
\text { the agency makes annual } \\
\text { progress toward } 100 \% \text { con- } \\
\text { formance with the Guiding } \\
\text { Principles for its building in- } \\
\text { ventory }\end{array}$ & $2 g$ & Energy & $\begin{array}{l}\text { 15\% of exist- } \\
\text { ing buildings } \\
\text { meet Guiding } \\
\text { Principles by } \\
\text { 2015; annual } \\
\text { progress to- } \\
\text { ward } 100 \% \\
\text { conformance } \\
\text { with the Guid- } \\
\text { ing Principles } \\
\text { for its building } \\
\text { inventory }\end{array}$ \\
\hline $\begin{array}{l}\text { Pursue cost-effective, inno- } \\
\text { vative strategies, such as } \\
\text { highly reflective and vege- } \\
\text { tated roofs, to minimize con- } \\
\text { sumption of energy, water, } \\
\text { and materials }\end{array}$ & $2 g$ & $\begin{array}{l}\text { Energy } \\
\text { Water } \\
\text { Waste }\end{array}$ & $\begin{array}{l}\text { None - show } \\
\text { progress }\end{array}$ \\
\hline $\begin{array}{l}\text { Manage existing building sys- } \\
\text { tems to reduce the consump- } \\
\text { tion of energy, water, and } \\
\text { materials, and identifying } \\
\text { alternatives to renovation } \\
\text { that reduce existing assets' } \\
\text { deferred maintenance costs }\end{array}$ & $2 g$ & $\begin{array}{l}\text { Energy } \\
\text { Water } \\
\text { Waste }\end{array}$ & $\begin{array}{l}\text { None - show } \\
\text { progress }\end{array}$ \\
\hline
\end{tabular}




\begin{tabular}{|c|c|c|c|}
\hline EO Requirement & EO Section & $\begin{array}{l}\text { Topically } \\
\text { Relevant CERL } \\
\text { Indicator }\end{array}$ & $\begin{array}{l}\text { Specified } \\
\text { Metric }\end{array}$ \\
\hline $\begin{array}{l}\text { Identify opportunities to con- } \\
\text { solidate and dispose of exist- } \\
\text { ing assets, optimize the per- } \\
\text { formance of the agency's } \\
\text { real-property portfolio, and } \\
\text { reduce associated environ- } \\
\text { mental impacts, when add- } \\
\text { ing assets to the agency's } \\
\text { real property inventory }\end{array}$ & $2 g$ & $\begin{array}{l}\text { Energy } \\
\text { Land }\end{array}$ & $\begin{array}{l}\text { None - show } \\
\text { progress }\end{array}$ \\
\hline $\begin{array}{l}\text { Ensure that rehabilitation of } \\
\text { federally owned historic } \\
\text { buildings utilizes best prac- } \\
\text { tices and technologies in re- } \\
\text { trofitting to promote long- } \\
\text { term viability of the buildings }\end{array}$ & $2 g$ & $\begin{array}{l}\text { Energy } \\
\text { Waste }\end{array}$ & $\begin{array}{l}\text { None - show } \\
\text { progress }\end{array}$ \\
\hline \multicolumn{4}{|c|}{ Goals for Agencies: Sustainable Acquisition } \\
\hline $\begin{array}{l}\text { Ensure that } 95 \text { percent of } \\
\text { new contract actions (includ- } \\
\text { ing task and delivery orders) } \\
\text { for products and services } \\
\text { with the exception of acquisi- } \\
\text { tion of weapon systems, are } \\
\text { energy-efficient (Energy Star } \\
\text { or Federal Energy Manage- } \\
\text { ment Program (FEMP) desig- } \\
\text { nated), water-efficient, bio- } \\
\text { based, environmentally } \\
\text { preferable (e.g., Electronic } \\
\text { Product Environmental As- } \\
\text { sessment Tool [EPEAT] certi- } \\
\text { fied), non-ozone depleting, } \\
\text { contain recycled content, or } \\
\text { are non-toxic or less toxic al- } \\
\text { ternatives, where such prod- } \\
\text { ucts and services meet } \\
\text { agency performance re- } \\
\text { quirements }\end{array}$ & $2 \mathrm{~h}$ & $\begin{array}{l}\text { Water } \\
\text { Energy } \\
\text { Waste }\end{array}$ & $\begin{array}{l}95 \% \text { of new } \\
\text { contract ac- } \\
\text { tions (includ- } \\
\text { ing task and } \\
\text { delivery or- } \\
\text { ders) for } \\
\text { products and } \\
\text { services with } \\
\text { the exception } \\
\text { of acquisition } \\
\text { of weapon } \\
\text { systems, are } \\
\text { energy- } \\
\text { efficient }\end{array}$ \\
\hline \multicolumn{4}{|c|}{ Goals for Agencies: Electronics Stewardship } \\
\hline $\begin{array}{l}\text { Ensure procurement prefe- } \\
\text { rence for EPEAT-registered } \\
\text { electronic products; }\end{array}$ & $2 \mathrm{i}$ & Waste & $\begin{array}{l}\text { None - Show } \\
\text { Progress }\end{array}$ \\
\hline
\end{tabular}




\begin{tabular}{|c|c|c|c|}
\hline EO Requirement & EO Section & $\begin{array}{l}\text { Topically } \\
\text { Relevant CERL } \\
\text { Indicator }\end{array}$ & $\begin{array}{l}\text { Specified } \\
\text { Metric }\end{array}$ \\
\hline $\begin{array}{l}\text { Establish and implement pol- } \\
\text { icies to enable power man- } \\
\text { agement, duplex printing, } \\
\text { and other energy-efficient or } \\
\text { environmentally preferable } \\
\text { features on all eligible agen- } \\
\text { cy electronic products. }\end{array}$ & $2 i$ & $\begin{array}{l}\text { Energy } \\
\text { Waste }\end{array}$ & $\begin{array}{l}\text { None - Show } \\
\text { Progress }\end{array}$ \\
\hline $\begin{array}{l}\text { Employ environmentally } \\
\text { sound practices with respect } \\
\text { to the agency's disposition of } \\
\text { all agency excess or surplus } \\
\text { electronic products }\end{array}$ & $2 i$ & Waste & $\begin{array}{l}\text { None - Show } \\
\text { Progress }\end{array}$ \\
\hline $\begin{array}{l}\text { Ensure the procurement of } \\
\text { Energy Star and FEMP des- } \\
\text { ignated electronic equipment }\end{array}$ & $2 \mathrm{i}$ & Energy & $\begin{array}{l}\text { None - Show } \\
\text { Progress }\end{array}$ \\
\hline $\begin{array}{l}\text { Implement best manage- } \\
\text { ment practices for energy- } \\
\text { efficient management of } \\
\text { servers and Federal data } \\
\text { centers }\end{array}$ & $2 \mathrm{i}$ & Energy & $\begin{array}{l}\text { None - Show } \\
\text { Progress }\end{array}$ \\
\hline \multicolumn{4}{|c|}{ Goals for Agencies: Environmental Management } \\
\hline $\begin{array}{l}\text { Continue implementation of } \\
\text { formal environmental man- } \\
\text { agement systems at all ap- } \\
\text { propriate organizational le- } \\
\text { vels }\end{array}$ & $2 \mathrm{j}$ & & $\begin{array}{l}\text { None - Show } \\
\text { Progress }\end{array}$ \\
\hline $\begin{array}{l}\text { Ensure these formal systems } \\
\text { are appropriately imple- } \\
\text { mented and maintained to } \\
\text { achieve the performance ne- } \\
\text { cessary to meet the goals of } \\
\text { this order. }\end{array}$ & $2 \mathrm{j}$ & & $\begin{array}{l}\text { None - Show } \\
\text { Progress }\end{array}$ \\
\hline
\end{tabular}


Comparison with Army Sustainability Campaign Plan

Table A-5. Army Sustainability Campaign Plan

(Concurrence Draft of 1 OCT 09).

\begin{tabular}{|c|c|c|c|}
\hline $\begin{array}{l}\text { Area of Coordination and } \\
\text { Execution }\end{array}$ & ASCP Reference & $\begin{array}{l}\text { Topically } \\
\text { Relevant CERL } \\
\text { Indicator }\end{array}$ & $\begin{array}{l}\text { Specified } \\
\text { Metric }\end{array}$ \\
\hline Energy & $3(g)(2)(a)$ & Energy & \\
\hline Water & $3(g)(2)(b)$ & $\begin{array}{l}\text { Water } \\
\text { Land }\end{array}$ & \\
\hline $\begin{array}{l}\text { Planning and Conserva- } \\
\text { tion }\end{array}$ & $3(g)(3)$ & $\begin{array}{l}\text { Water } \\
\text { Land }\end{array}$ & \\
\hline Waste & $3(g)(4)$ & Waste & \\
\hline Air & $3(g)(5)$ & $\begin{array}{l}\text { Energy } \\
\text { (partially) }\end{array}$ & \\
\hline $\begin{array}{l}\text { Interagency, Intergo- } \\
\text { vernmental, Public, and } \\
\text { Private Cooperation }\end{array}$ & $3(g)(6)$ & Economy & \\
\hline Contingency Operations & $3(g)(7)$ & $\begin{array}{l}\text { Water } \\
\text { Energy } \\
\text { Land } \\
\text { Waste }\end{array}$ & \\
\hline $\begin{array}{l}\text { Acquisition and Pro- } \\
\text { curement }\end{array}$ & $3(g)(8)$ & $\begin{array}{l}\text { Water } \\
\text { Energy } \\
\text { Land }\end{array}$ & \\
\hline \multicolumn{4}{|l|}{ Lines of Operation } \\
\hline Materiel & $3(d)(2)$ & \begin{tabular}{|l|} 
Energy \\
Land \\
Well-being \\
Waste
\end{tabular} & \\
\hline Readiness & $3(d)(3)$ & Land & \\
\hline Human Capital & $3(d)(4)$ & Well-being & \\
\hline $\begin{array}{l}\text { Services and Infrastruc- } \\
\text { ture }\end{array}$ & $3(d)(5)$ & $\begin{array}{l}\text { Water } \\
\text { Land } \\
\text { Well-being }\end{array}$ & \\
\hline Soldier Health & $3(d)(6)$ & Well-being & \\
\hline
\end{tabular}




\begin{tabular}{|c|c|c|c|}
\hline $\begin{array}{l}\text { Area of Coordination and } \\
\text { Execution }\end{array}$ & ASCP Reference & $\begin{array}{l}\text { Topically } \\
\text { Relevant CERL } \\
\text { Indicator }\end{array}$ & $\begin{array}{l}\text { Specified } \\
\text { Metric }\end{array}$ \\
\hline \multicolumn{4}{|l|}{ Outcomes } \\
\hline Doctrine & $3(c)(2)$ & & \\
\hline $\begin{array}{l}\text { Sustainable Services } \\
\text { and Infrastructure }\end{array}$ & $3(c)(3)$ & $\begin{array}{l}\text { Water } \\
\text { Land } \\
\text { Well-being } \\
\text { Waste }\end{array}$ & \\
\hline $\begin{array}{l}\text { Improved utilization of } \\
\text { resources }\end{array}$ & $3(c)(4)$ & $\begin{array}{l}\text { Water } \\
\text { Energy } \\
\text { Land } \\
\text { Well-being } \\
\text { Waste }\end{array}$ & \\
\hline Continued access & $3(c)(5)$ & $\begin{array}{l}\text { Water } \\
\text { Land }\end{array}$ & \\
\hline $\begin{array}{l}\text { Enhanced operational } \\
\text { capability }\end{array}$ & $3(c)(6)$ & $\begin{array}{l}\text { Water } \\
\text { Energy } \\
\text { Land } \\
\text { Well-being } \\
\text { Waste }\end{array}$ & \\
\hline Enhanced well-being & $3(c)(7)$ & 6 & \\
\hline $\begin{array}{l}\text { Continued protection of } \\
\text { human health and envi- } \\
\text { ronment }\end{array}$ & $3(c)(8)$ & $\begin{array}{l}\text { Water } \\
\text { Energy } \\
\text { Land } \\
\text { Well-being }\end{array}$ & \\
\hline $\begin{array}{l}\text { Compliance and adapta- } \\
\text { bility }\end{array}$ & $3(c)(9)$ & $\begin{array}{l}\text { Water } \\
\text { Energy } \\
\text { Land } \\
\text { Well-being } \\
\text { Waste }\end{array}$ & \\
\hline
\end{tabular}




\section{Appendix B: Installation Strategic Sustainability Planning (ISSP) Summary}

The Installation Strategic Sustainability Planning (ISSP) process represents an important investment, and while it began as an installationlevel effort, it has done much to improve sustainability throughout the Army. The following pages summarize the ISSP goals of 22 installations, along with any available information of how the installation revisits, updates, or measures progress toward their goals. 


\begin{tabular}{|l|l|l|l|l|l|}
\hline INSTALLATION & \multicolumn{4}{|l|}{ Anniston Army Depot } \\
\hline $\begin{array}{l}\text { GOALS IN USE } \\
\text { (YES/NO): }\end{array}$ & YES & $\begin{array}{l}\text { GOALS } \\
\text { DEVELOPED }\end{array}$ & 2008 & $\begin{array}{l}\text { GOALS LAST } \\
\text { UPDATED }\end{array}$ & $\begin{array}{l}\text { Update scheduled } \\
\text { Dec } 2010\end{array}$ \\
\hline
\end{tabular}

Currently decentralized - Goal Champions responsible for all tracking and reporting. To be revised with integration into Strategic Plan.

\section{CURRENT SUSTAINABILITY GOALS:}

\section{INDUSTRIAL GOALS:}

- Integrated production equipment operation and maintenance

- Integrate sustainable practices using best achievable technology (BAT)

- A Sustainability Culture Throughout the ANAD Community

\section{COMPETITIVE EDGE GOALS:}

- Expand ANAD's relationship with the community to foster economic growth and stability. Participate in local resource planning to optimize resource availability for all stakeholders

- Sustain FY07 sales by diversifying our mission capabilities through partnerships to sustain existing workforce and developing innovative (non-traditional) business relationships with industry

\section{INFRASTRUCTURE GOALS:}

- Zero production line down time due to delay in parts delivery through improved intra-depot movement of supplies, services, and increased delivery efficiency

- Flexible and adaptable facilities: provide the right buildings at the right time in the right location to support current and future missions

- Become capable of $100 \%$ self-sufficient utility production over 2010 baseline (produced on depot or purchased within the local community). Utilities include water and energy (facility and mobility)

- Procurement and Contracting GOALS:

- Life-Cycle Sustainability - Change procurement strategy to...

- Influence weapons systems design and development (DMWR)

- Use performance based contracting to apply sustainability criteria to the acquisition of Goods, products, and materials; Equipment and processes (i.e., how we clean parts); Services and utilities

- Generate zero waste
CURRENT MEASUREMENTS FOR GOALS:

Measure progress at the objective level - measure not provided. 


\begin{tabular}{|c|c|c|c|c|c|}
\hline \multirow{2}{*}{\begin{tabular}{|l} 
INSTALLATION \\
GOALS IN USE \\
(YES/NO):
\end{tabular}} & \multicolumn{5}{|c|}{ USAG Baumholder } \\
\hline & Yes & $\begin{array}{l}\text { GOALS } \\
\text { DEVELOPED }\end{array}$ & 2008 & $\begin{array}{l}\text { GOALS LAST } \\
\text { UPDATED }\end{array}$ & Sept 2009 \\
\hline \multicolumn{3}{|c|}{ CURRENT SUSTAINABILITY GOALS: } & \multicolumn{3}{|c|}{ CURRENT MEASUREMENTS FOR GOALS: } \\
\hline \multicolumn{3}{|c|}{$\begin{array}{l}\text { - Well-zoned Community with Modern, Inte- } \\
\text { grated, and Maintainable Facilities } \\
\text { - } \quad \text { Zero-Footprint Baumholder (ZFB) } \\
\text { Innovative, Sustainable, and Effective Ser- } \\
\text { vices }\end{array}$} & \multicolumn{3}{|c|}{$\begin{array}{ll}\text { - } & \text { Energy consumption } \\
\text { - } & \text { Water consumption } \\
\text { - } & \text { Progreum use } \\
& \text { and new construction } \\
\text { - } & \text { Lean Six Sigma cost savings }\end{array}$} \\
\hline
\end{tabular}




\begin{tabular}{|l|l|l|l|l|l|}
\hline INSTALLATION & \multicolumn{4}{l|}{ Fort Benning } \\
\hline $\begin{array}{l}\text { GOALS IN USE } \\
\text { (YES/NO): }\end{array}$ & YES & $\begin{array}{l}\text { GOALS } \\
\text { DEVELOPED }\end{array}$ & 2005 & $\begin{array}{l}\text { LAST } \\
\text { UPDATED }\end{array}$ & March 2009 \\
\hline
\end{tabular}

The 5-year sustainability plan is integrated with the Garrison Strategic Plan; both plans are on a one year review cycle. http:// www.benning.army.mil/garrison/sustainability/

\section{CURRENT SUSTAINABILITY GOALS:}

REGIONAL INTERACTION

- Goal \#1 A Chattahoochee Valley community that sustains the Fort Benning mission, enhances quality of life, and protects and restores the environment will better serve the overall objectives.

\section{MILITARY TRAINING}

- Goal \#1: Increase Training Space (air, land, water, and bandwidth) by $50 \%$.

- Goal \#2: Fort Benning becomes the Army LiveVirtual-Constructive (LVC) Center of Excellence for J oint and Combined Arms Operations.

- Goal \#3: Establish world's most innovative Maneuver Center of Excellence

\section{INSTALLATION MANAGEMENT}

- Goal \#1: Achieve procurement of $100 \%$ sustainable goods and services by establishing an effective procurement network that minimizes life cycle costs, maximizes acquisition options, reduces delays, and establishes system-wide accountability and ownership

- Goal \#2: Fort Benning leads DoD in the provision of Soldier and Family Support Services

- Goal \#3: Capture full economic potential for energy efficiency through the use of innovative and sustainable approaches to energy acquisition, management and consumption

- Goal \#4: Implement sustainable water acquisition, use, and management practices that support the mission of Fort Benning

- Goal \#5: Facilities at Fort Benning meet sustainability objectives.

\section{POWER PROJ ECTION}

- Goal \#1: Increase deployment capacity and decrease deployment time for brigade elements by 2030 to $25 \%$ of FORSCOM standards.

- Goal \#2: Eliminate frustrated cargo and de-
CURRENT MEASUREMENTS FOR GOALS:

Progress measured at the objective level:

\section{COMMUNITY}

- Acres Under Conservation/ Non-development Easement

- Degree of designated lands in compatible use. Acres in various compatible land uses.

- Programs for Skills Management and Lifelong Learning (Percent target completion for LEAN Six Sigma Training)

\section{MISSION}

- High Performance (SPIRIT and LEED) Base Realignment and Closure Construction Expenditure (\$ millions)

- Solider Training Load (total number of Soldiers)

- Interactive Customer Evaluation Measures of Effectiveness (\%)

- Interactive Customer Evaluation Response Rate (\%)

- Strategic Sustainability Actions (Percent ongoing or completed)

- Number of usable live fire/ maneuver acres

- Number of usable multi-purpose live fire ranges

- Number of UXO acres

- Number of degraded acres rehabilitated

- Throughput and range utilization rate

- Training capacity for riverine and airborne operations

- Availability rate - percent of live fire/maneuver acres in suitable condition for scheduling/ use

- Utilization rate - percent use of scheduled resources

- Amount of resource "down time"

- Range and training area throughput rates

- Amount of space converted or restored to training use (e.g. redesignated or restored land)

- Range Readiness Review System data (share point document system)

- Incorporate use of sustainable technologies in all Initial Capabilities Documents (ICDs) and Capabilities Development Documents (CDDs). 


\begin{tabular}{|c|c|}
\hline $\begin{array}{l}\text { crease deployment time through reduction and } \\
\text { improved management of HAZMAT on the in- } \\
\text { stallation and during deployment }\end{array}$ & 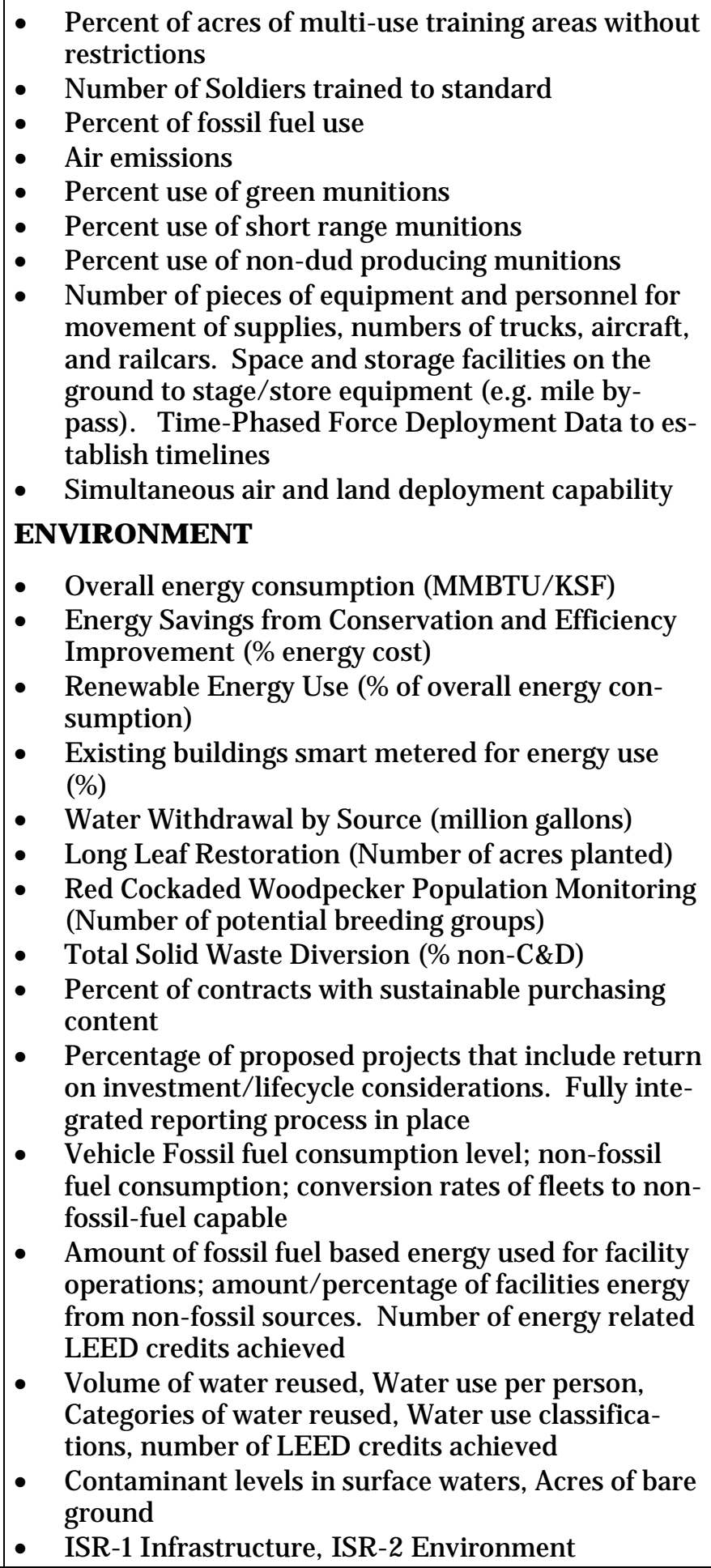 \\
\hline
\end{tabular}




\begin{tabular}{|c|c|c|c|c|c|}
\hline INSTALLATION & Fort Bragg & & & & \\
\hline $\begin{array}{l}\text { GOALS IN USE } \\
\text { (YES/NO): }\end{array}$ & $\begin{array}{l}\text { Yes (Goal } 1 \text { of } \\
\text { Strategic Plan) }\end{array}$ & $\begin{array}{l}\text { GOALS } \\
\text { DEVELOPED }\end{array}$ & 2000 & $\begin{array}{l}\text { LAST } \\
\text { UPDATED }\end{array}$ & $\begin{array}{l}\text { Annually, Sept } \\
2010\end{array}$ \\
\hline
\end{tabular}

Sustainability goals are linked to Goal 1 of the Garrison Strategic Plan. Strategic Plan Goal 1 managed by sustainability management council, reported to Senior Management Board. Objectives and projects under sustainability goals managed through EQCC and DPW.

\section{CURRENT SUSTAINABILITY GOALS:}

1.1 Land Use: Create and enhance sustainable training and urban areas to ensure military readiness and promote compatible growth of the surrounding communities.

1.2 Facilities: To become the model sustainable military community of the world by using sustainable principles throughout the life cycle of all facilities and supporting infrastructure (FSI).

1.3 Materials/ Commodities: Achieve zero waste through acquisition and management of materials and commodities, which, throughout their lifecycle, creates no additional waste nor requires resources for disposal.

1.4 Utilities: Supply reliable utility services and infrastructure with no negative impact while aggressively reducing overall demand. Utilities include energy, water, and information technology.

1.5 Transportation: Build a sustainable worldclass ground transportation network providing seamless transition between multiple modes of travel while reducing harmful emissions.

\section{CURRENT MEASUREMENTS FOR GOALS:}

Some have gross indicators of progress.

1.2 - number of high performance buildings on post

1.3 - normalized waste generation rates

1.4 - normalized energy use and cost of energy

Others measured at the objective level 


\begin{tabular}{|l|l|l|l|l|l|}
\hline INSTALLATION & \multicolumn{4}{|l|}{ Fort Campbell } \\
\hline $\begin{array}{l}\text { GOALS IN USE } \\
\text { (YES/NO): }\end{array}$ & YES & $\begin{array}{l}\text { GOALS } \\
\text { DEVELOPED }\end{array}$ & 2003 & $\begin{array}{l}\text { LAST } \\
\text { UPDATED }\end{array}$ & 2010 \\
\hline
\end{tabular}

Managed through Strategic Plan. Progress reported through the Installation Planning Board to the Senior Executive Leadership Committee. The review cycle is $2 \mathrm{x}$ per fiscal year, with the metrics set up for quarterly reporting. The specific initiatives within Objective P2 are managed through SIMS (EMS + sustainability management system)

\section{CURRENT SUSTAINABILITY GOALS:}

C2.4 Obtain Training Maneuver Area per Range Training Land Program-Development Plan

P2.1 Implement Sustainable Installation Management -ISO 14001

P2.2 Implement Sustainable Facilities

P2.3 Expand Use of Renewable Energy

P2.4 Execute Encroachment Prevention Strategy

P2.5 Sustainable Technology Demonstration Projects

P2.6 Initiate Affirmative Procurement Program (APP) (Green Procurement)

\section{CURRENT MEASUREMENTS FOR GOALS:}

Measures are at Objective or Initiative level:

- Evaluate available land vs. DPTMS requirements

- Conformance with International Organization for Standardization (ISO) 14001

- Potable water usage

- Projects (New Construction) implemented to meet 2 points for LEED to support reduction of impact on Municipal Separate Storm Sewer System (MS4)

- Percent of Stream Bank Restoration projects completed

- Percent of Construction and Demolition (C\&D) Waste diverted from landfill

- Percent of Municipal Solid Waste (MSW) diverted from landfill

- Percent reduction in hazardous waste generation

- Number of tons removed annually (Clean up training ranges)

- Percent of Military Construction (MILCON) buildings constructed annually with LEED "Silver" rating or better

- Percent of other (non-MILCON) buildings constructed annually having LEED "Silver" or better rating

- Number new transportation projects identified and funded by non-FTC sources

- Percent reduction in energy intensity (mbtu/ ksf)

- Percent increase in renewable energy use

- Funding Received for Army Compatible Use Buffer (ACUB) program annually

- Percent of designated "High-priority" (Zone 1) ACUB areas protected (6K acres around airfields)

- Percent of J LUS recommendations implemented by surrounding jurisdictions

- Percent of incompatible land use (urban encroachment) within designated high noise zones/APZs

- Number of FTC projects in planning, execution, or completed in current FY using other people's money

- Percent of directorates having established green procurement procedures that comply with EO13423 


\begin{tabular}{|c|c|c|c|c|c|}
\hline \multirow{2}{*}{\begin{tabular}{|l} 
INSTALLATION \\
GOALS IN USE \\
(YES/NO):
\end{tabular}} & \multicolumn{5}{|c|}{ Fort Carson } \\
\hline & Yes & $\begin{array}{l}\text { GOAS } \\
\text { DEVELOPED }\end{array}$ & 2002 & $\begin{array}{l}\text { LAST } \\
\text { UPDATED }\end{array}$ & May 2010 \\
\hline \multicolumn{6}{|c|}{$\begin{array}{l}\text { Sustainability is overseen through the Sustainability Management System which applies an EMS-like } \\
\text { framework to installation-wide sustainability }\end{array}$} \\
\hline \multicolumn{3}{|c|}{ CURRENT SUSTAINABILITY GOALS: } & \multicolumn{3}{|c|}{ CURRENT MEASUREMENTS FOR GOALS: } \\
\hline \multicolumn{3}{|c|}{$\begin{array}{l}\text { Sustainable Training Lands: Training ranges; } \\
\text { maneuver lands; and associated air space capa- } \\
\text { ble of supporting current and future military } \\
\text { training to standard while maintaining and sus- } \\
\text { taining training resources. } \\
\text { Energy and Water Resources: Sustain all facility } \\
\text { and mobility systems from renewable sources } \\
\text { and reduce total water purchased from outside } \\
\text { sources by } 75 \% \text { by } 2027 \text {. } \\
\text { Sustainable Development: Create a community } \\
\text { that encourages social, civic, and physical activi- } \\
\text { ty while protecting the environment. }\end{array}$} & \multicolumn{3}{|c|}{ 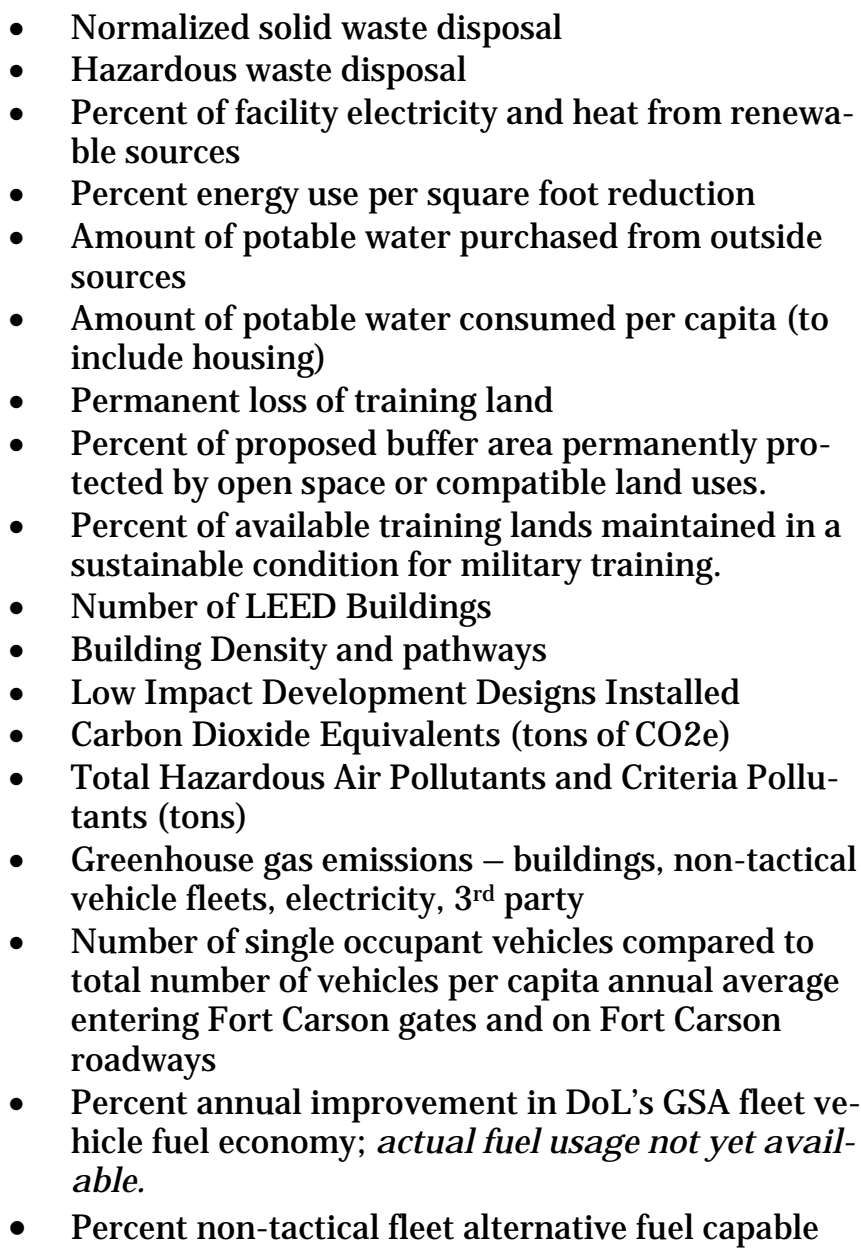 } \\
\hline
\end{tabular}




\begin{tabular}{|c|c|c|c|c|c|}
\hline \multirow{2}{*}{$\begin{array}{l}\text { INSTALLATION } \\
\text { GOALS IN USE } \\
\text { (YES/NO): }\end{array}$} & \multicolumn{5}{|c|}{ Fort Drum } \\
\hline & YES & $\begin{array}{l}\text { GOALS } \\
\text { DEVELOPED }\end{array}$ & 2008 & $\begin{array}{l}\text { LAST } \\
\text { UPDATED }\end{array}$ & $\begin{array}{l}\text { J un 2009. Currently } \\
\text { under review to incor- } \\
\text { porate IMCP V2 }\end{array}$ \\
\hline \multicolumn{3}{|c|}{ CURRENT SUSTAINABILITY GOALS: } & \multicolumn{3}{|c|}{ CURRENT MEASUREMENTS FOR GOALS: } \\
\hline \multicolumn{3}{|c|}{$\begin{array}{l}\text { We have been thru the ISSP Process (Jan 09) and } \\
\text { each of our goals in our Strategic Plan has Sustai- } \\
\text { nability embedded in them. We do not have sepa- } \\
\text { rate Sustainability Goals. }\end{array}$} & \multicolumn{3}{|c|}{ Measure progress at the objective level } \\
\hline \multicolumn{3}{|c|}{$\begin{array}{l}\text { We are currently incorporating the IMCP V2 as } \\
\text { the Base for our Strategic Plan, which will involve } \\
\text { retaining some of our previous objectives that do } \\
\text { not crosswalk to the IMCP, as Supporting Strateg- } \\
\text { ic Actions to the re-written Strategic Plan. }\end{array}$} & \multirow{9}{*}{\multicolumn{3}{|c|}{ Currently under review to incorporate IMCP V2 }} \\
\hline \multicolumn{3}{|c|}{ Current Strategic Goals: } & & & \\
\hline \multicolumn{3}{|c|}{$\begin{array}{l}\text { GOAL 1: A high performing, well-led, affordable } \\
\text { workforce of the proper size that is technically } \\
\text { competent, agile, motivated, knowledgeable, and } \\
\text { postured to meet the challenges of today's and } \\
\text { tomorrow's missions. }\end{array}$} & & & \\
\hline \multicolumn{3}{|c|}{$\begin{array}{l}\text { GOAL 2: Realistic training capabilities that optim- } \\
\text { ize installation and regional resources (land, air- } \\
\text { space, water and facilities) for current and future } \\
\text { missions }\end{array}$} & & & \\
\hline \multicolumn{3}{|c|}{$\begin{array}{l}\text { GOAL 3: Infrastructure self-sufficiency, including } \\
\text { on-post renewable sources of energy }\end{array}$} & & & \\
\hline \multicolumn{3}{|c|}{$\begin{array}{l}\text { GOAL 4: Optimal infrastructure growth through } \\
\text { community partnerships, use of emerging con- } \\
\text { struction and reclamation technologies, and sus- } \\
\text { tainable natural resources utilization }\end{array}$} & & & \\
\hline \multicolumn{3}{|c|}{$\begin{array}{l}\text { GOAL 5: An installation organized and structured } \\
\text { with adequate manning, equipment and facilities } \\
\text { to sustain the transformed tactical force with the } \\
\text { capability to anticipate future force requirements } \\
\text { and the ability to rapidly adapt to emerging tech- } \\
\text { nologies and changes to force structure and doc- } \\
\text { trine. }\end{array}$} & & & \\
\hline \multicolumn{3}{|c|}{$\begin{array}{l}\text { GOAL 6: Fort Drum and region's quality of life } \\
\text { makes it the installation of choice }\end{array}$} & & & \\
\hline \multicolumn{3}{|c|}{$\begin{array}{l}\text { GOAL 7: Efficient, effective, and responsive busi- } \\
\text { ness practices that optimize changing resources } \\
\text { for current and future missions. }\end{array}$} & & & \\
\hline
\end{tabular}




\begin{tabular}{|c|c|c|c|c|c|}
\hline \multirow{2}{*}{\begin{tabular}{|l} 
INSTALLATION \\
GOALS IN USE \\
(YES/NO):
\end{tabular}} & \multicolumn{5}{|l|}{ Fort Eustis } \\
\hline & $\begin{array}{l}\text { Yes - installa- } \\
\text { tion is transi- } \\
\text { tioning to a } \\
\text { J oint Base run } \\
\text { by the Air } \\
\text { Force }\end{array}$ & $\begin{array}{l}\text { GOALS } \\
\text { DEVELOPED }\end{array}$ & 2004 & LAST UPDATED & 2007 \\
\hline \multicolumn{3}{|c|}{ CURRENT SUSTAINABILITY GOALS: } & \multicolumn{3}{|c|}{$\begin{array}{l}\text { CURRENT MEASUREMENTS FOR } \\
\text { GOALS: }\end{array}$} \\
\hline \multicolumn{3}{|c|}{$\begin{array}{ll}\text { - } & \text { Achieve zero waste disposal; } \\
\text { - } & \text { Reduce dependency on fossil fuels; } \\
\text { - } & \text { Build a sustainable infrastructure; } \\
\text { - } & \text { Build energy efficient facilities; } \\
\text { - } & \text { Build forward-looking information technology in- } \\
& \text { frastructure. }\end{array}$} & \multicolumn{3}{|c|}{$\begin{array}{l}\text { Integrated into the installation strategic plan in } \\
\text { 2007. Sustainability goals became objectives. } \\
\text { Track progress in accomplishing specific projects } \\
\text { but not goals/ objectives overall. Have begun } \\
\text { some gross monitoring for specific resources } \\
\text { (water and power consumption) }\end{array}$} \\
\hline
\end{tabular}




\begin{tabular}{|c|c|c|c|c|c|}
\hline \multirow{2}{*}{$\begin{array}{l}\text { INSTALLATION } \\
\text { GOALS IN USE } \\
\text { (YES/NO): }\end{array}$} & \multicolumn{5}{|c|}{ Fort Greely } \\
\hline & NO & $\begin{array}{l}\text { GOALS } \\
\text { DEVELOPED }\end{array}$ & 2009 & $\begin{array}{l}\text { LAST } \\
\text { UPDATED }\end{array}$ & March 2010 \\
\hline \multicolumn{3}{|c|}{ CURRENT SUSTAINABILITY GOALS: } & \multicolumn{3}{|c|}{ CURRENT MEASUREMENTS FOR GOALS: } \\
\hline $\begin{array}{l}\text { Goal 1: Comprehens } \\
\text { Ft. Greely's workfor } \\
\text { cruitment, retention } \\
\text { ment of human reso } \\
\text { Goal 2: Our strategi } \\
\text { benchmark for intec } \\
\text { programming which } \\
\text { and future users. } \\
\text { Goal 3: Arctic bencl } \\
\text { structure and utiliti } \\
\text { and future mission r } \\
\text { gy efficiency and sel } \\
\text { environmental stew } \\
\text { Goal 4: Agile and st } \\
\text { pabilities that suppc } \\
\text { gencies, Fort Greely } \\
\text { vulnerabilities, impa } \\
\text { Goal 5: Progressive } \\
\text { unified partnerships } \\
\text { on optimizing resou } \\
\text { munication and sust }\end{array}$ & $\begin{array}{l}\text { velife } \\
\text { e nee } \\
\text { and } \\
\text { urces. } \\
\text { c plan } \\
\text { rated } \\
\text { meet } \\
\text { mark } \\
\text { s that } \\
\text { equire } \\
\text {-suffi } \\
\text { rdshi } \\
\text { te-of- } \\
\text { rt tod } \\
\text { After- } \\
\text { cts, ar } \\
\text { plann } \\
\text { captu } \\
\text { ces th } \\
\text { ainab }\end{array}$ & $\begin{array}{l}\text { le management of } \\
\text { lat address re- } \\
\text { essional develop- } \\
\text { will be the } \\
\text { ison planning and } \\
\text { needs of current } \\
\text { nodernized infra- } \\
\text { vide for current } \\
\text { ts to attain ener- } \\
\text { y while ensuring } \\
\text { art Logistics ca- } \\
\text { Mission, contin- } \\
\text {; while reducing } \\
\text { nstraints. } \\
\text { hat embraces } \\
\text { a future focused } \\
\text { gh accurate com- } \\
\text { hnoloov }\end{array}$ & $\begin{array}{l}\text { Goal } 1 \\
\text { Goal } 2 \\
\text { Goal } 3 \\
\text { energs } \\
\text { on the } \\
\text { Goal } 4 \\
\text { Goal } 5\end{array}$ & $\begin{array}{l}\text { Percent } \\
\text { of buildings be } \\
\text { divided by tot }\end{array}$ & $\begin{array}{l}\text { ly has had issues } \\
\text { rements. While } \\
\text { done in each area } \\
\text { tainability goals } \\
\text { als are being meas- }\end{array}$ \\
\hline
\end{tabular}




\begin{tabular}{|l|l|l|}
\hline INSTALLATION & \multicolumn{2}{|l|}{ USAG Hohenfels } \\
\hline $\begin{array}{l}\text { GOALS IN USE } \\
\text { (YES/NO): }\end{array}$ & Yes & $\begin{array}{l}\text { GOALS } \\
\text { DEVELOPED }\end{array}$ \\
\hline CURRENT SUSTAINABILITY GOALS: \\
\hline - USAG Hohenfels is a "Net Zero Bootprint”
\end{tabular}
Installation in terms of energy, water, materials, transportation, and waste/ emissions

- High performance, optimally-placed infrastructure that best supports the mission and community, while maximizing resources and adapting to change:

- Plan/ program

- Strategic Master Plan (zoning, development, time-phased execution strategy, investment strategy)

- Marketing/ resource acquisition

- Design/construct: High performing, re source efficient, sustainable building design

- Operate/maintain

- Adapt

- Maximize socialization opportunities through vibrant programming in modern and high-performing facilities.

- Ensure the Hohenfels community is safe and secure in a fluid environment by embracing technology and host nation relationships

- Technology (deterrence, detection, surveillance)

- Consolidated Incident Response Center (CIRC)

- Training Center (incident response, fire protection, law enforcement, safety)

- Develop sustainable community to support future missions by bringing family housing closer to installation, improving two-way communication between U.S. and HN communities, consolidating on-post retail services and enhancing medical care.

- Develop a Human Capital System that maximizes the intellectual capacity of the workforce, leverages resources to ensure sustainment of qualified employees, and transforms the culture of USAG-H into a model people-focused organization.

\begin{tabular}{|l|l|l} 
March 2010 & $\begin{array}{l}\text { LAST } \\
\text { UPDATED }\end{array}$ & March 2010 \\
\hline
\end{tabular}

CURRENT MEASUREMENTS FOR GOALS:

Strategic Plan recently completed - just beginning implementation and working to integrate IMCP measures into their measurement scheme 


\begin{tabular}{|c|c|c|c|c|c|}
\hline \multicolumn{2}{|c|}{ INSTALLATION } & \multicolumn{4}{|c|}{ Fort Hood } \\
\hline $\begin{array}{l}\text { GOALS IN } \\
\text { USE } \\
\text { (YES/NO): }\end{array}$ & $\begin{array}{l}\text { Yes on regional } \\
\text { goals. Garrison } \\
\text { Goals are in Tran- } \\
\text { sition to Strategic } \\
\text { Plan }\end{array}$ & $\begin{array}{l}\text { GOALS } \\
\text { DEVELOPED }\end{array}$ & 2002 & $\begin{array}{l}\text { LAST } \\
\text { UPDATED }\end{array}$ & $\begin{array}{l}\text { Regional Goals } \\
2010\end{array}$ \\
\hline \multicolumn{3}{|c|}{$\begin{array}{l}\text { CURRENT (Active) SUSTAINABILITY } \\
\text { GOALS: }\end{array}$} & \multicolumn{3}{|c|}{ CURRENT MEASUREMENTS FOR GOALS: } \\
\hline \multicolumn{3}{|c|}{$\begin{array}{l}\text { Sustainability being integrated into EMS. Cur- } \\
\text { rently working on Regional sustainability goals: } \\
\text { Quality of Life: Visionary progressive leaders, } \\
\text { government and citizens that are change- } \\
\text { oriented and embrace the needs and values of } \\
\text { the community making Central Texas the most } \\
\text { desirable region. }\end{array}$} & \multicolumn{3}{|c|}{$\begin{array}{l}\text { Regional sustainability goals are evaluated by } \\
\text { each community at the objective level. Pro- } \\
\text { gram started in J anuary } 2010 \text { and has not ma- } \\
\text { tured to measurement yet. }\end{array}$} \\
\hline \multicolumn{3}{|c|}{$\begin{array}{l}\text { Sustainable Development/Land Use: Cen- } \\
\text { tral Texas will maintain the ability of Fort Hood } \\
\text { to train, deploy and sustain its mission by pro- } \\
\text { moting sustainable development of the Fort } \\
\text { Hood region through mixed-use development, } \\
\text { intermodal transportation networks, open } \\
\text { space, and economic development. }\end{array}$} & & & \\
\hline \multicolumn{3}{|c|}{$\begin{array}{l}\text { Materials and Resources: Maximize effi- } \\
\text { cient use of resources, including regional mate- } \\
\text { rials, renewable energy, water, and recycling } \\
\text { programs to benefit our environment \&econo- } \\
\text { my for present and future generations. }\end{array}$} & & & \\
\hline \multicolumn{3}{|c|}{$\begin{array}{l}\text { Sustainable Transportation Solutions: } \\
\text { Central Texas will have a sustainable multi- } \\
\text { modal transportation network. }\end{array}$} & & & \\
\hline \multicolumn{3}{|c|}{$\begin{array}{l}\text { Education and Outreach: Central Texas is } \\
\text { Educated for Sustainability. }\end{array}$} & & & \\
\hline
\end{tabular}




\begin{tabular}{|c|c|c|c|c|c|}
\hline \multirow{2}{*}{\begin{tabular}{|l|} 
INSTALLATION \\
GOALS IN USE \\
(YES/NO):
\end{tabular}} & \multicolumn{5}{|c|}{ USAG Hawaii } \\
\hline & Yes & $\begin{array}{l}\text { GOALS } \\
\text { DEVELOPED }\end{array}$ & 2007 & \begin{tabular}{|l} 
LAST \\
UPDATED
\end{tabular} & August 2009 \\
\hline \multicolumn{3}{|c|}{ CURRENT SUSTAINABILITY GOALS: } & \multicolumn{3}{|c|}{ CURRENT MEASUREMENTS FOR GOALS } \\
\hline \multicolumn{3}{|c|}{$\begin{array}{l}\text { - Sustain a predictable posture to gen- } \\
\text { erate trained and ready forces in sup- } \\
\text { port of all mission requirements. } \\
\text { - Mission accomplished now and in the } \\
\text { future while minimizing resource con- } \\
\text { sumption, maximizing output through } \\
\text { cost saving efficiencies, and increasing } \\
\text { use of sustainable/ renewable/ alterna- } \\
\text { tive resources, products and services. } \\
\text { - The QOL OPB will meet soldier and } \\
\text { family needs by providing oversight, } \\
\text { guidance, direction, and prioritization } \\
\text { to ensure sustainable, quality services, } \\
\text { facilities, infrastructure, and informa- } \\
\text { tion technology in support of the Gar- } \\
\text { rison's mission. } \\
\text { A safe and secure installation with ef- } \\
\text { fective security operations that allow } \\
\text { for a non-emergency, pre-911 envi- } \\
\text { ronment. }\end{array}$} & \multicolumn{3}{|c|}{$\begin{array}{l}\text { Measure progress at the objective level - } \\
\text { measure not provided. }\end{array}$} \\
\hline
\end{tabular}




\begin{tabular}{|c|c|c|c|c|c|}
\hline \multirow{2}{*}{$\begin{array}{l}\text { INSTALLATION } \\
\text { GOALS IN USE } \\
\text { (YES/NO): }\end{array}$} & \multicolumn{5}{|c|}{ Fort J ackson } \\
\hline & Yes & $\begin{array}{l}\text { GOALS } \\
\text { DEVELOPED }\end{array}$ & $\begin{array}{l}\text { Established in } \\
\text { 2006, not re- } \\
\text { vised since }\end{array}$ & $\begin{array}{l}\text { LAST } \\
\text { UPDATE } \\
\text { D }\end{array}$ & $\begin{array}{l}\text { Objectives and targets are } \\
\text { reviewed and revised an- } \\
\text { nually }\end{array}$ \\
\hline \multicolumn{3}{|c|}{ CURRENT SUSTAINABILITY GOALS: } & \multicolumn{3}{|c|}{ CURRENT MEASUREMENTS FOR GOALS: } \\
\hline \multirow{2}{*}{\multicolumn{3}{|c|}{$\begin{array}{l}\text { Military Training: } \\
\text { Goal 1: Increase training efficiency and } \\
\text { capacity. } \\
\text { Goal 2: Develop an effective system of } \\
\text { indicators to track quality of life for the } \\
\text { Ft J ackson community. }\end{array}$}} & \multirow{10}{*}{\multicolumn{3}{|c|}{$\begin{array}{l}\text { Measure progress at the objective level - } \\
\text { measure not provided. }\end{array}$}} \\
\hline & & & & & \\
\hline \multicolumn{3}{|c|}{$\begin{array}{l}\text { Goal 3: Establish an efficient, sustaina- } \\
\text { ble, and comprehensive installation } \\
\text { planning process that is commensurate } \\
\text { with the current operating environment } \\
\text { (COE) and future installation require- } \\
\text { ments. }\end{array}$} & & & \\
\hline \multicolumn{3}{|c|}{$\begin{array}{l}\text { Goal 4: Ensure optimal utilization of all } \\
\text { existing Fort J ackson lands for training } \\
\text { purposes. }\end{array}$} & & & \\
\hline \multicolumn{3}{|c|}{ Transportation: } & & & \\
\hline \multicolumn{3}{|c|}{$\begin{array}{l}\text { Goal 1: Use renewable energy sources } \\
\text { for all mobility systems to provide effi- } \\
\text { cient transportation of materials and } \\
\text { personnel. }\end{array}$} & & & \\
\hline \multicolumn{3}{|c|}{$\begin{array}{l}\text { Goal 2: Access-friendly and secure in- } \\
\text { stallation. }\end{array}$} & & & \\
\hline \multicolumn{3}{|l|}{ Procurement: } & & & \\
\hline \multicolumn{3}{|c|}{$\begin{array}{l}\text { Goal 1: Enhance current policies and } \\
\text { procedures to ensure a flexible and sus- } \\
\text { tainable procurement process to work } \\
\text { towards achieving zero waste. }\end{array}$} & & & \\
\hline \multicolumn{3}{|c|}{$\begin{array}{l}\text { Goal 2: A logistics system that ensures } \\
\text { optimum utilization of available re- }\end{array}$} & & & \\
\hline
\end{tabular}


sources.

\section{Infrastructure:}

Goal 1: Operate an integrated, sustainable water system.

Goal 2: Achieve 100\% energy selfsufficiency.

\section{Regional Interaction:}

Goal 1: Achieve sustainable, long-term economic development in the Fort J ackson region.

Goal 2: Integrated compatible regional land use.

Goal 3: An active regional recreational partnership with facilities/ activities that maximize community and military participation, well-being, revenue, fitness and promote active living. 


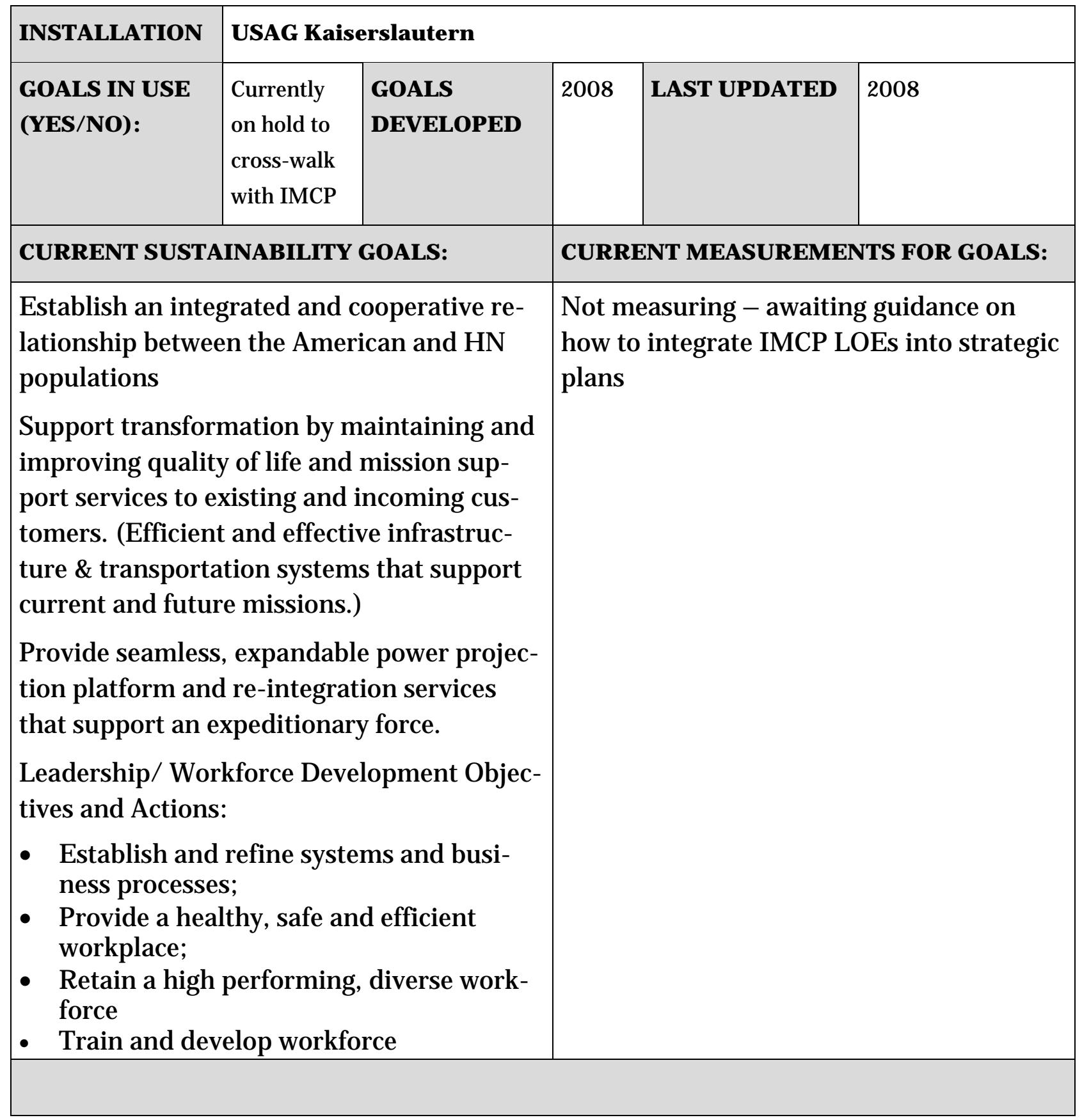




\begin{tabular}{|l|l|l|l|l|l|}
\hline INSTALLATION & \multicolumn{5}{|l|}{ Letterkenny Army Depot } \\
\hline $\begin{array}{l}\text { GOALS IN USE } \\
\text { (YES/NO): }\end{array}$ & YES & $\begin{array}{l}\text { GOALS } \\
\text { DEVELOPED }\end{array}$ & 2008 & $\begin{array}{l}\text { LAST } \\
\text { UPDATED }\end{array}$ & 2010 \\
\hline
\end{tabular}

Goals managed through the Depot Commander-chaired EQCC. Progress reviewed quarterly with Commander and Senior Staff. Progress reported and reviewed monthly within DPW.

\section{CURRENT SUSTAINABILITY GOALS:}

Goal 1: Water Conservation:

Establish a baseline for all water systems to include usage of potable water, waste water and storm water runoff by 2010

Conserve and reduce water usage for potable and non-potable water to include recycling of water for reuse

\section{Goal 2: Energy Conservation}

Develop and implement an energy conservation and reduction program to achieve energy sustainability

Supply all energy for depot operations from renewable resources by 2033

\section{Goal 3: Pollution Reduction:}

Achieve $100 \%$ diversion of solid waste (to include hazardous waste) from landfills or incinerators by 2033

No Title V Air Quality permit needed by 2018

\section{CURRENT MEASUREMENTS FOR GOALS:}

Goal 1:

- Overall water use from reservoir

- Wastewater discharge from the IWTP per direct man-hour

- Storm water flow and pollutants

Goal 2:

- Net energy consumption per direct labor hour

- Number and level of LEED Certified facilities

- Percentage of energy purchased from Green Sources

Goal 3:

- Percentage of wood diverted from landfills

- Amount of hazardous waste generated per direct labor hour

- Air pollutants from painting operations

- Air pollutants from OB/OD operations 


\begin{tabular}{|c|c|c|c|c|c|}
\hline \multirow{2}{*}{\begin{tabular}{|l|} 
INSTALLATION \\
$\begin{array}{l}\text { GOALS IN USE } \\
\text { (YES/NO): }\end{array}$
\end{tabular}} & \multicolumn{5}{|c|}{ Fort Leonard Wood } \\
\hline & YES & $\begin{array}{l}\text { GOALS } \\
\text { DEVELOPED }\end{array}$ & 2010 & $\begin{array}{l}\text { LAST } \\
\text { UPDATED }\end{array}$ & 2010 \\
\hline \multicolumn{3}{|c|}{ CURRENT SUSTAINABILITY GOALS: } & \multicolumn{3}{|c|}{ CURRENT MEASUREMENTS FOR GOALS } \\
\hline \multicolumn{3}{|c|}{$\begin{array}{l}\text { Goal 1: Enduring communities supported } \\
\text { by enhanced infrastructure and efficient } \\
\text { utilities }\end{array}$} & \multirow{7}{*}{\multicolumn{2}{|c|}{ Under development }} & \\
\hline Goal 2: Forecast & ng anc & Resourcing & & & \\
\hline $\begin{array}{l}\text { Goal 3: Organiz } \\
\text { adequate manni } \\
\text { and facilities to s } \\
\text { support of the tr } \\
\text { missions. }\end{array}$ & $\begin{array}{l}\text { and c } \\
\text { us, equ } \\
\text { ustain } \\
\text { aining }\end{array}$ & $\begin{array}{l}\text { istruct FLW with } \\
\text { ment, technology, } \\
\text { ission services in } \\
\text { d deployment }\end{array}$ & & & \\
\hline \multicolumn{3}{|c|}{$\begin{array}{l}\text { Goal 4: Full and Effective Community En- } \\
\text { gagement }\end{array}$} & & & \\
\hline \multicolumn{3}{|c|}{$\begin{array}{l}\text { Goal 5: Service Members, Families and Ci- } \\
\text { vilians Resilient in Mind, Body and Spirit. }\end{array}$} & & & \\
\hline \multicolumn{3}{|c|}{$\begin{array}{l}\text { Goal 6: FLW community utilizes employ- } \\
\text { ment services and educational opportuni- } \\
\text { ties }\end{array}$} & & & \\
\hline \multicolumn{3}{|c|}{$\begin{array}{l}\text { Goal 7: Modern, adaptable and high per- } \\
\text { formance training facilities, ranges and } \\
\text { land. }\end{array}$} & & & \\
\hline
\end{tabular}




\begin{tabular}{|c|c|c|c|c|c|}
\hline \multirow{2}{*}{\begin{tabular}{|l} 
INSTALLATION \\
GOALS IN USE \\
(YES/NO):
\end{tabular}} & \multicolumn{5}{|c|}{ Fort Lewis } \\
\hline & Yes & & 2002 & & 2007 \\
\hline \multicolumn{3}{|c|}{ CURRENT SUSTAINABILITY GOALS: } & \multicolumn{3}{|c|}{ CURRENT MEASUREMENTS FOR GOALS: } \\
\hline $\begin{array}{l}\text { Goal 1- Air Quality: } \\
\text { nary source and non } \\
\text { emissions } 85 \% \text { by } 2 \\
\text { Goals } 2 \& 3 \text { - Energy: } \\
\text { - Reduce total energ } \\
2015 \\
\text { - Sustain all activitie } \\
\text { energy sources and } \\
\text { post by } 2025 \\
\text { Goal } 4 \text { - Sustainable } \\
\text { tainable neighborho } \\
\text { community that enh } \\
\text { gion } \\
\text { Goal } 5 \text { - Products an } \\
\text { terial use to achieve } \\
\text { Goals } 6 \& 7 \text { - Sustain } \\
\text { - Maintain the abilit } \\
\text { current and future } \\
\text { compromising the ir } \\
\text { tural resources, botl } \\
\text { gionally. } \\
\text { - Recover all listed a } \\
\text { in the South Puget } \\
\text { Goal } 8 \text { - Water Reso } \\
\text { to Class A reclaim st } \\
\text { serve water resource } \\
\text { water quality }\end{array}$ & $\begin{array}{l}\text { Domm } \\
\text { ds for } \\
\text { nces t } \\
\text { Mate } \\
\text { ero ne } \\
\text { ole Tro } \\
\text { of For } \\
\text { litary } \\
\text { egrity } \\
\text { on the }\end{array}$ & $\begin{array}{l}\text { mstallation statio- } \\
\text { motor vehicle air } \\
\text { ption by } 30 \% \text { by } \\
\text { using renewable } \\
\text { all electricity on } \\
\text { ity: Create sus- } \\
\text { livable Fort Lewis } \\
\text { Puget Sound Re- } \\
\text { als: Cycle all ma- } \\
\text { waste by } 2025 \\
\text { ing Lands: } \\
\text { Lewis to meet its } \\
\text { issions without } \\
\text { f natural and cul- } \\
\text { astallation and re- } \\
\text { prove Puget Sound } \\
\text { date federal species } \\
\text { yion } \\
\text { reat all wastewaters } \\
\end{array}$ & $\begin{array}{l}\text { Goal } 1 \\
\text { - Stati } \\
\text { Goals } \\
\text { - Mege } \\
\text { to taro } \\
\text { - Perce } \\
\text { Goal } 4 \\
\text { - Perc } \\
\text { sign p } \\
\text { - Perc } \\
\text { per pr } \\
\text { Goal } 5 \\
\text { - Perc } \\
\text { Hazar } \\
\text { units } \\
398 \text { lo }\end{array}$ & $\begin{array}{l}\text { ce emissions } \\
\text { rics: } \\
\text { quare feet of fa } \\
\text { wable Energy } \\
\text { orhood attainn } \\
\text { nent of sustain } \\
\text { tial potential c } \\
\text { rial Control Ce } \\
\text { activities); De }\end{array}$ & $\begin{array}{l}\text { s space (reduction } \\
\text { fustainable de- } \\
\text { esign principles } \\
\text { to Puget Sound } \\
\text { ncludes military } \\
\text { Sites: Deliver to } \\
\text { ersion that use the } \\
\text { and diversion } \\
\text { training } \\
\text { ens for }\end{array}$ \\
\hline
\end{tabular}




\begin{tabular}{|c|c|c|c|c|c|}
\hline \multirow{2}{*}{$\begin{array}{l}\text { INSTALLATION } \\
\text { GOALS IN USE } \\
\text { (YES/NO): }\end{array}$} & \multicolumn{5}{|c|}{ Fort Riley } \\
\hline & YES & $\begin{array}{l}\text { GOALS } \\
\text { DEVELOPED }\end{array}$ & 2009 & $\begin{array}{l}\text { LAST } \\
\text { UPDATED }\end{array}$ & 2010 \\
\hline \multicolumn{3}{|c|}{ CURRENT SUSTAINABILITY GOALS: } & \multicolumn{3}{|c|}{ CURRENT MEASUREMENTS FOR GOALS: } \\
\hline \multicolumn{3}{|c|}{$\begin{array}{l}\text { - Ensure Ft. Riley's ability to meet its mission; } \\
\text { maintain the integrity of natural, cultural and } \\
\text { economic resources; and cooperate with neighbor- } \\
\text { ing communities in and around the Flint Hills Re- } \\
\text { gion. } \\
\text { - Fort Riley and the surrounding Flint Hills Region } \\
\text { is a community of choice for Soldiers, Families, } \\
\text { Retirees, and civilians - an enduring, welcoming, } \\
\text { Family-oriented community that consists of inter- } \\
\text { connected services: } \\
\text { o High quality jobs, } \\
\text { o Affordable housing, } \\
\text { o State of the art healthcare, } \\
\text { o Quality education, } \\
\text { o Affordable childcare, and } \\
\text { o Diverse recreational opportunities } \\
\text { - Recognized as the DoD Installation of Logistics } \\
\text { Excellence for its regional partnerships resulting } \\
\text { in efficient transportation and maintenance sys- } \\
\text { tems, responsive supply chain, and zero waste. } \\
\text { - Provide sustainable facilities, infrastructure and } \\
\text { land development to support the mission while } \\
\text { enhancing quality of life. } \\
\text { o Eliminate energy waste in existing facilities } \\
\text { o Increase energy efficiency in new construction } \\
\text { and renovations } \\
\text { o Eliminate dependence on fossil fuels } \\
\text { o Conserve water resources to achieve a sustaina- } \\
\text { ble level } \\
\text { o Improve energy security } \\
\text { o Development that addresses land use patterns, } \\
\text { transportation, utility infrastructure, and re- } \\
\text { gional collaboration } \\
\text { o Maintain historic value of Fort Riley } \\
\text { o Design, build, commission, maintain, decom- } \\
\text { mission sustainable facilities }\end{array}$} & \multicolumn{3}{|c|}{$\begin{array}{l}\text { Progress on Methods (Tasks/initiatives) is reported } \\
\text { weekly to the Senior Commander via email and a } \\
\text { VTC is conducted every } 6 \text { weeks for face-to-face re- } \\
\text { porting. Measures not provided. }\end{array}$} \\
\hline
\end{tabular}




\begin{tabular}{|c|c|c|c|c|c|}
\hline INSTALLATION & Fort Rucker & & & & \\
\hline $\begin{array}{l}\text { GOALS IN USE } \\
\text { (YES/NO): }\end{array}$ & $\begin{array}{l}\text { (Oct 2010) Still in } \\
\text { development of first } \\
\text { version of plan and } \\
\text { integration with } \\
\text { IMCOM campaign } \\
\text { plan }\end{array}$ & $\begin{array}{l}\text { GOALS } \\
\text { DEVELOPED }\end{array}$ & 2009 & $\begin{array}{l}\text { LAST } \\
\text { UPDATED }\end{array}$ & $\begin{array}{l}\text { Goals updated } \\
\text { April } 2010 . \\
\text { Action plans under } \\
\text { development }\end{array}$ \\
\hline
\end{tabular}

The Installation Planning Board (IPB), chaired by the senior commander and facilitated by the Garrison Commander, is the venue by which the installation's common operating picture is presented to installation senior leaders. The board is comprised of primary tenant activity commanders, school commandants and their sergeants major. The board serves as the principal forum by which senior leaders communicate with installation stakeholders and planners to:

- Present the broad continuum of results and decisions of numerous planning activities

- Demonstrate how installation activities interrelate and contribute to the spectrum of support for the Mission and our Soldiers and Families

- Communicate the Senior Commander's priorities

- Provide a final opportunity to ensure all significant inputs have been considered and synchronized Stakeholders, both internal and external, working in concert with the U.S. Army Aviation Center of Excellence and the Garrison, participate in functional boards and workgroups, such as the Real Property Planning Board, Safety, Well-being, Environmental, Anti-terrorism/Force Protection, Training/Readiness Support and the Installation Planning Board Steering Committee. These planning forums validate alignment of their functional products and initiatives with the senior commander's installation priorities and strategic plan. Updates on initiatives are presented semi-annually to the IPB, which in turn provides feedback and guidance on the installation's strategic direction.

\section{CURRENT SUSTAINABILITY GOALS:}

Goal 1: Enhance support to ARFORGEN and mission training

Goal 2: Sustain, Transform \& Modernize the Installation

Goal 3: Enhance Well-Being of the Military Community

Goal 4: Recruit, Develop and Sustain a ServiceOriented, Mission-Focused and Capable Workforce Goal 5: Transform Business Processes to Optimize Resources
CURRENT MEASUREMENTS FOR GOALS:

To be developed around IMCOM Campaign Plan LOE Metrics 


\begin{tabular}{|l|l|l|l|l|l|}
\hline INSTALLATION & \multicolumn{4}{|l|}{ USAG Vicenza } \\
\hline $\begin{array}{l}\text { GOALS IN USE } \\
\text { (YES/NO): }\end{array}$ & Yes & $\begin{array}{l}\text { GOALS } \\
\text { DEVELOPED }\end{array}$ & 2010 & $\begin{array}{l}\text { LAST } \\
\text { UPDATED }\end{array}$ & 2010 \\
\hline
\end{tabular}

CURRENT SUSTAINABILITY GOALS:

- Soldiers, Families and Civilians are able to meet the challenges of deployment and the ARFORGEN process through proper training, responsive services, and communities of excellence.

- Soldiers, Families, and Civilians are confident that they are being cared for; and their physical, emotional, and spiritual needs are enriched by quality programs, infrastructure, and support.

- A multi-skilled workforce comprising Military and Civilian leaders and personnel with the knowledge, capabilities, skills, and opportunities to successfully and innovatively accomplish the installation management mission.

- Installations are platforms of readiness supporting current and future requirements through regular modernization and new construction of facilities and infrastructure to maintain efficient and sustainable operations and to enable the provision of effective services to Soldiers, Families and Civilians.

- All Soldiers, Families, and Civilians consciously employ risk reduction measures to foster a safe working and living environment, instilling a sense of safety both on- and off-duty while promoting leader and individual accountability.

- Maintain energy and water efficient installations by holding users accountable, modernizing facilities, installing new technologies, and leveraging partnerships that will provide an increased level of energy security leading to sustainable and resilient infrastructure and mission assurance.

\section{CURRENT MEASUREMENTS FOR GOALS:}

Goals are the same as the IMCP LOE. Currently implementing strategic objectives and integrating IMCP measurement. 


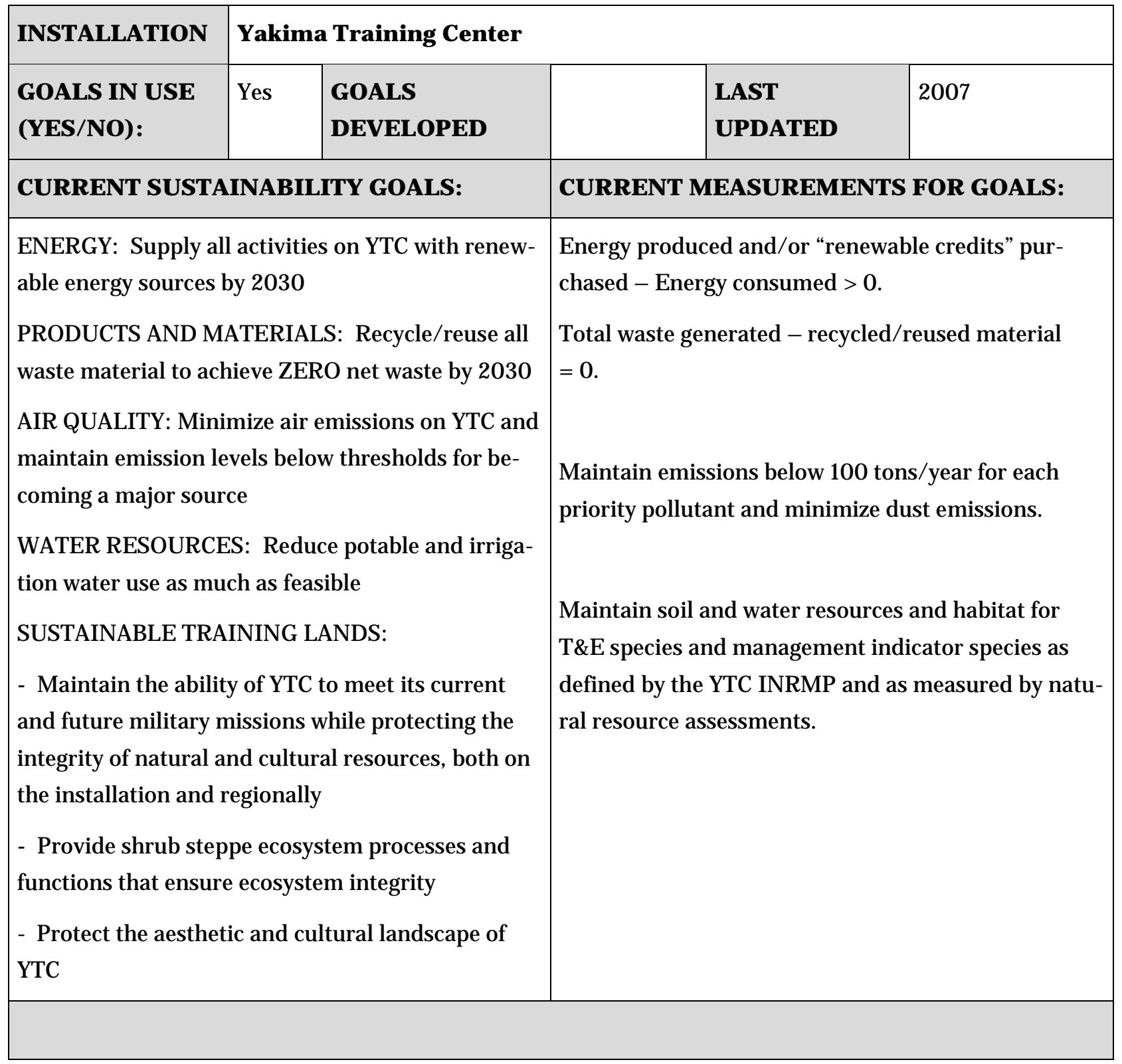




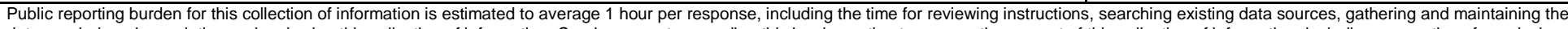

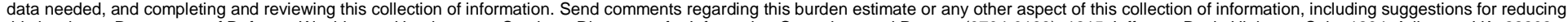

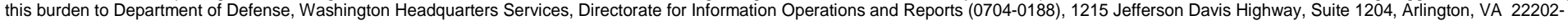

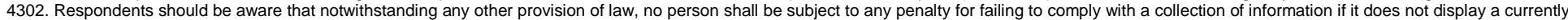
valid OMB control number. PLEASE DO NOT RETUR N YOUR FORM TO THE ABOVE ADDRESS.

\begin{tabular}{l|l} 
valid OMB control number. PLEASE DO NOT RETURN YOUR FORM TO THE ABOVE ADDRESS. \\
\hline 1. REPORT DATE (DD-MM-YYYY) & $\mathbf{2}$. REPOR
\end{tabular}

March 2011

Final Tech Report

4. TITLE AND SUBTITLE

Sustainability Indicators for the Army Installation Management Command

3. DATES COVERED (From - To)

5a. CONTRACT NUMBER

5b. GRANT NUMBER

5C. PROGRAM ELEMENT

6. AUTHOR(S)

Chris C. Rewerts, Michelle J. Hanson, David A. Krooks, Gary G. Gerdes, Michael R.

Kemme, and William T. Brown

5d. PROJ ECT NUMBER

5e. TASK NUMBER

5f. WORK UNIT NUMBER

BK4914

8. PERFORMING ORGANIZATION REPORT NUMBER

U.S. Army Engineer Research and Development Center (ERDC)

Construction Engineering Research Laboratory (CERL)

ERDC/ CERL TR-11-11

PO Box 9005

CHAMPAIGN IL 61826-9005

9. SPONSORING / MONITORING AGE NCY NAME(S) AND ADDRESS(ES)

Headquarters, Installation Management Command (HQIMCOM)

11711 N IH 35

SAN ANTONIO TX 78233

10. SPONSOR/MONITOR'S ACRONYM(S)

IMCOM

11. SPONSOR/MONITOR'S REPORT NUMBER(S)

12. DISTRIBUTION / AVAILABILITY STATE ME NT

Approved for public release; distribution is unlimited.

\section{SUPPLE ME NTARY NOTES}

14. ABSTRACT

This study addresses the nature of indicators of sustainability. Such indicators differ from both sustainability goals and plans, and even from the implementation of actions that are believed likely to enhance sustainability. The indicators developed during this study are intended as direct measures of sustainability. The attributes of ideal indicators of sustainability are discussed. A set of indicators is defined that satisfy the criteria represented by the attributes. This ideal set of indicators is then confronted with Army data that might be used to derive values for the indicators. A set of six indicators and data sources is proposed for use both by installations that are part of the U.S. Army's Installation Management Command (IMCOM) and by the Command itself.

\section{SUBJ ECT TERMS}

sustainability; sustainability indicators; US A rmy; IM COM ; CA SI

\begin{tabular}{|c|c|c|c|c|c|}
\hline 16. SECURITY CL & IFICATION OF: & & 17. LIMITATION & 18. NUMBER & 19a. NAME OF RESPONSIBLE PERSON \\
\hline $\begin{array}{l}\text { a. REPORT } \\
\text { Unclassified }\end{array}$ & $\begin{array}{l}\text { b. ABSTRACT } \\
\text { Unclassified }\end{array}$ & $\begin{array}{l}\text { c. THIS PAGE } \\
\text { Unclassified }\end{array}$ & UU & 112 & $\begin{array}{l}\text { 19b. TELEPHONE NUMBER } \\
\text { (include area code) }\end{array}$ \\
\hline
\end{tabular}

